Portland State University

PDXScholar

\title{
Engaging Communities in Archaeology on Private Property in an Urban Neighborhood: the Search for the First (1825-1829) Fort Vancouver, Vancouver, Washington
}

Amy Carolyn Clearman

Portland State University

Follow this and additional works at: https://pdxscholar.library.pdx.edu/open_access_etds

Part of the Anthropology Commons

Let us know how access to this document benefits you.

\section{Recommended Citation}

Clearman, Amy Carolyn, "Engaging Communities in Archaeology on Private Property in an Urban Neighborhood: the Search for the First (1825-1829) Fort Vancouver, Vancouver, Washington" (2020). Dissertations and Theses. Paper 5584.

https://doi.org/10.15760/etd.7456

This Thesis is brought to you for free and open access. It has been accepted for inclusion in Dissertations and Theses by an authorized administrator of PDXScholar. Please contact us if we can make this document more accessible: pdxscholar@pdx.edu. 
Engaging Communities in Archaeology on Private Property in an Urban Neighborhood:

The Search for the First (1825-1829) Fort Vancouver, Vancouver, Washington

\author{
by \\ Amy Carolyn Clearman
}

A thesis submitted in partial fulfillment of the requirements for the degree of

Master of Science

in

Anthropology

Thesis Committee:

Virginia Butler, Chair

Douglas Wilson

Jeremy Spoon

Portland State University

2020 


\begin{abstract}
Current archaeological literature calls for archaeology to become increasingly relevant in the modern world. Involvement in archaeological research can enhance the relevancy of archaeology for participants of public archaeology projects by strengthening personal connections with heritage and history. To investigate the impact of direct involvement in archaeological research on residents in Vancouver, Washington, I recruited members of two neighborhoods associated with Fort Vancouver National Historic Site to participate in the archaeological search for material remains of the first (1825-1829) Fort Vancouver. I asked the question: How does involvement in a public archaeology project affect participants' feelings about heritage, archaeology, and place attachment?
\end{abstract}

This project employed four methods. 1) Documentary research examined the history of the first Fort Vancouver and the project area. 2) Public outreach methods created community interest in the project, facilitated interactions between myself and community members, and aided in recruitment of participants. 3) Ethnographic methods included informational interviews with long-time area residents; ethnographic interviews with excavation participants to gauge impacts on feelings toward heritage, archaeology and place attachment; and surveys to collect the thoughts and views of the wider public. 4) Archaeological excavation with residents on private property searched for material remains of the first Fort Vancouver, as well as evidence of the history of the project area.

A combination of documentary, ethnographic, and archaeological evidence points to one section of the project area as the most likely location of the first Fort Vancouver. 
The history of the project area landscape is reflected in artifacts recorded across the project area during archaeological excavations. Precontact-era items signal the use of the land by Native American groups, mid- to late-19th-century artifacts identify a potential location of British occupation, and the large number of objects dating from the early 20th century to the present demonstrate the rapid growth and wide-spread development of the project area beginning around 1900.

Results from my ethnographic research suggest that knowledge of and direct involvement in a local archaeological project strengthens feelings in various communities of stakeholders toward heritage, archaeology, and place. Place attachment plays an important role in fostering place-based inclusion in area heritage and history. And connections to place and past people realized through involvement in archaeological research reveals the relevancy of this research to various communities of stakeholders. 


\title{
Dedication
}

To Joe Rabinowitz, my best friend and the most wonderful husband I could ever hope to have. This journey has been stressful, exhausting, and long, and your support has never wavered.

\section{In Memory of}

\author{
Neta Boss Linderman
}

1943-2019 


\section{Acknowledgements}

First, I thank Dr. Douglas Wilson. As my advisor and mentor, he guided me through the ups and downs of graduate school and never failed to give me encouraging support and honest feedback. When I came to him my first year of graduate school and said I wanted to do backyard archaeology, his eyes lit up as he announced that he had the perfect thing for me. I thank my committee members, Dr. Virginia Butler and Dr. Jeremy Spoon. Dr. Butler's enthusiasm for, interest in, and support of my project from the beginning has been incredibly encouraging. Dr. Spoon's teaching and guidance on ethnographic methods proved critical to the implementation and success of this project. I truly could not have accomplished this research without his instruction and advice.

I extend an enormous thank you to all of my project participants. These wonderful people were incredibly generous with their time, properties, thoughts, and feelings, and I cannot express my gratitude enough. They opened up their hearts and homes to me (even allowing me, covered in dirt from head to toe, to enter their homes to use the bathroom during excavation days), and were all remarkably encouraging, kind, and enthusiastic. Thank you all, so very, very much.

I thank David Ellis and the Wayne Suttles Fellowship committee. Your generous financial support allowed me to continue with and finish my thesis even throughout a sudden months-long family health crisis. This fellowship genuinely helped my family and me through a difficult time. I also thank the Newman Fund committee for their financial contribution which allowed me to travel to St. Louis, Missouri to present my work at the 2019 annual conference for the Society for Historical Archaeology. 
I send a huge thank you to everyone at Fort Vancouver National Historic Site for all of their support and help, especially Dr. Douglas Wilson, Tessa Langford, and Katie Wynia, and a special thank you to Elaine Dorset for sharing her research on the first fort with me. Also, I thank Mary Rose with the Friends of Fort Vancouver for her part in making my public presentations at the Visitors Center possible.

I thank the Clark County Historical Museum for allowing me to do research in the historical archives, and especially James William Kice for getting pictures of THE bottle to me so quickly.

Thank you to Carey Price at the Washington State School for the Deaf for showing me through the school's archives and helping me find what I was looking for.

I give a special thanks to Alex Gall and Justin Colón at Archaeological Services, LLC for their incredible generosity in sharing their work, reports, and artifacts with me related to their work in my project area. I appreciate it so much.

To my grad student friends, the lovely ladies as I call them, I am indebted for their friendship, support, and love. There is not another group of women I would rather have gone through this process with. I send a special thank you to Katie Tipton for our thesis work sessions and for always being ready with words of encouragement and helpful advice.

I appreciate my sisters Annie, Tara, and Julie, and my parents Carol and Bill Clearman for being my biggest fans and cheering me on with so much love.

Finally, to my husband, Joe Rabinowitz, and our daughters, Miette, Verity, and Melanie, a colossal thank you. The past few years have brought many joyful moments, 
and we have weathered many storms as a family. Throughout my grad school career we were rocked by the deaths of loved ones (Harvey and Rosie Rabinowitz, rest in peace), we welcomed into the world Asher my sweetie-pie grandson, we survived a cancer diagnosis and treatments (yay, Miette, you did it!), and we stood together through countless other joys and griefs, both large and small. Thank you all for being so amazing. I love you with all my heart. 


\section{Table of Contents}

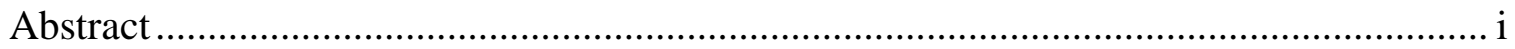

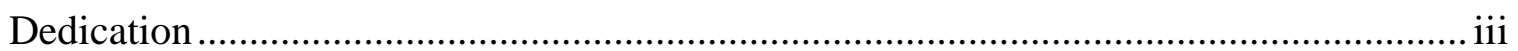

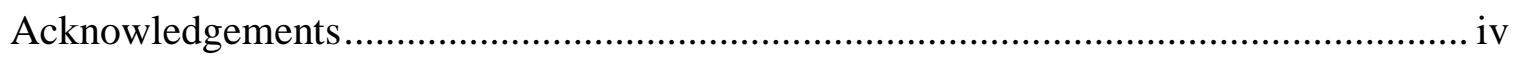

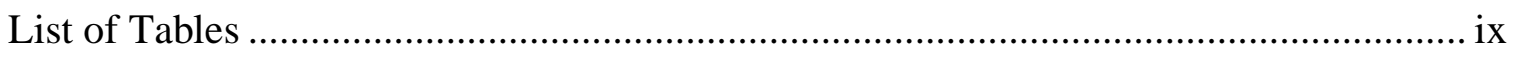

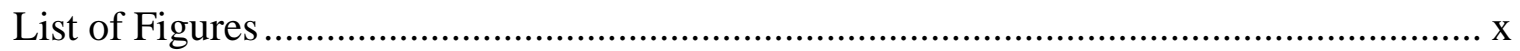

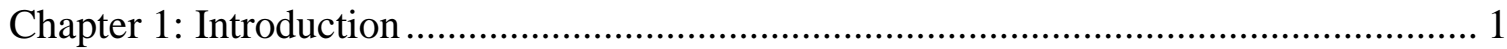

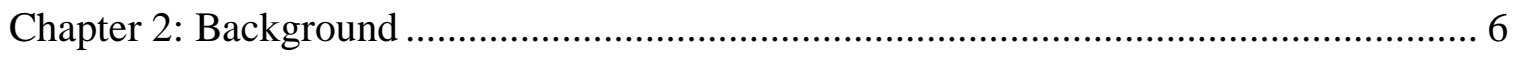

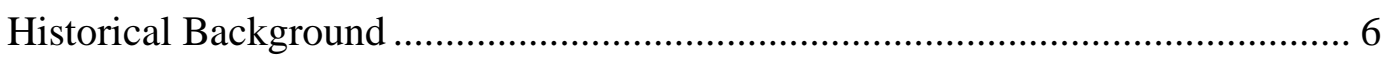

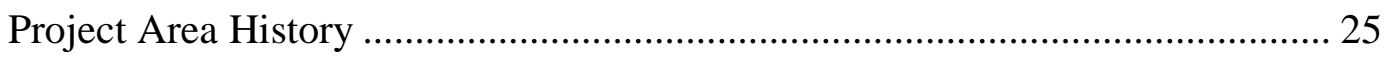

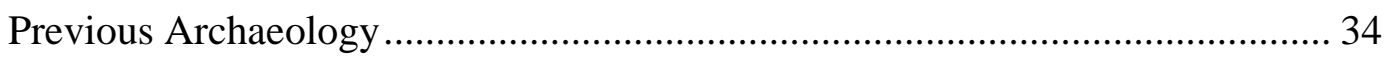

Chapter 3: Theoretical Approaches ......................................................................... 39

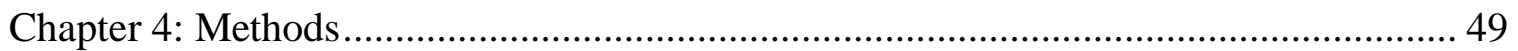

Documentary Research ................................................................................ 49

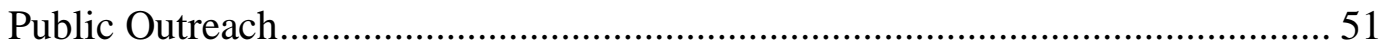

Ethnographic Research ……………………………................................. 55

Archaeological Field Methods ......................................................................... 61

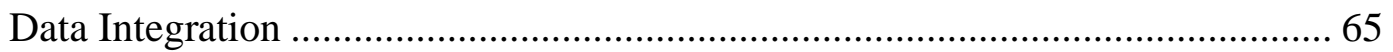

Chapter 5: Public Outreach and Ethnography Results and Discussion ............................. 66

Public Outreach Results and Discussion............................................................. 66

Survey Results and Discussion ...................................................................... 70

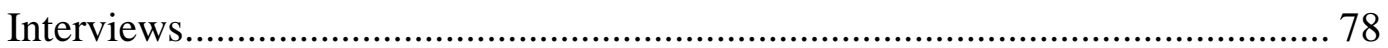

Informational Interview Results and Discussion ................................................ 79

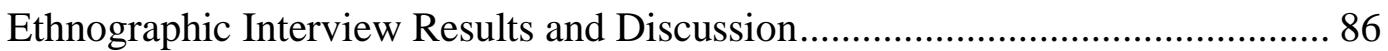

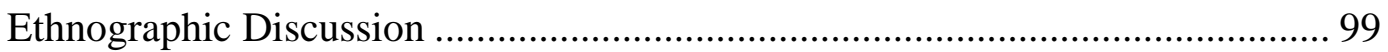

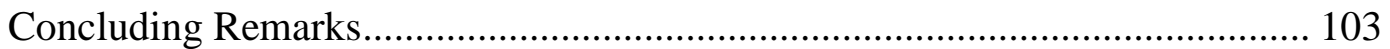

Chapter 6: Archaeological Results and Discussion ..................................................... 105

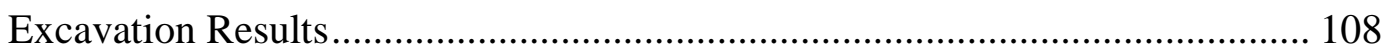

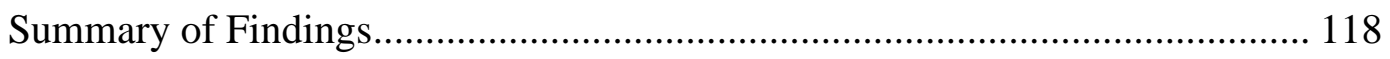

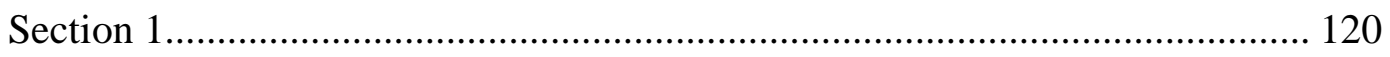

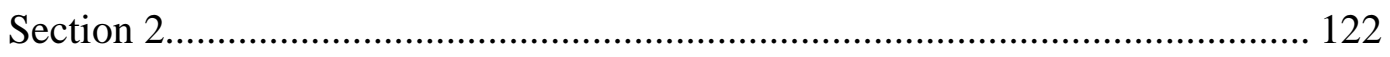

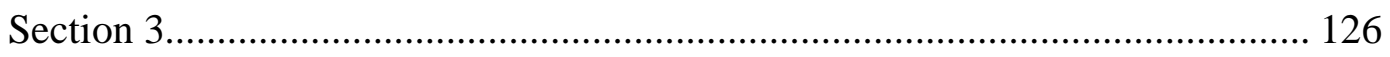




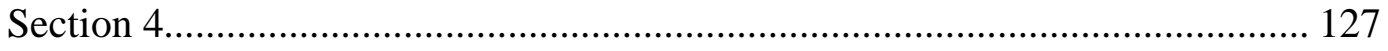

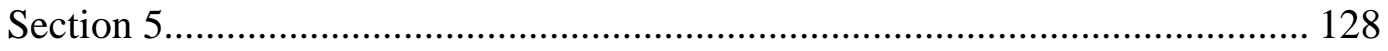

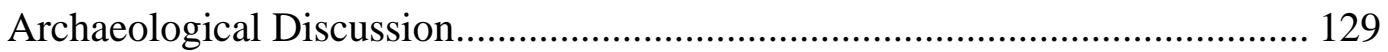

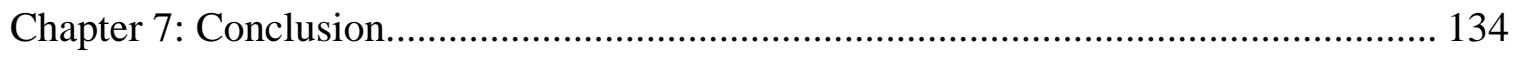

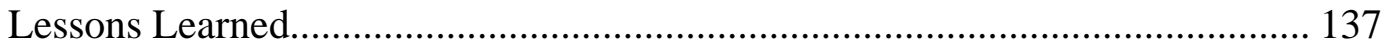

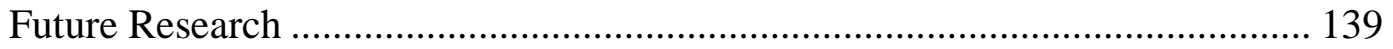

Concluding Remarks........................................................................... 140

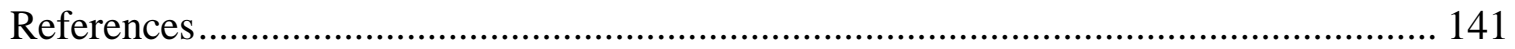

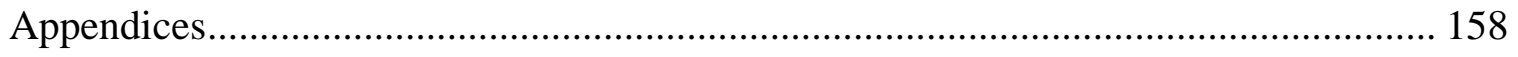

Appendix A: Additional Historical Background ..................................................... 159

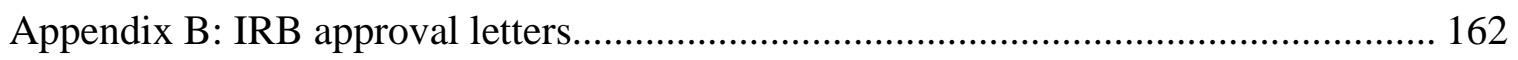

Appendix C: Recruitment letter to Edgewood Park homeowners ................................... 165

Appendix D: Recruitment letter to Edgewood Park renters ........................................... 167

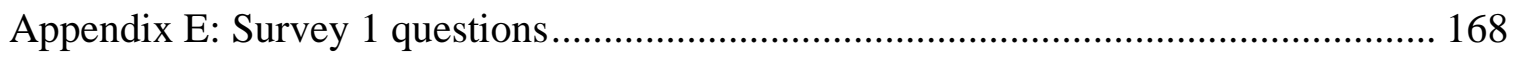

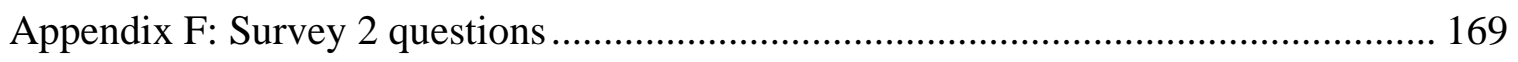

Appendix G: Survey informed consent................................................................. 170

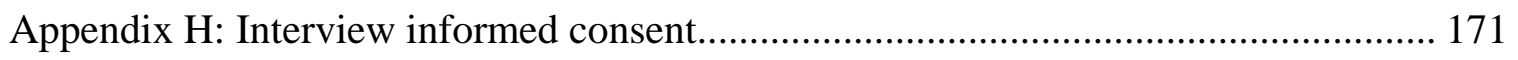

Appendix I: Informational interview questions .......................................................... 173

Appendix J: Ethnographic interview questions ..................................................... 174

Appendix K: Follow-up interview questions............................................................. 176

Appendix L: Excavation informed consent ………………..................................... 177

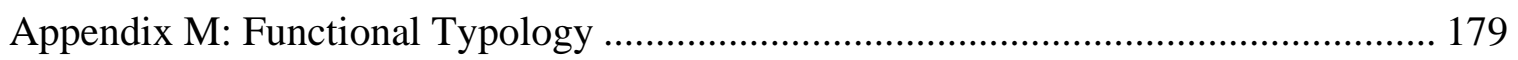

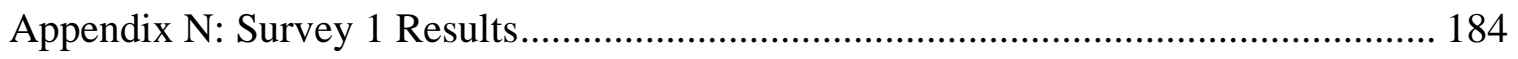

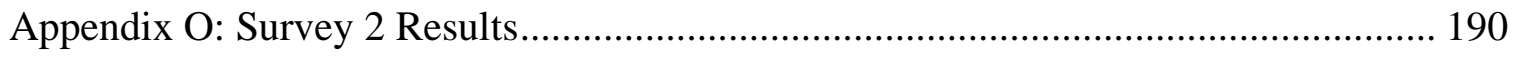




\section{List of Tables}

Table 2.1 Archaeological survey and testing projects within approximately one square

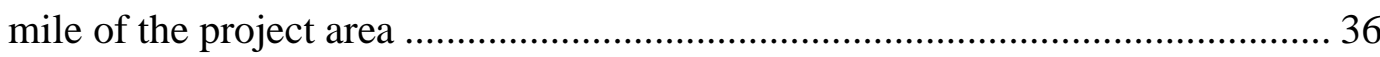

Table 2.2 Recorded archaeological sites within approximately one square mile of the

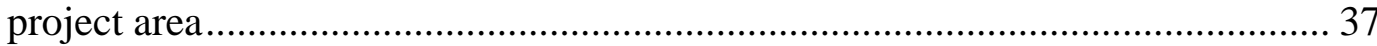

Table 5.1 Survey response categories: What comes to mind when you think of heritage?73

Table 5.2 Survey responses: Is heritage important in your community? ........................ 74

Table 5.3 Survey response categories: In what ways is heritage important in your community?

Table 5.4 Survey response categories: What comes to mind when you think of

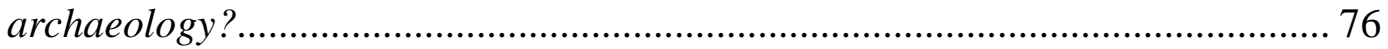

Table 5.5 Survey responses: Is archaeology important to you personally? ..................... 76

Table 5.6 Survey response categories: In what ways is archaeology important to your life

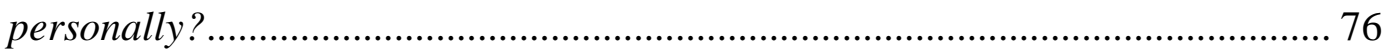

Table 5.7 Survey responses: Is archaeology important to society?................................. 76

Table 5.8 Survey response categories: In what ways is archaeology important to society?

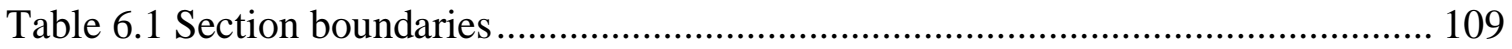

Table 6.2 Shovel test probes per property per section ............................................. 110

Table 6.3 Total volume of matrix excavated per property and per section $\left(\mathrm{m}^{3}\right) \ldots \ldots \ldots . .110$

Table 6.4 Count of 20th-century to present-day artifacts and artifact densities and percentages per section

Table 6.5 19th-century artifact counts and artifact densities and percentages per section.

Table 6.6 Precontact artifact counts and artifact densities and percentages per section. 112 Table 6.7 Undatable artifact counts and artifact densities and percentages per section . 113 Table 6.8 Representative artifacts by time period, and interpretation by STP 114 


\section{List of Figures}

Figure 1.1 Map of project area location in Vancouver, Washington ............................... 2

Figure 1.2 Fort Vancouver National Historic Site ....................................................... 2

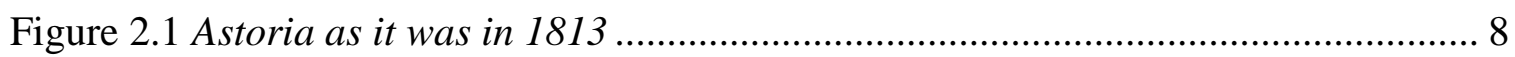

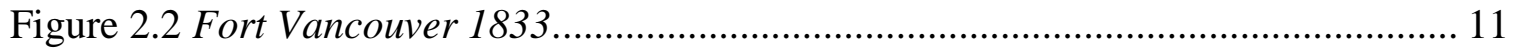

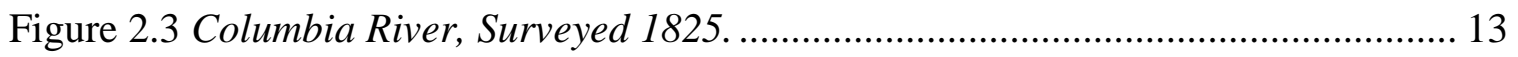

Figure 2.4 Sketch of Fort Vancouver and Adjacent Plains............................................ 14

Figure 2.5 Fort Vancouver and U.S. Military Post and Town Environs, 1859............... 14

Figure 2.6 Sketch of Fort Vancouver and Plain, Representing the Line of Fire in

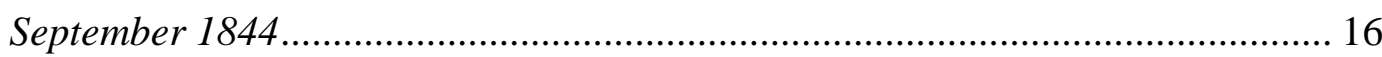

Figure 2.7 Map of the Government Reserve at Vancouver Oregon, Aug 1850, Surveyed

and Drawn by James Stewart, $2^{\text {nd }}$ Lt. RMR. Bvt. Cap't, U.S.A. ......................... 17

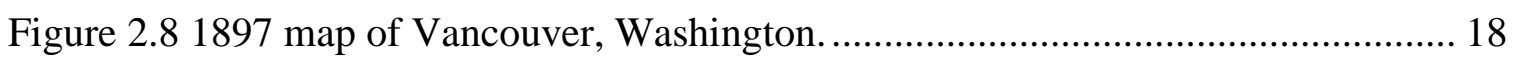

Figure 2.9 Landmarks relevant to the search for the first Fort Vancouver..................... 20

Figure 2.10 "The First Fort Vancouver" historical marker at Century Point, 1953 ........ 31

Figure 2.11 "The First Fort Vancouver" historical marker located on the campus of the

Washington State School for the Deaf............................................................. 32

Figure 4.1 Screenshot of the blog "Searching for the First Fort Vancouver" .................. 53

Figure 5.1 Percentages of survey respondents by age .......................................... 72

Figure 5.2 Percentages of survey respondents living in Vancouver and the project area 72

Figure 5.3 Percentages of survey respondents with previous knowledge of the first and

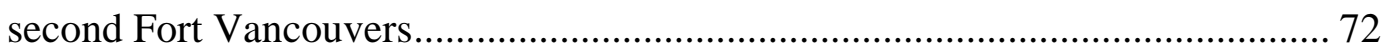

Figure 5.4 Hudson's Bay Company rum bottle .................................................... 83

Figure 6.1 Project area neighborhoods, Hudson's Bay and Edgewood Park. ............... 107

Figure 6.2 Map delineating the five project area sections ....................................... 109

Figure 6.3 Total number of artifacts per time period per section ................................ 113

Figure 6.4 Section 1 selected artifacts from EP 3: Burn barrel fragments .................... 121

Figure 6.5 Section 1 selected artifacts from STP 12: Metal objects ........................... 121

Figure 6.6 Section 1 selected artifacts from STP 12: Ceramics ................................. 121

Figure 6.7 Section 1 selected artifacts from STP 12: Blown-into-mold vessel glass ..... 122 
Figure 6.8 Section 2 selected artifacts: Domestic debris

Figure 6.9 Section 2 selected artifacts from EP 11: Lower Columbia Projectile Point Type

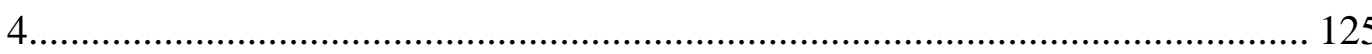

Figure 6.10 Section 2 selected artifacts from EP 11: American machine-cut nail ........ 125

Figure 6.11 Section 2 selected artifacts from EP 11: Board.................................... 126

Figure 6.12 Section 3 selected artifacts: Domestic debris ...................................... 127

Figure 6.13 Section 4 amethyst glass fragments..................................................... 128

Figure 6.14 Section 5 selected artifacts: Domestic debris ........................................ 129 


\section{Chapter 1: Introduction}

Current archaeological literature stresses the need for archaeology to become increasingly relevant in the modern world to benefit the discipline and to make positive contributions to society (Little 2002a; Derry and Malloy 2003; Little and Shackel 2007; Stottman, 2010; Rockman and Flatman 2012). Inspired by the call to advance archaeology's relevance, I used archaeological, documentary, and ethnographic research to engage a community in an archaeological project which directly impacts that community. Using public archaeology theory and methods, I situated archaeology in the present (Stottman 2010:4) by conducting archaeological excavation with residents on private property, and, through an ethnographic study, examined whether or not involvement in archaeological research affects how participants feel about heritage, archaeology, and place attachment.

Collaboration with residents in an area of Vancouver, Washington (Figure 1.1) revolved around the search for material evidence of a little known but important piece of the history of the fur trade post Fort Vancouver: the first (1825-1829) Fort Vancouver. This earlier fort, built by the Hudson's Bay Company, a British fur-trade company, was located on the upper plain above the Columbia River, about one-mile northeast of the second (1829) Fort Vancouver, commemorated as Fort Vancouver National Historic Site (Figure 1.2). The project involved four parts: documentary research, public outreach, ethnographic research, and archaeological investigation. 


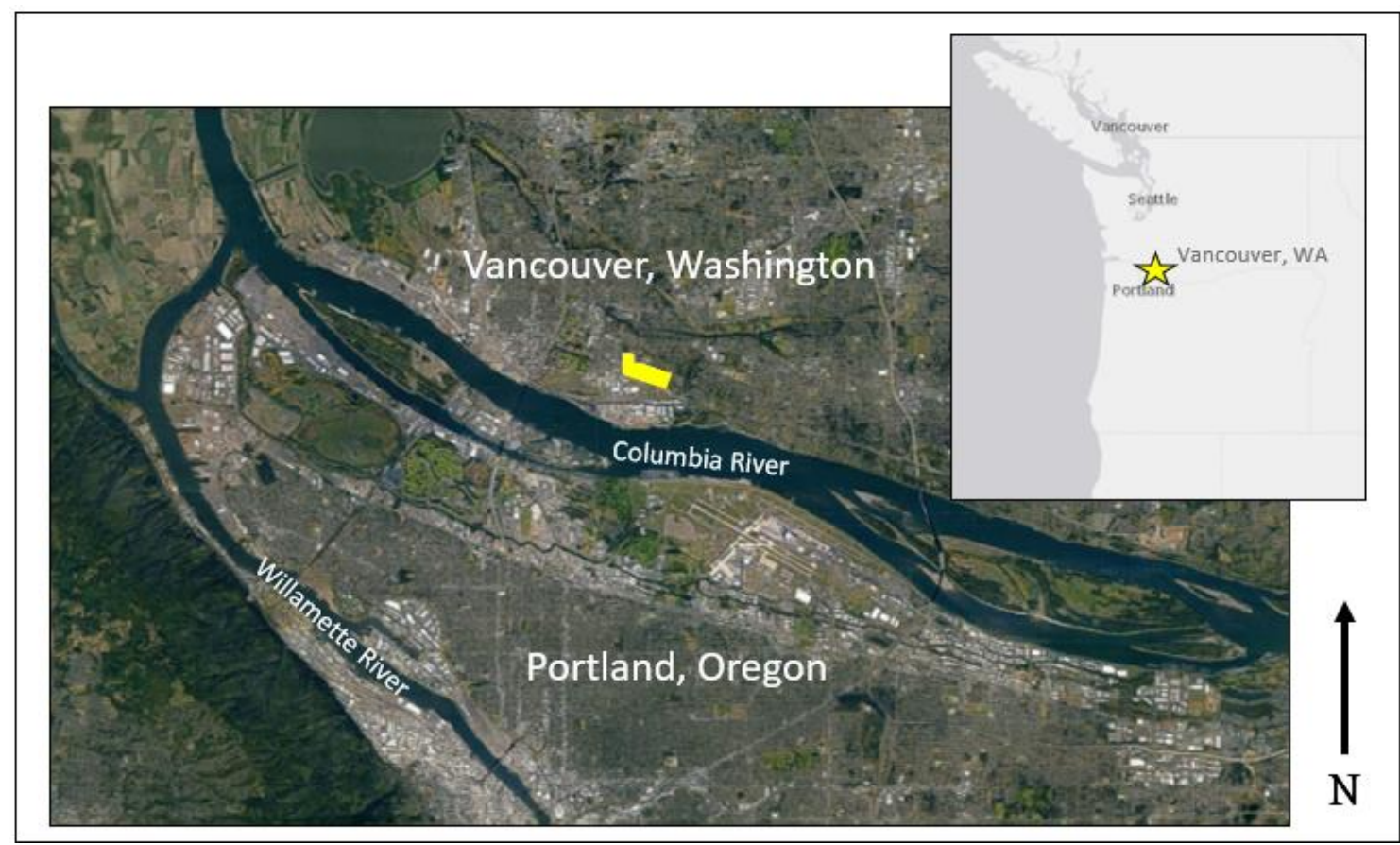

Figure 1.1 Map of project area location in Vancouver, Washington just north of the Columbia River. The polygon denotes the project area. Basemap from ArcMap 10.7.1 with labels added by the author.

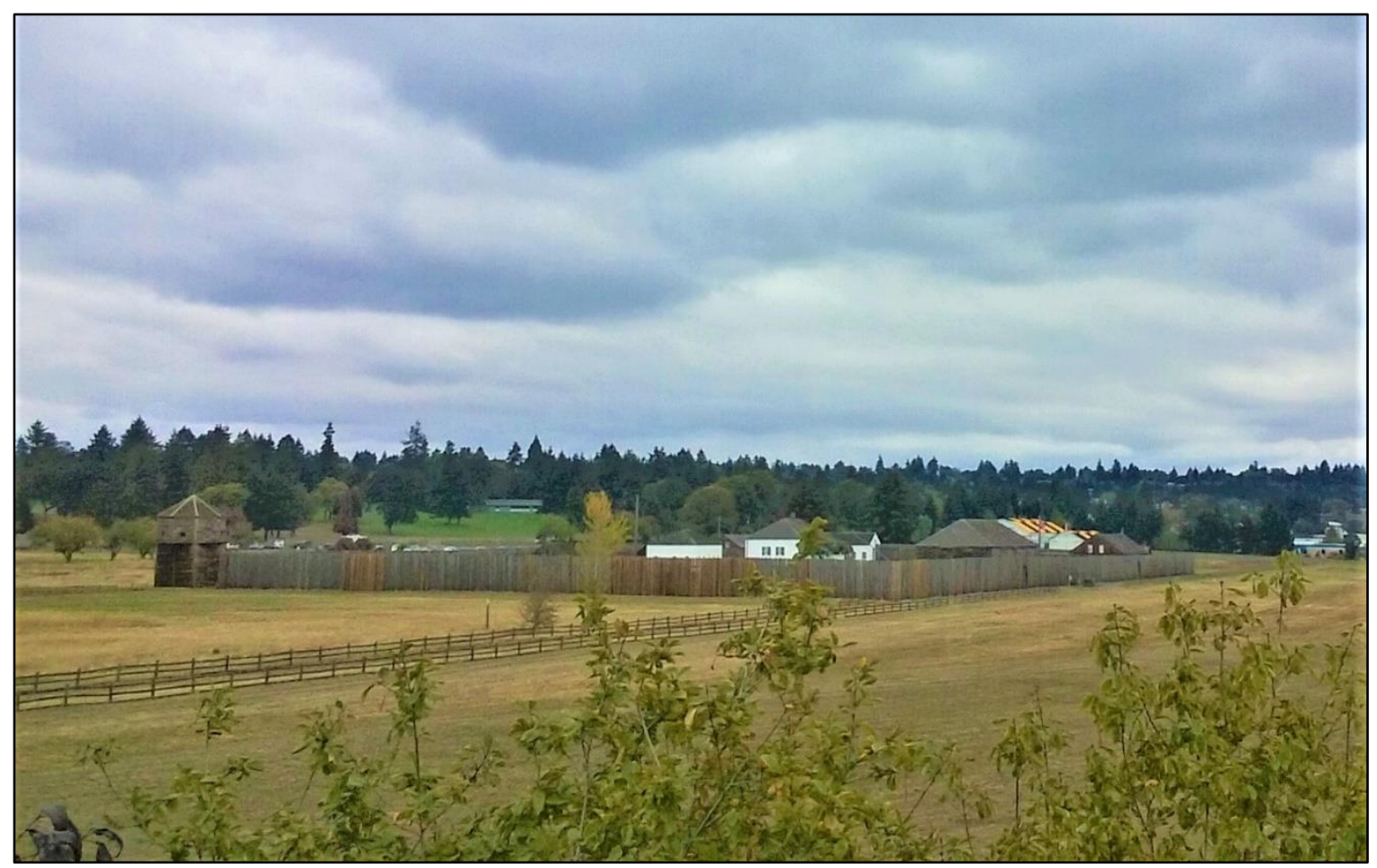

Figure 1.2 Fort Vancouver National Historic Site, a reconstructed commemoration of the second (1829) Fort Vancouver. View looking east northeast. 


\section{Public outreach}

As a public archaeology endeavor, outreach comprised a crucial part of this project, and included social media, public presentations, and newspaper articles. These methods were critical for recruiting participants, generating support for the project, and returning the results of the research back to the community.

\section{Ethnographic study}

I used ethnographic methods to gather data on whether or not involvement in this project affected how people feel about heritage, archaeology, and place attachment. As archaeologists become increasingly accountable to the communities their research affects, ethnography becomes more important for understanding the effects of archaeology on community attitudes about place, heritage (Hollowell and Mortensen 2009:5), and archaeology. Surveys administered at two public presentations at the beginning and at the end of the project assessed attitudes in the wider public, and interviews with excavation participants before and after excavation measured changes in the attitudes of individuals directly involved in archaeological research.

\section{Archaeological investigation}

I conducted a subsurface archaeological survey to search for the location of the first Fort Vancouver and any associated artifacts, adding information to the history of Fort Vancouver while building a deeper historical context for current residents by bringing to light past communities. Former communities influenced and are reflected in the current neighborhoods, and my project helped strengthen community bonds by using archaeology to reveal the interconnectedness of people over long expanses of time based 
on place. For communities on or near archaeological sites, "the relationships between the present and the past is immediate and intense" (Pyburn 2003:179), and this archaeological project served as a vehicle for creating connections between individuals, area history, and the discipline of archaeology (e.g. Derry and Malloy 2003).

Project significance

As arguably the most important European settlement in the Pacific Northwest (Hussey 1957:vii), Fort Vancouver holds great significance in the history of the United States. The location of Fort Vancouver enormously impacted settlement and development of the local area as well as the wider region, and directly influenced the look of the landscape today. While much is known about the second (1829) Fort Vancouver, little information remains of the first (1825) Fort Vancouver. The general location of the first fort on the upper plain was discerned decades ago, but the evidence of its exact location has remained elusive. Finding material remains of the first fort would add information to the history of Fort Vancouver, the City of Vancouver, the North American fur trade, and the Pacific Northwest.

Additionally, because archaeology can provide benefits for diverse stakeholders (Little 2002b:3), this thesis adds to the increasing body of research seeking data on how communities and individuals are affected by archaeological research. Understanding the effects of archaeological research on stakeholders helps archaeologists find ways to make this research more relevant to the public.

I anticipated that the unearthing of material culture through archaeological research would aid in "stimulating thought and awareness" (Cressey et al. 2003:15) of 
area history and of the people who occupied the landscape over thousands of years. Which pasts are presented via heritage and archaeological research can unfortunately result in dichotomies of inclusion and exclusion, for those who feel connected to the past and those who do not. One remedy, which I explore in this thesis, is to establish connections across time based on place which can include everyone by making “archaeology an integral part of a community’s heritage” (Shackel 2004:14).

As Little (2007b:75) writes, "One of the most important things we can do as a discipline is to make our results accessible and useful." Although opportunities for projects like this one are relatively rare, my methods serve as a model for other archaeologists and researchers interested in working with community members, to bolster scientific research and to make this research accessible and relevant to all stakeholders.

\section{Thesis organization}

I divided this thesis into seven chapters. Chapter 2 presents background information on the project, including a history of Fort Vancouver, a description of the project area, and a summary of previous archaeological investigations relevant to this project. Chapter 3 provides a review of the theoretical underpinnings of the project.

Chapter 4 outlines the public outreach, ethnographic, and archaeological methods used in this project. Chapter 5 presents the results and discussion of the ethnographic research. Chapter 6 details the results and discussion of the archaeological investigation. Chapter 7 provides concluding remarks. 


\section{Chapter 2: Background}

In this chapter, I provide an overview of the history of Fort Vancouver, followed by a brief description of the project area. I end with a summary of previous archaeological explorations relevant to the first (1825) Fort Vancouver and the project area. I have included additional background information on the North American fur trade and the Hudson's Bay Company in Appendix A.

\section{Historical Background}

Fort Vancouver stood as "the emporium of the western fur trade" (Hussy 1957: vii) and is considered "the most important settlement in the Pacific Northwest" (Hussey 1957:1). Founded in 1825 by the Hudson's Bay Company (HBC), a British fur trade company, Fort Vancouver served as the HBC's Columbia Department headquarters and the center of international trade in the west (Hussey 1957:1). Situated on the Columbia River's north bank about one hundred miles from the river's mouth and near the confluence of the Columbia and Willamette Rivers, Fort Vancouver was ideally located amid the river and tributary arteries of the Pacific Northwest fur trade (Sage 1948:94). The fort received supplies from ocean-going vessels, distributed these items to interior HBC posts, and assembled all furs collected in the west for packaging and shipment to international ports (Hussey 1957:1). The fort hosted the region's first largescale agricultural pursuits and industrial plants; lumber, pickled salmon, seeds, dairy products, and crops produced at Fort Vancouver supplied the region's fur trade posts as well as foreign ports for decades (Hussey 1957:1-2), making Fort Vancouver an 
international hub as well as a popular destination for American settlers in the west (Hussey 1957:2).

\section{Before Fort Vancouver}

As the North American fur trade expanded after 1800, numerous posts were constructed across the continent including many in the Pacific Northwest (Caywood 1967:46). Important in the story of Fort Vancouver was Fort Astoria (Figure 2.1), established in 1811 by the Pacific Fur Company founded by the American John Jacob Astor (Ronda 1990). Fort Astoria was the first permanent Anglo-European settlement west of the Rocky Mountains (National Park Service 2016), and was situated on the southern bank of the Columbia River at its mouth in what is now Astoria, Oregon. Astoria was one in a series of forts built by Astor in an effort to infiltrate the Pacific maritime fur trade, and it soon became the center of regional trade on the lower Columbia River (Nassaney 2015:60).

In 1812, shortly after Fort Astoria's founding, the United States, disturbed that Great Britain continued to undermine American sovereignty and meddle in American affairs, declared war on Great Britain and attempted to conquer Canada, a British colony (Abel 2012:9). Victory for the United States in the War of 1812 would mean moving its northern border far above the 49th parallel. The war, full of blunders and mismanagement on both sides, ended with the Treaty of Ghent in 1815 (Abel 2012:10) which called for status quo ante bellum (Lavender 1958:108). This meant all borders and land ownership should be as they were before the war. This was a problem at Fort Astoria which had changed hands during the War of 1812. In October 1813, the North West Company, a 
British fur trade operation, bought Fort Astoria from the Americans (Lavender 1958: 105), renaming it Fort George (National Park Service 2016). After the war, the British argued they should be permitted to keep Fort George which they had bought not seized during the war; however, America reclaimed ownership of the fort (Lavender 1958:108) while permitting the British to continue operating it. This sort of dual possession of the fort was possible under the Convention of 1818, which allowed for British and U.S. joint occupation of the land west of the Rocky Mountains to the Pacific Ocean for a period of ten years (Sage 1948:84). After that time, the boundary between the United States and Canada west of the Rockies was meant to be resolved. In 1821, after a series of crises, Britain forced the North West Company to merge with the HBC (Ronda 1990:315), whose governors elected to use Fort George as the Company's principal base of operations in the west.

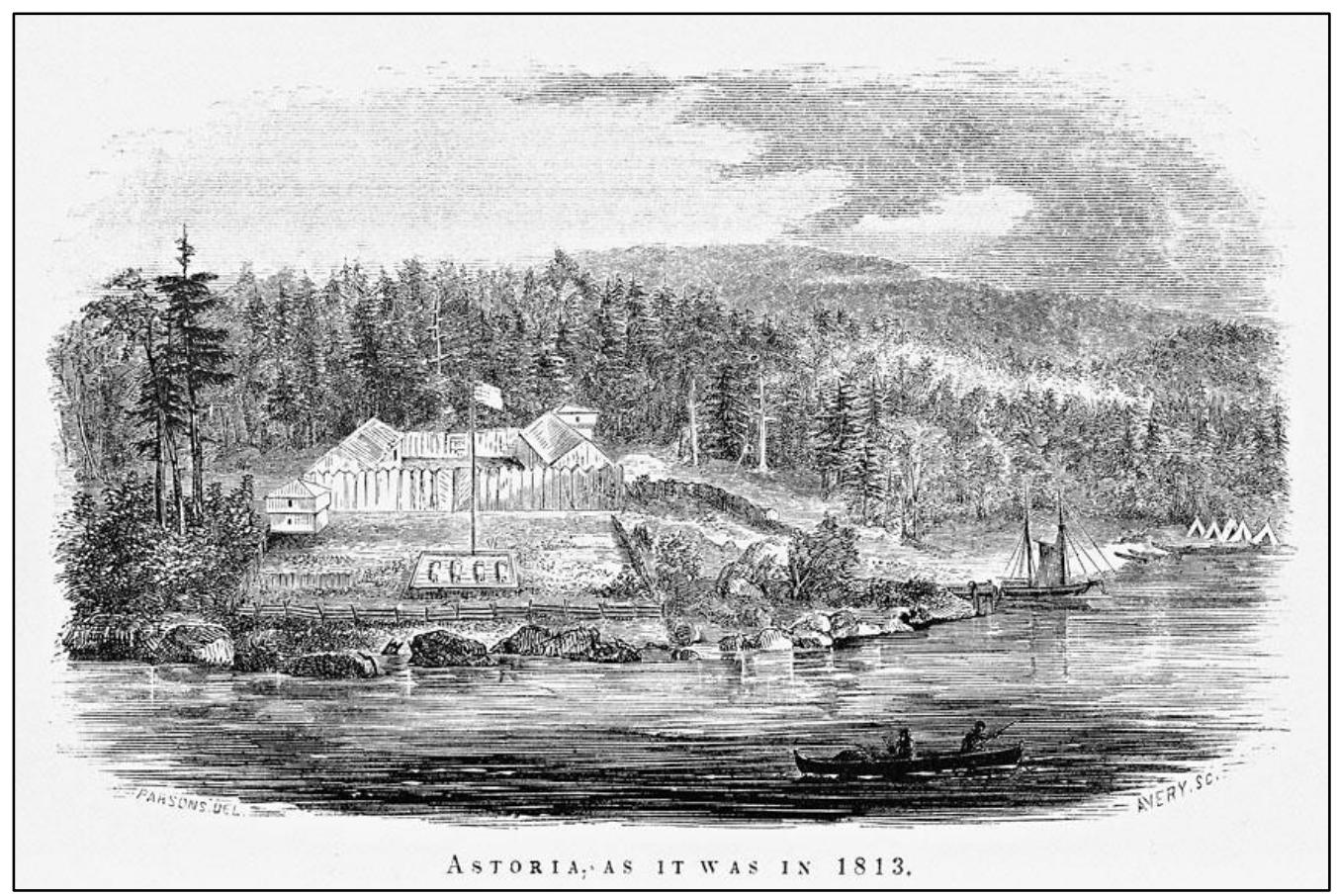

Figure 2.1 Astoria as it was in 1813 by Gabriel Franchére. Courtesy Oregon Historical Society. 


\section{The First (1825) Fort Vancouver}

Fort George, however, did not live up to standards as the regional headquarters of a vast and powerful company. In 1824, the HBC directed the governor of its territories in North America, George Simpson, to analyze operations at Fort George (Hussey 1957:37). Simpson found the fort unprofitable because, for one thing, too much competition depleted one of the most important fur sources in the Pacific Northwest, the coastal beaver population, to the point of extreme scarcity (Merk 1968:xix). But perhaps an even larger problem for the $\mathrm{HBC}$ was the state of the Columbia Department, which Simpson deemed "neglected, shamefully mismanaged and a scene of the most wasteful extravagance and the most unfortunate dissension" adding, "It is high time the system should be changed and I think there is ample Field for reform and amendment" (Merk 1968:43). During his visit to Fort George, Simpson removed what he saw as unfit, including the fort's managers, and installed Dr. John McLoughlin as Chief Factor to carry out the mandated reforms (Merk 1968:xx). However, in spite of the rejuvenation brought about by McLoughlin, Fort George continued to struggle (Merk 1968:xxi).

Fort George's problems, plus upcoming boundary negotiations, led the HBC to see the wisdom of relocating its western headquarters. Britain and the United States differed on where the border between the United States and Canada should be when the Convention of 1818's period of joint occupation came to an end; the United States wanted the border to continue along the 49th parallel to the Pacific Ocean, while Britain proposed it should extend along the 49th parallel from the Rockies to the Columbia River, and then follow the Columbia to the Pacific (Merk 1968:xxi). Britain realized it 
could exploit the presence of $\mathrm{HBC}$ posts in the region to direct resolutions in its favor during boundary negotiations, and that a move to the north side of the Columbia River could strengthen British territorial claims (Merk 1968:xxi). The HBC ordered Simpson to find a suitable spot for a new post, and Simpson recommended moving the fort near the confluence of the Columbia and Willamette Rivers (Erigero 1992:13; Taylor 1992:41). Simpson sent HBC Chief Factors John McLoughlin and Alexander Kennedy to scout the location for the new fort (Hussey 1957:38).

Besides abandoning Fort George because of its unprofitability and in anticipation of boundary resolutions, Simpson and McLoughlin both later wrote that a key reason for the move was to find land suitable for agricultural pursuits (Hussey 1957:38). When McLoughlin and Kennedy laid eyes on the fertile soil of the three-mile long and one-mile wide Jolie Prairie (Figure 2.2), also called Belle Vue Point, they knew the search for the new fort's location was over (Hussey 1957:39). Situated along the Columbia River 100 miles upriver from Fort George (Wilson and Langford 2011:8), about six miles from its confluence with the Willamette River, and where present-day Vancouver, Washington sits, Governor Simpson seemed quite pleased with the location and the knowledge that the climate and the soil of the Jolie Prairie would support both crops and livestock superbly (Hussey 1957:41). For the fort itself, the upper prairie was chosen, a defendable bluff above the Columbia floodplain, about 1 to $1 \frac{1 / 4}{4}$ miles (1.6 to 2 kilometers) north and above the floodplain of the river (Erigero 1992:18-19; Hussey 1957:40), overlooking the Jolie Prairie. 


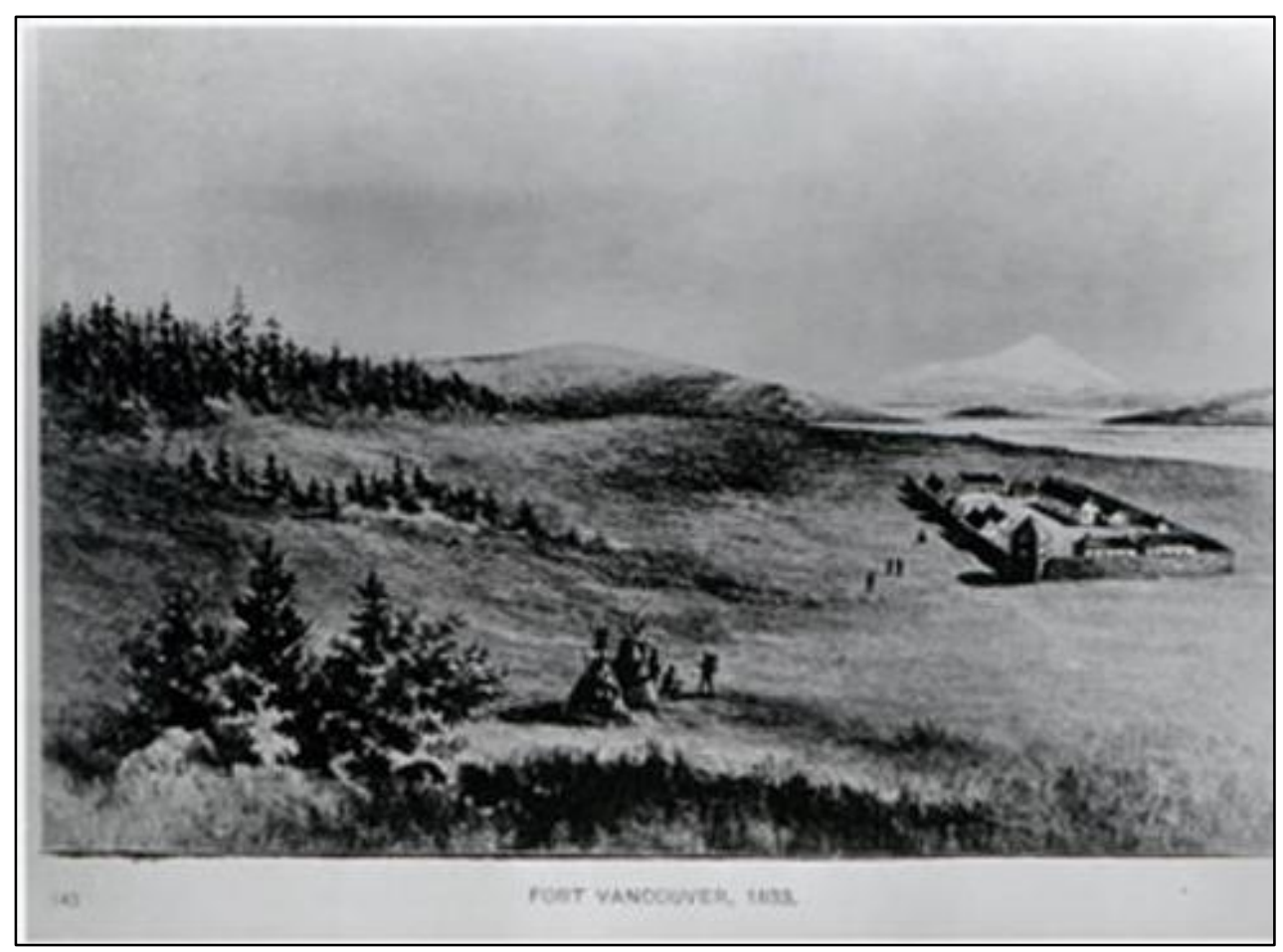

Figure 2.2 Fort Vancouver 1833. Image of the second Fort Vancouver, showing the Jolie Prairie, view looking east. Courtesy National Park Service.

Importantly for trade, the chosen location not only possessed a commanding view of the river and surrounding landscape, but it was visible from the river (Hussey 1957:25) and was positioned in an area amply populated and used for millennia by a plethora of Native groups (Deur 2012:9). American Indian groups gathered at the Jolie Prairie seasonally for fishing and for harvesting plants like camas (Deur 2012:16). Diarists of the day note the abundance on the upper and lower prairies of camas (Camassia quamash and C. leichtlinii) (Erigero 1992:19; Deur 2012:10), a starchy root that was eaten baked or ground into flour and was a dietary staple in the region. It is likely that Native groups maintained both prairies through controlled burning to promote growing conditions for the camas plants (Deur 2012:10). 


\section{The location on the upper terrace}

At the outset of this study, the first Fort Vancouver was presumed to be located near the edge of the bluff where the Washington State School for the Deaf (WSSD) currently sits. However, my documentary review pertaining to the fort's location reveals that, while no known documents pinpoint the fort's exact location, evidence suggests that the fort was indeed located on the high ground above the Columbia River, but possibly farther back from the edge of the bluff, and somewhat east of the WSSD. Landmarks named in the following discussion are labeled on Figure 2.9.

That the first fort was located on the upper terrace is undisputed, and contemporaneous maps indicate that it was situated on the upper plain above the Columbia where the Edgewood Park neighborhood is now. Three known sketch maps show the general location of the fort on the upper terrace: Columbia River, Surveyed 1825 (Figure 2.3); Vavasour's 1845 Sketch of Fort Vancouver and Adjacent Plains (Figure 2.4); and Covington's 1859 Fort Vancouver and U.S. Military Post and Town Environs (Figure 2.5), which does not have the first fort labeled, but does indicate the potato field on the upper plain where the fort was said to have been built. In addition to these maps, diarists locate the fort on the upper terrace, such as Governor Simpson who describes the site of the fort in his 1825 journal: "The Establishment is beautifully situated on the top of a bank about $1 \frac{1 / 4}{4}$ Miles from the Water side commanding an extensive view of the River the surrounding Country and the fine plain below" (Merk 1968:124). This statement corroborates landmarks in sketches of the fort's location, and Simpson's mention of the extensive view indicates that the land around the fort was clear 
of trees. The open prairie landscape is reflected as well in the writings of Scottish physician and naturalist John Scouler during his 10-day stay at Fort Vancouver in May 1825 (Scouler 1905:173-175). Scouler notes that the land surrounding the fort contained "about 300 acres of excellent land, on which potatoes and other vegetables are cultivated" (Scouler 1905:174). Scouler also notes the abundance of camas, which he calls Phalagium esculentum, saying, it "is much used by the natives as a substitute for bread. They grow abundantly in the moist prairies, the flower is usually blue, but sometimes white flowers are found" (Scouler 1905:174). From this passage it is clear that a camas prairie existed on the upper terrace, most likely fire-maintained by the American Indians of the region.

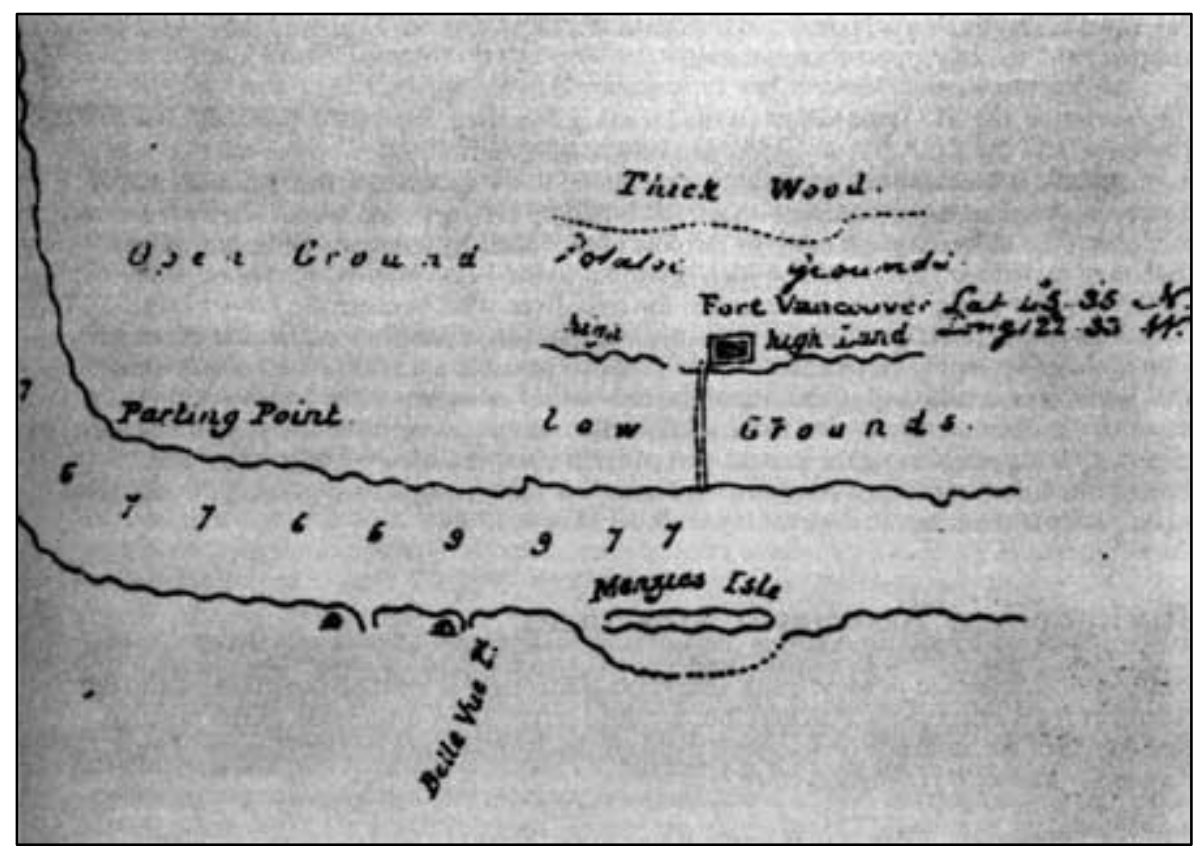

Figure 2.3 Columbia River, Surveyed 1825. Portion of the map showing the upper prairie of the first Fort Vancouver. Printed at Lithographic Establishment, Quarter Master Generals Office, Horse Guards, October 1826. Note: Geographic coordinates (upper right on map) refer to a point 5 miles southeast of the project area, in the Columbia River. Courtesy National Park Service. 


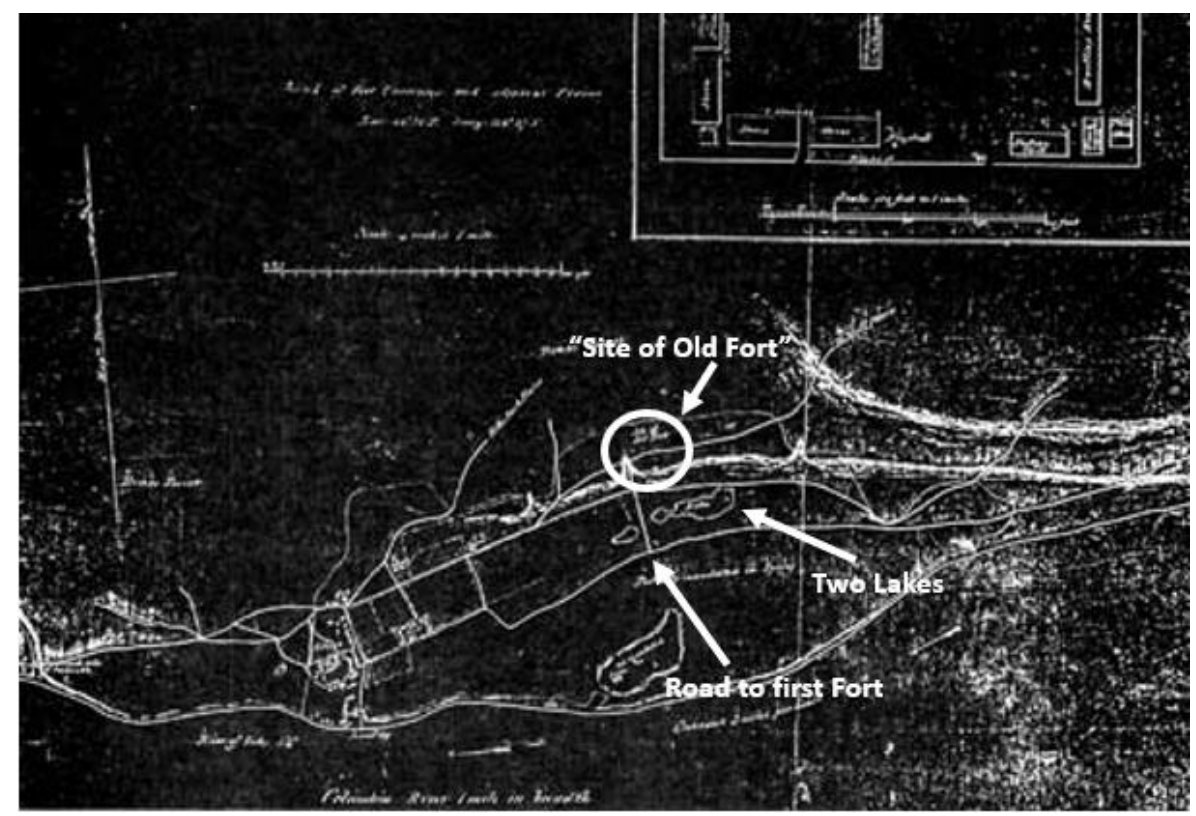

Figure 2.4 Sketch of Fort Vancouver and Adjacent Plains by Lt. Mervyn Vavasour, 1845. Labels and arrows added by the author emphasize map's "Site of Old Fort," the two lakes on the lower plain, and the road leading between the lakes up the bluff to the first fort. Courtesy National Park Service.

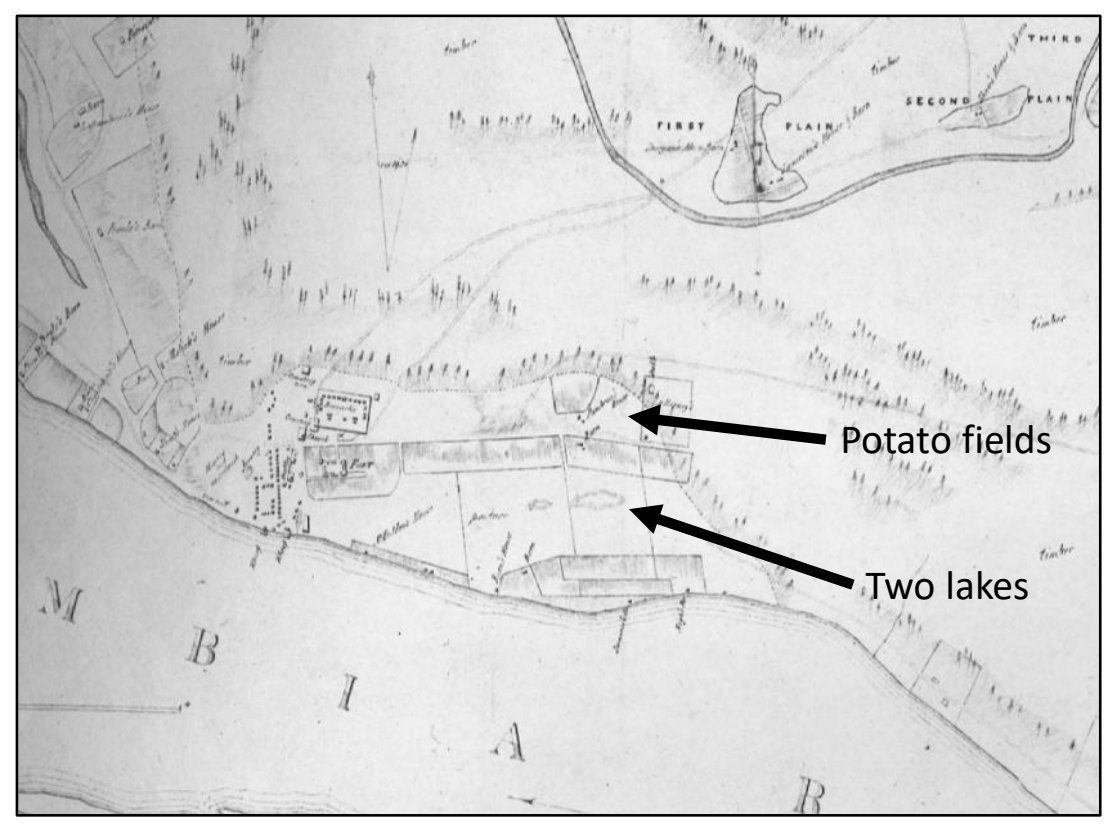

Figure 2.5 Fort Vancouver and U.S. Military Post and Town Environs, 1859. Portion of map. Labels and arrows added by the author emphasize potato fields near the location of the first Fort Vancouver and the two lakes on the plain below the first fort. Courtesy National Park Service. 
Simpson mentions that the plain below the fort "is watered by two very pretty small Lakes" (Merk 1968:124), and these lakes are depicted on maps of the day (Figures 2.4, 2.5, 2.6, and 2.7). Maps also show a road from the river to the fort which travels between the lakes (Figures 2.3, 2.4, and 2.5). The landscape has changed dramatically since 1825, so maps from farther back in time which label these lakes are most useful. An 1897 USGS map shows six lakes or ponds at the base of the terrace below the potential site of the first Fort Vancouver (Figure 2.8). By 1960, only the western most of these lakes existed. By 1990 none of the pond was left, except for a shallow, stagnant wetland at 5th and Grove streets (DeLyria 2000:2). Today the entire area is a filled wetland, with industrial buildings atop the fill. Though these lakes or ponds no longer exist, the landscape today remains marshy attracting water fowl such as Canada geese and ducks. 


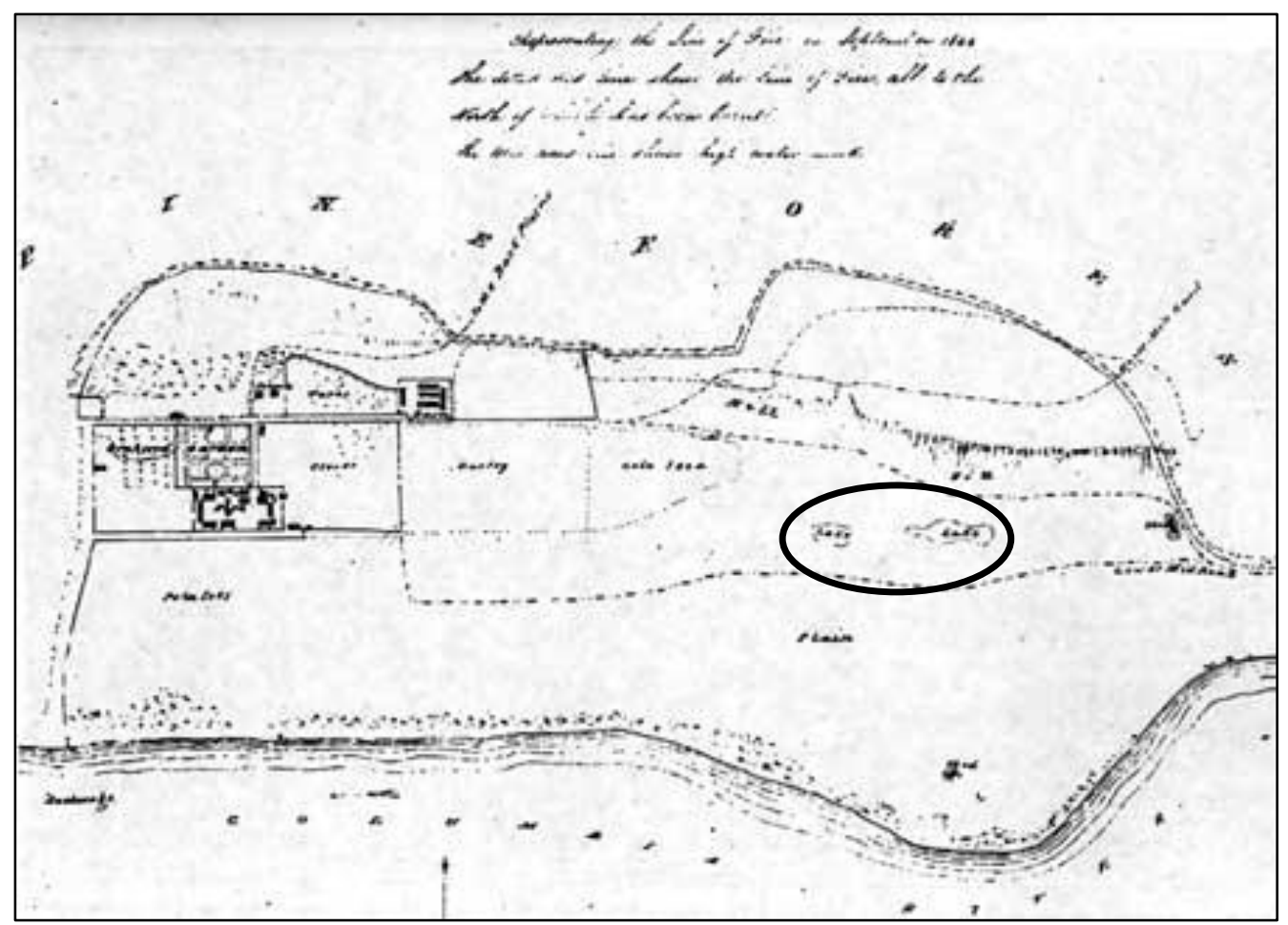

Figure 2.6 Sketch of Fort Vancouver and Plain, Representing the Line of Fire in September 1844 by Henry Peers. Black oval added by the author surrounds the two lakes below the bluff. Courtesy National Park Service. 


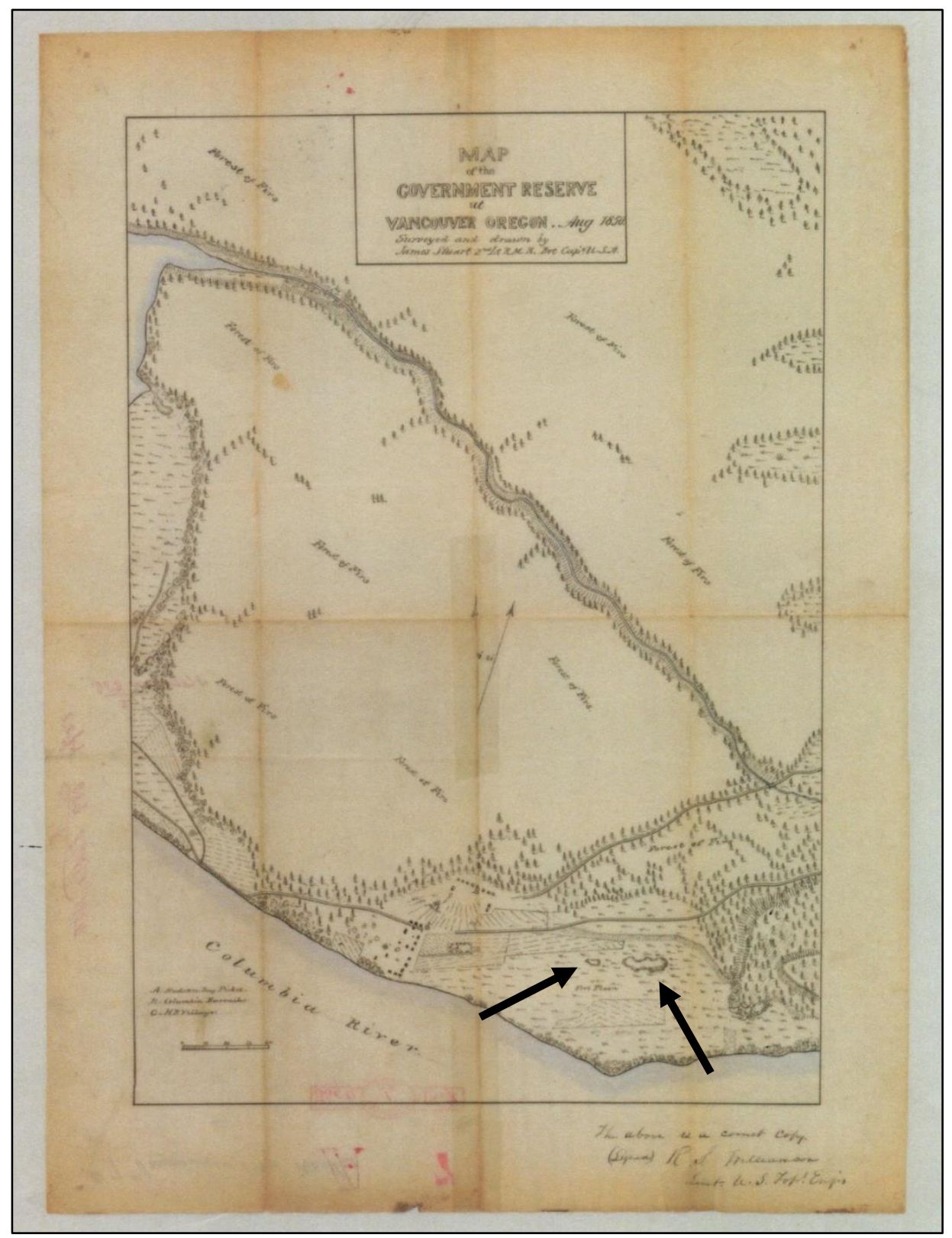

Figure 2.7 Map of the Government Reserve at Vancouver Oregon, Aug 1850, Surveyed and Drawn by James Stewart, $2^{\text {nd }}$ Lt. RMR. Bvt. Cap't, U.S.A. Black arrows added by the author point to the two lakes on the plain below the first fort. Courtesy National Park Service. 


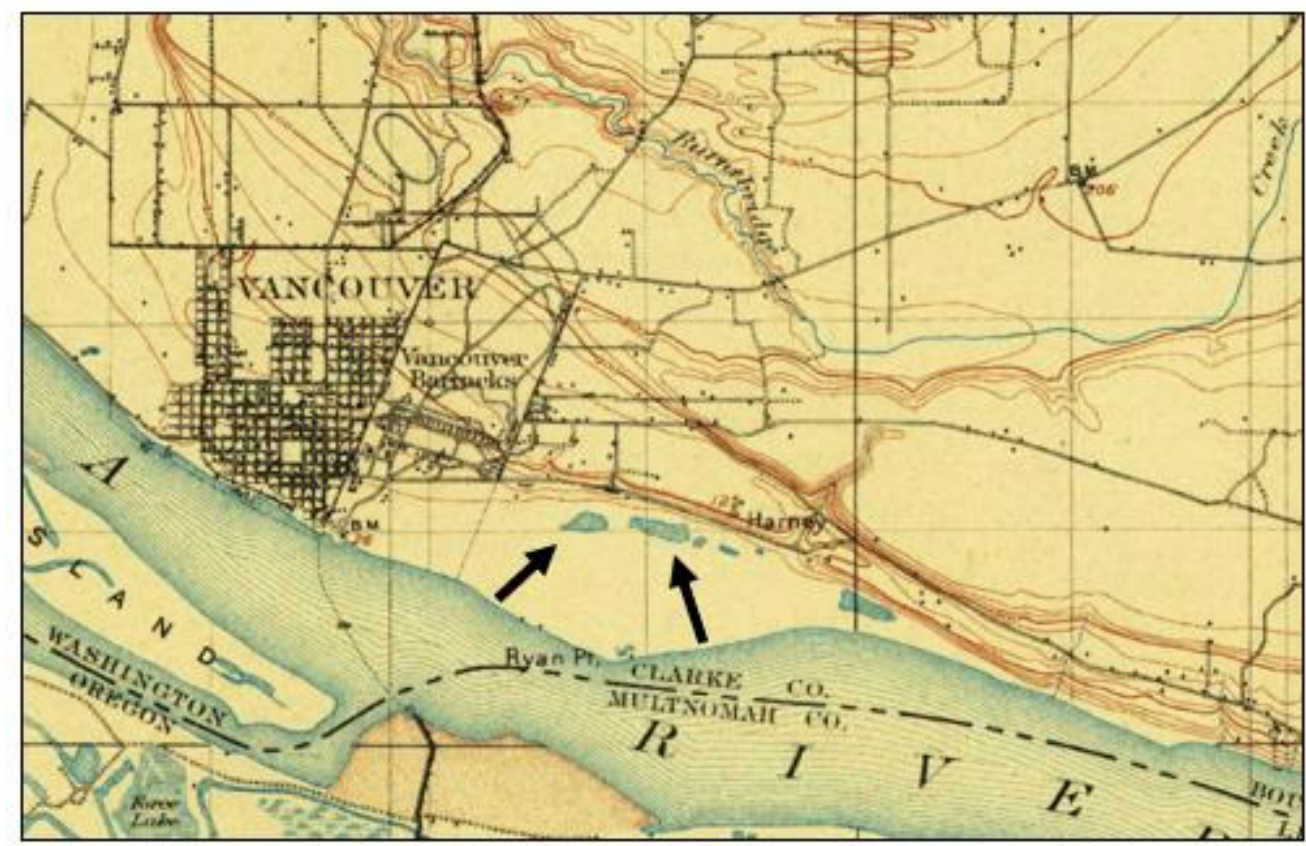

Figure 2.81897 map of Vancouver, Washington. Black arrows added by the author point to two lakes on the plain below the first fort. Courtesy U.S. Geological Survey Historical Topographic Map Collection.

My documentary research located eye-witness accounts which place the first fort farther back from the edge of the bluff than where the WSSD now stands. Captain Charles Wilkes of the U.S Exploring Expedition visited the site in 1841 and commented that the fort sat "just on the brow of the prairie" (Erigero 1992:19). Instead of meaning the edge of the bluff as many assume, a brow is a summit, peak, or crest, making the brow of the prairie possibly the rise of land that runs roughly in the middle of this upper prairie in an east-west orientation. This interpretation places the fort a slight distance back from the bluff edge in between present-day Clark and Lewis Avenues. This location for the fort is supported by John Scouler, who notes that the fort was "situated in the middle of a beautiful prairie" (Scouler 1905:174), and by Dr. William McKay who lived at the first fort as a child and remembered the fort being "near where General Harney 
built his fine residence" (Clarke 1905:182). Harney's homestead was located where Harney Elementary School now stands on the north side of Evergreen Blvd.

As well as being further back from the bluff than the WSSD, it is plausible that the fort was also farther east. In 1885, Alley and Munro-Fraser (1983:26) comment that the first fort was built "on a commanding elevation, now included in what is the property of Mrs. George Durgin.” Elizabeth Durgin's land claim appears on an 1860 Donation Land Claim Map (Clarke County 1888), stretching north/south from present-day Mill Plain Blvd to the Columbia River, and from somewhere between Grove and Ash Street on the west to around Date Street or Edwards Lane on the east. This puts the fort somewhat east of the presumed location at the WSSD into the heart of the Edgewood Park neighborhood. 


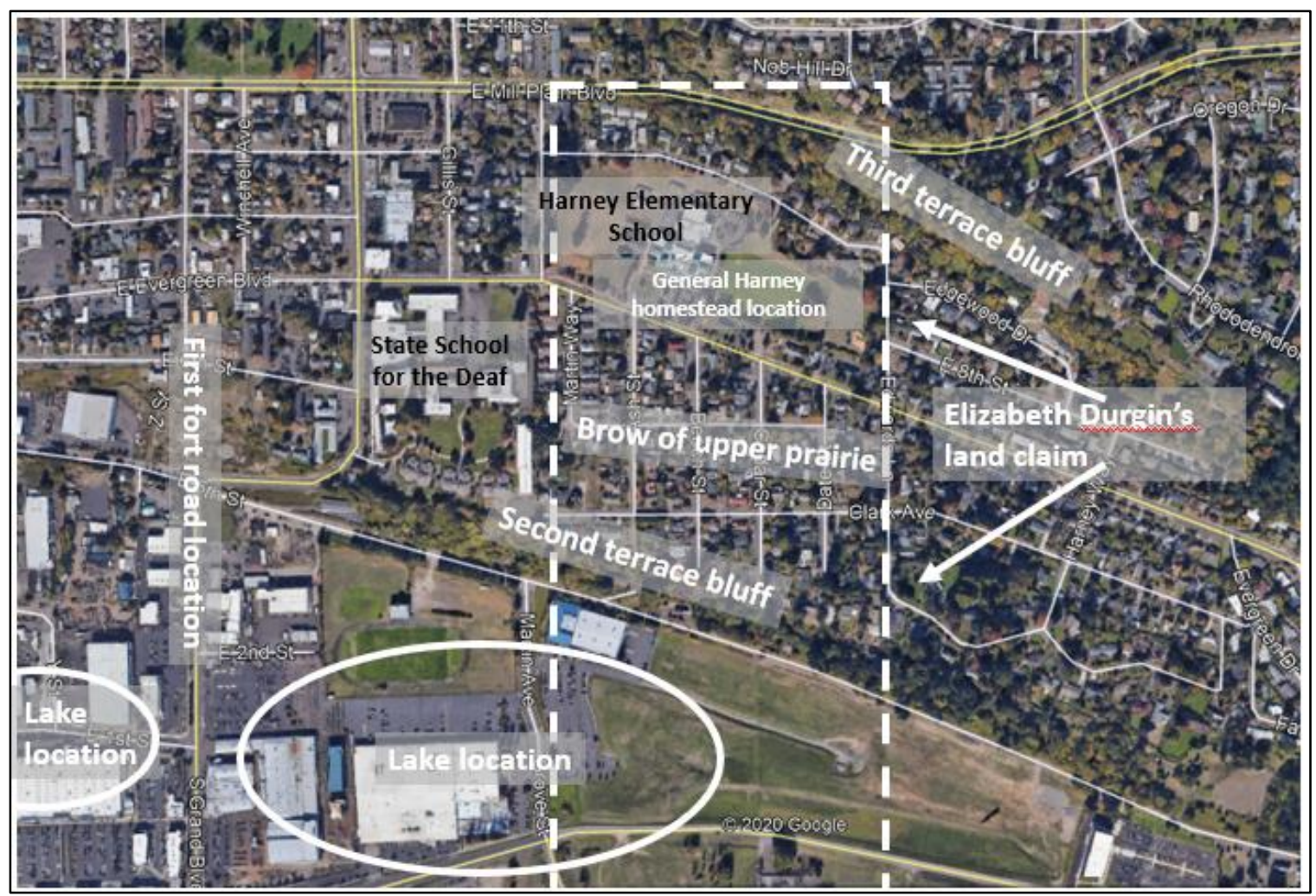

Figure 2.9 Landmarks relevant to the search for the first Fort Vancouver. Labels added by the author mark locations of project area landmarks mentioned in documentary record. Basemap from Google Earth Pro.

\section{Construction of the first Fort Vancouver}

Construction of the new fort began sometime between November 1824 and March 1825 (Erigero 1992:15), with the area of the fort filling a space between 3/4 of an acre and almost 1 1/2 acres (Erigero 1992:23; Hussey 1957:43). While much of the landscape was already clear of trees, Alley and Munroe-Fraser (1983:26) suggest that the HBC removed timber by ax, and these logs, prepared with a whip-saw, made up the material of which the fort was built. John Scouler notes that the new fort resembled Fort George, only smaller (Scouler 1905:174), and indeed supplies and stores were said to be moved from Fort George to Fort Vancouver by lighters and canoes (Hussey 1957:44). Flooring 
was also brought from Fort George (Alley and Monroe-Fraser 1983:26), although it is unclear whether these were made specifically for Fort Vancouver or were re-used from Fort George. Roofing comprised cedar bark collected by Native Americans hired by the HBC (Erigero 1992:23), and sub-standard bricks originally intended for Fort George likely formed the chimneys (Hussey 1957:49). An HBC report of unknown authorship from about 1825 describes the fort:

Fort Vancouver is built on the north side of the Columbia about three miles above the Mult-no-mah [Willamette River] on a high Bank one mile from the River. [B]etween the Bank and the River there is a low plain two miles in length. [I]n years of High water this plain is overflown which obliged us to Build at such a distance from the River. The Fort is two hundred fifty feet in depth by one hundred and fifty in breadth surrounded by a Stockade seventeen feet above ground and flanked by two temporary Bastions with three pieces of Artillery in Each.

The Buildings at present erected are two Stores of forty by thirty feet one dwelling House of sixty by forty feet an Indian House thirty by twelve and tradesmens work shop and a temporary powder magazine (Hudson's Bay Company 1825).

The "dwelling house" mentioned in the passage was for McLoughlin and his wife and two young children who lived with him at the fort (Morrison 2004:123). Also included inside the stockade were temporary quarters which were likely canvas tents (Erigero 1992:23) housing a diverse set of employees, including many Native Americans and Native Hawaiians (Deur 2012:57; Wilson 2014:23). Artillery located in the bastions were either twelve-pounder (Hussey 1957:51) or eighteen-pounder (Lavender 1981:55) cannons transferred upriver from Fort George. In addition, outside of the stockade walls, the blacksmith William Cannon from Astoria is said to have set up a forge "under a 
majestic fir tree during the construction of Fort Vancouver" (Clarke 1905:184; Hussey 1957:49).

Structures may have been somewhat haphazard since they were meant to be temporary and because only a small crew was available to work on the new fort. Many of the few available men had to be sent back to Fort George to guard against a perceived threat from local Native groups (Hussey 1957:47) and it took until June 1825 to transport all goods and supplies from Fort George to Fort Vancouver (Hussey 1957:48). Additionally, the brig William and Ann, which landed at Fort George and was needed for a summer exploration of the Northwest coast, required significant repairs (Hussey 1957:29), so timber, ironwork, and a caulker were sent to Fort George from Fort Vancouver, taking even more time away from construction of the new fort (Hussey 1957:48). Over the summer of 1825, most of the crew were sent far and wide on expeditions leaving fort staff consisting solely of McLoughlin, a clerk, two servants, and seven common men (Hussey 1957:49). McLoughlin appeared to take the delays in stride since he knew that Simpson intended to eventually move the fort permanently to New Caledonia on the Fraser River (Hussey 1957:4; Lavender 1981:55; Erigero 1992:16), so was in no hurry to finish the fort completely.

Work on building the fort lagged, but McLoughlin wasted no time in starting his agricultural experiments. McLoughlin ordered crops planted immediately adjacent to the fort on the upper prairie, and a potato and vegetable field were established by the spring of 1825 (Erigero 1992:15). The spot was renowned for its fertility and for its beauty, and even Simpson seemed awed by this place, which he noted was "possessing so many 
natural advantages and where ornament and use are so agreeably combined" (Merk

1968:124).

On March 19, 1825 Governor Simpson christened the new fort. He writes in his journal:

At Sun rise mustered all the people to hoist the Flag Staff of the new Establishment and in presence of the Gentlemen, Servants, Chiefs \& Indians I Baptized it by breaking a Bottle of Rum on the Flag Staff and repeating the following words in a loud voice, "In behalf of the Honble Hudsons Bay Co. I hereby name this Establishment Fort Vancouver God Save King George the $4^{\text {th }}$ " with three cheers. Gave a couple of Drams to the people and Indians on the occasion. The object of naming it after that distinguished navigator is to identify our claim to the Soil and Trade with his discovery of the River and Coast on behalf of Gt Britain. If the Honble Committee however do not approve the Name it can be altered (Merk 1968:124).

Simpson then immediately departed Fort Vancouver leaving it in the hands of Chief Factor McLoughlin (Merk 1968:124) who set the fort buzzing with industry. Jedediah Smith, an American trapper, spent the winter of 1828-1829 at Fort Vancouver, and wrote that the fort employed blacksmiths, gunsmiths, carpenters, coopers, a tinner, and a baker (Hussey 1957:51). This number of craftspeople would surely require adequate housing and workspace, but any drawings or plans of the fort at this time are unknown. The crops planted in the spring of 1825 yielded 900 barrels of potatoes and $9 \frac{1}{2}$ bushels of peas in the first year (Hussey 1957:51). In 1826 McLoughlin planted the first wheat in Washington State, and also corn, and these crops did so well that he predicted Fort Vancouver would one day be able to supply the entire Columbia Department with all the corn and flour HBC posts needed (Hussey 1957:51). Apple trees and 
grapevines grew by 1828 (Hussey 1957:52), and livestock and other animals thrived at the Jolie Prairie. In 1825, over 100 horses grazed on the lower plain below the fort (Hussey 1957:53), and by November 1828 the prairie supported over 150 head of cattle (Merk 1968:301). By 1829, about 200 hogs, 50 goats, and various domestic fowl occupied the landscape (Hussey 1957:54). The four years of occupation at the first fort saw the landscape metamorphose into a bastion of European civilization and industry.

The Second (1829) Fort Vancouver

Simpson's plans to eventually move the Columbia Department headquarters from Fort Vancouver to New Caledonia were dashed when he travelled down the Fraser River in the fall of 1828. He wrote "I consider the passage down to be certain Death, in nine attempts out of Ten" (Hussey 1957:68-69). This realization, plus the finding that ships could travel the Columbia as far as Fort Vancouver (Hussey 1957:69), and McLoughlin's demonstration that the fort could support enough industry to make the Columbia Department no longer entirely dependent on supplies from England (Hussey 1957), made Simpson change his recommendation to the HBC Council. Simpson recognized the advantages of remaining in the current location, and in 1829 endorsed keeping the principal HBC post at Fort Vancouver. However, the fort on the bluff was extremely difficult to access from the river. Water was not readily available on the bluff and was transported twice a day by a wagon pulled by two oxen from the river (Clarke 1905:183; Hussey 1957:70). The impracticality of obtaining water, the non-existent need for defense against local American Indians, and the discredited fear of seasonal flooding of 
the entire lower plain clinched the decision to relocate Fort Vancouver in 1829 to the Jolie Prairie closer to the river (Erigero 1992:23).

The second Fort Vancouver served as an international hub and destination of American settlers until the Oregon Treaty of 1846, which decided once and for all the United States/Canadian boundary at the 49th parallel. Suddenly, Fort Vancouver became a British post on American soil, and to make matters worse, in 1849, the U.S. Army set up barracks on the high land overlooking the fort (Erigero 1992:199). An uneasy British and American cohabitation of the landscape lasted until 1860 when the HBC abandoned Fort Vancouver, and the remaining fort structures mysteriously burned to the ground in 1866 (Hussey 1957:160). In the 1940s and 1950s, National Park Service archaeologists re-located the 1829 Fort Vancouver, and the reconstructed fort now stands on its archaeological footprint, commemorated as Fort Vancouver National Historic Site.

\section{Project Area History}

While the second Fort Vancouver was successfully re-located, the first Fort Vancouver's location has been lost to time. Documentary evidence makes clear the first fort stood somewhere on the upper prairie, the project area for this study. This area now comprises two Vancouver, Washington residential neighborhoods, Hudson's Bay and Edgewood Park.

\section{Environmental context}

The upper prairie is on top of the bluff of the first terrace above the Columbia River floodplain, 130 feet above mean sea level. This terrace is of Pleistocene age, and according to McGee's Soil Survey of Clark County, Washington (1972:22), the terraces 
above the Columbia River are made up of the Lauren soil series. These soils are characterized by gravelly loam that is typically well-drained and is common on slopes up to $8 \%$. Characteristic native plants include Douglas fir (Psuedotsuga menziesii), grand fir (Abies grandis), Western red cedar (Thuja plicata), bigleaf maple (Acer macrophyllum), vine maple (Acer circinatum), salal (Gaultheria shallon), and various ferns (McGee 1972:22). Culturally significant species that possibly grew in the project area during the precontact era are huckleberry (Vaccinium parvifolium), camas (Camassia quamash), trailing blackberry (Rubus ursinus), and hazel (Corylus cornuta) (Hudson and Gall 2007:8). Today, this is a developed suburban area, cleared of original vegetation, with soils scraped and filled in places to level the ground for development. Vegetation currently present in the project area are mainly non-native species such as fruit trees, various grasses and forbs, and decorative plants in residential gardens, as well as native deciduous and conifer trees. Major drainage of the area is the Columbia River, about 1.5 $\mathrm{km}(0.93 \mathrm{mi}$.) due south, with a minor drainage, Burnt Bridge Creek, about $1.5 \mathrm{~km}(0.93$ mi.) northeast. Rainfall in the area averages $1.06 \mathrm{~m}$ (41.67 in.) per year (Clark County Washington 2020).

Environmental impacts in the project area are extensive and include the construction of neighborhood streets and historical and modern phases of construction for residences, commerce, and light industry. Gravel extraction from the bluff between East 5th and 6th streets has removed an unknown portion of land, but does not appear to extend to the terrace edge, possibly leaving the upland terrace intact (Hudson and Gall 2007:7). 


\section{Ethnographic and historical context}

Human presence at the project area and vicinity spans millennia. The area boasted an abundance of natural food sources in precontact times, and exploited game included beaver, deer, black bear, elk, duck, salmon, sturgeon, and steelhead. Periodic burning of the project area likely maintained an open grassland and prairie landscape (Deur 2012:10). Burning, used by American Indians for thousands of years, created much of the appearance of the grassland and forest landscape seen by early European explorers (Robbins 1997:31). Burning to encourage prairie land enhances growing conditions for such food staples as bracken ferns (Pteridium aquilinum) and camas (Camassia quamash and C. leichtlinii) (Robbins 1997:30). Burning practices contributed significantly to the bountiful quality of the landscape that European travelers so greatly admired and to the prospects for agriculture and pastureland they dearly coveted (Robbins 1997:55).

Indigenous peoples who lived near what is now Vancouver, Washington inhabited large villages along the Columbia River and its tributary streams (Deur 2012:20). They were of the Chinookan language group (Deur 2012:17), although Deur (2012:36) clarifies that the area was "principally, but by no means exclusively, occupied by people associated with the Cascades." European explorers and traders observed that the Jolie Prairie itself did not contain a permanent village site (Deur 2012:9), however, abundant resources in the vicinity allowed many groups to maintain permanent residence nearby. During the period of European contact, several Chinookan villages were located in the surrounding area (Deur 2012:17) on both the north and south shores of the Columbia River (Deur 2012:13). The site attracted seasonal migrations of people from all over what 
is now northwestern Oregon and southwestern Washington, causing the population to swell during harvest periods (Deur 2012:12). At peak harvest times for foods like salmon, big game, wapato, and camas, groups from non-resident tribes traveled from up to 400 miles away to exploit resources in the area (Deur 2012:11).

After the HBC established Fort Vancouver as a fur and mercantile trading post, archaeological and documentary evidence indicates that indigenous groups of various linguistic traditions engaged in trading at both the first and second forts (Deur 2012), in addition to working as HBC employees (Deur 2012:57). Indeed, the HBC situated Fort Vancouver in the midst of Native American villages and travel routes to maximize contact with indigenous groups (Deur 2012:1).

HBC occupation of the area forever changed the cultural landscape, devastating indigenous groups via disease and violence, paving the way for Euroamericans to populate the land (Deur 2012:2). The arrival of Europeans and fur traders brought an onslaught of diseases, decimating American Indian populations of the Oregon country with plagues like small pox and malaria (Boyd 1975:135-136). Censuses taken by the $\mathrm{HBC}$ in 1838 and 1845 reflect the drastic reduction in population of groups living near Fort Vancouver from disease and migration away from the area (Deur 2012:37). The mid-1800s saw a rise in American settlement, and the landscape became partitioned into donation land claims. Farms sprang up across the landscape, lasting into the mid-20th century. Farmland later disappeared as farmers sold their land to developers who once again transformed the landscape, this time into the dense residential neighborhoods seen today. 


\section{Notable project area structures, occupants, and events}

The project area landscape hosted occupation and use by American Indians for millennia. When the Hudson's Bay Company built Fort Vancouver in 1825, a major turning point occurred, with Europeans and Americans flooding the landscape and creating a sudden and lasting shift in the cultural, built, and natural environments. Today, the project area consists of two residential neighborhoods with a combined population of over 2,500 residents (City of Vancouver 2016), as well as numerous commercial establishments, two schools, and a national park. Since the construction of Fort Vancouver, the project area has hosted numerous notable structures, people, and events. Below, I mention a few relevant to this project.

\section{- HMS Modeste and Dundas' Folly}

During 1845-1847, the British Royal Navy anchored the HMS Modeste at Fort Vancouver. The Modeste, a relatively small, sail-powered, 560-ton sloop with a crew of 120 , possessed the agility to navigate the waters of the Columbia while exhibiting a substantial military presence (Mariners Museum 2019). The Modeste crew apparently built a structure near the site of the first Fort Vancouver on "Old Fort Hill" called Dundas' Folly or Dundas' Castle, named for and lived in by Modeste officer Adam D. Dundas (Erigero 1992:123). The structure was described in 1849 as being "on a high hill, the back ridge of the valley. It is a small octagon shaped log house with a pointed roof covered with canvass [sic], around an enclosure with shrubs planted" (Erigero 1992:123). After the Modeste left Fort Vancouver, the structure was apparently used by the HBC until at least 1858, and after that was occupied by American settlers (Erigero 1992:233). 
- General William S. Harney

A military presence in the project area continued with the occupation of General William S. Harney who commanded Vancouver Barracks during 1860, and led the U.S. Army's Department of Oregon from 1858 to 1860 (Erigero 1992:217). Harney was known for being aggressive and brutal toward anyone he considered inferior to himself, especially American Indians on whom he practiced vicious "sledgehammer warfare" (Shine 2019). While stationed at Fort Vancouver, Harney set up a homestead in the northern portion of the Edgewood Park neighborhood where Harney Elementary School now sits (Harney Elementary School 2019). During an interview for this project, one resident lamented Harney's commemoration at the school: "This was the outpost for Indian hunting. This was the Indian War capital. W.S Harney, Harney School, he was the Indian War chief. ... And that's the part that I don't like, is that we have Harney, and ... we have a history of the fort being there, military occupation in protection of settlers and trying to persecute Natives."

- Washington State School for the Deaf

The WSSD, founded as the Washington School for Defective Youth in 1886, changed location three times before the first campus building was built in 1889 at its current location in the project area at what are now Evergreen and Grand Boulevards (WSSD 1996:7). Over the last 130 years, campus buildings have been built, demolished, and expanded (WSSD 1996), and today the school stands as an important historical landmark in the neighborhood and the wider community.

- First Fort Vancouver commemorative sign 
In 1925, the city of Vancouver launched a months-long celebration of the centennial of Fort Vancouver that included parades, dramatic plays, a ground breaking ceremony for eventual reconstruction of the second (1829) Fort Vancouver, and the placement of signs commemorating events and places associated with Fort Vancouver (Meany 1925:113). One of these signs, which commemorates the first Fort Vancouver, was erected apparently near the eastern boundary of Vancouver Barracks at Century Point where it was still seen in 1953 (Figure 2.10).

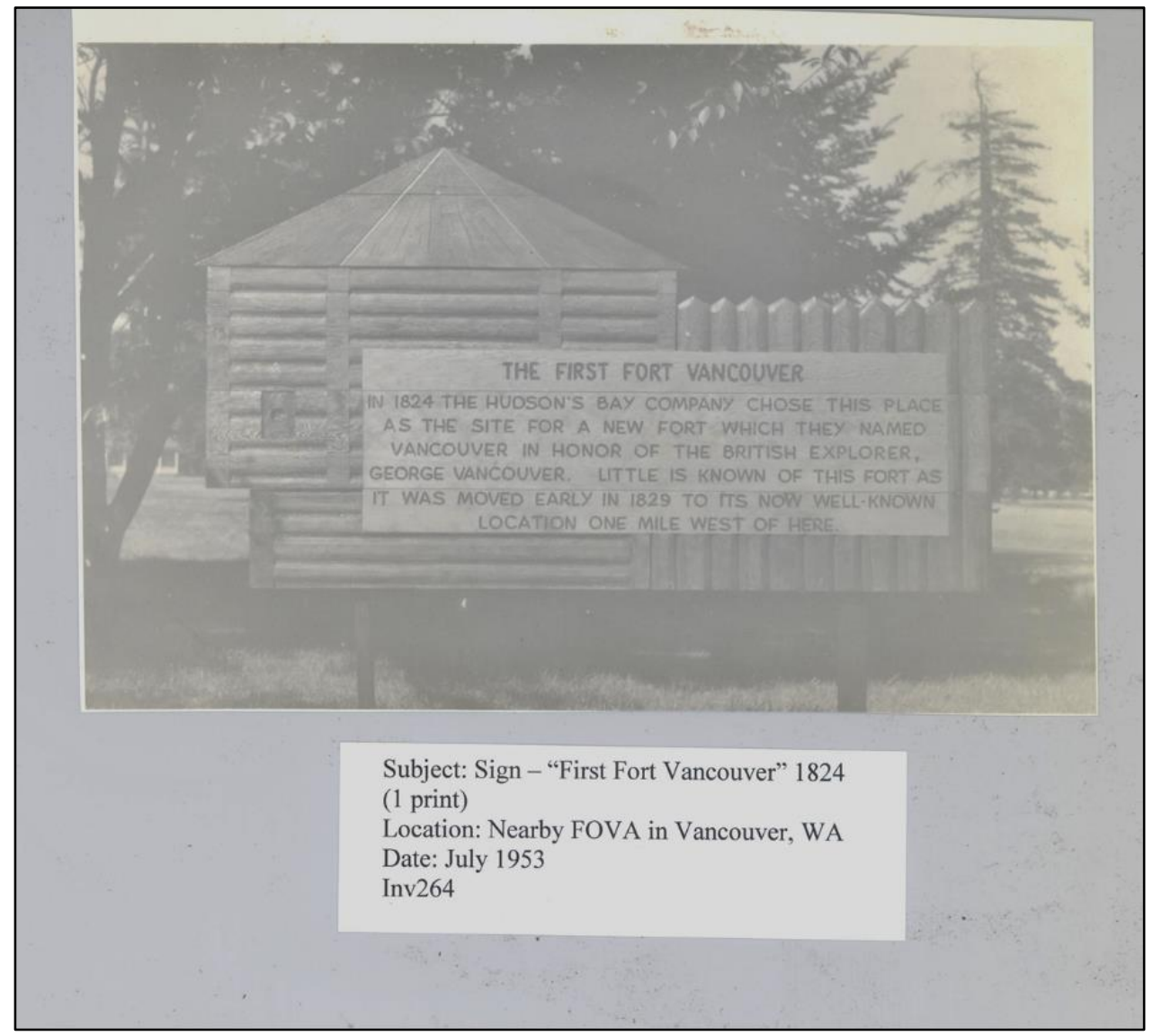

Figure 2.10 "The First Fort Vancouver" historical marker at Century Point, 1953. Courtesy National Park Service. 
At some point during the 1950 s or 1960 s, a new sign was made and placed at the WSSD designating that campus as the location of the first Fort Vancouver (Figure 2.11). My research did not locate records explaining why this sign was placed at the WSSD; however, it may simply have been a matter of convenience to place the sign on state land in an area surrounded by private property, and not necessarily due to evidence that the first fort existed in that exact spot. Even though the sign may not mark the exact location of the first Fort Vancouver, it has inspired neighborhood pride and curiosity about area history for decades, making it a significant historical marker in the project area.

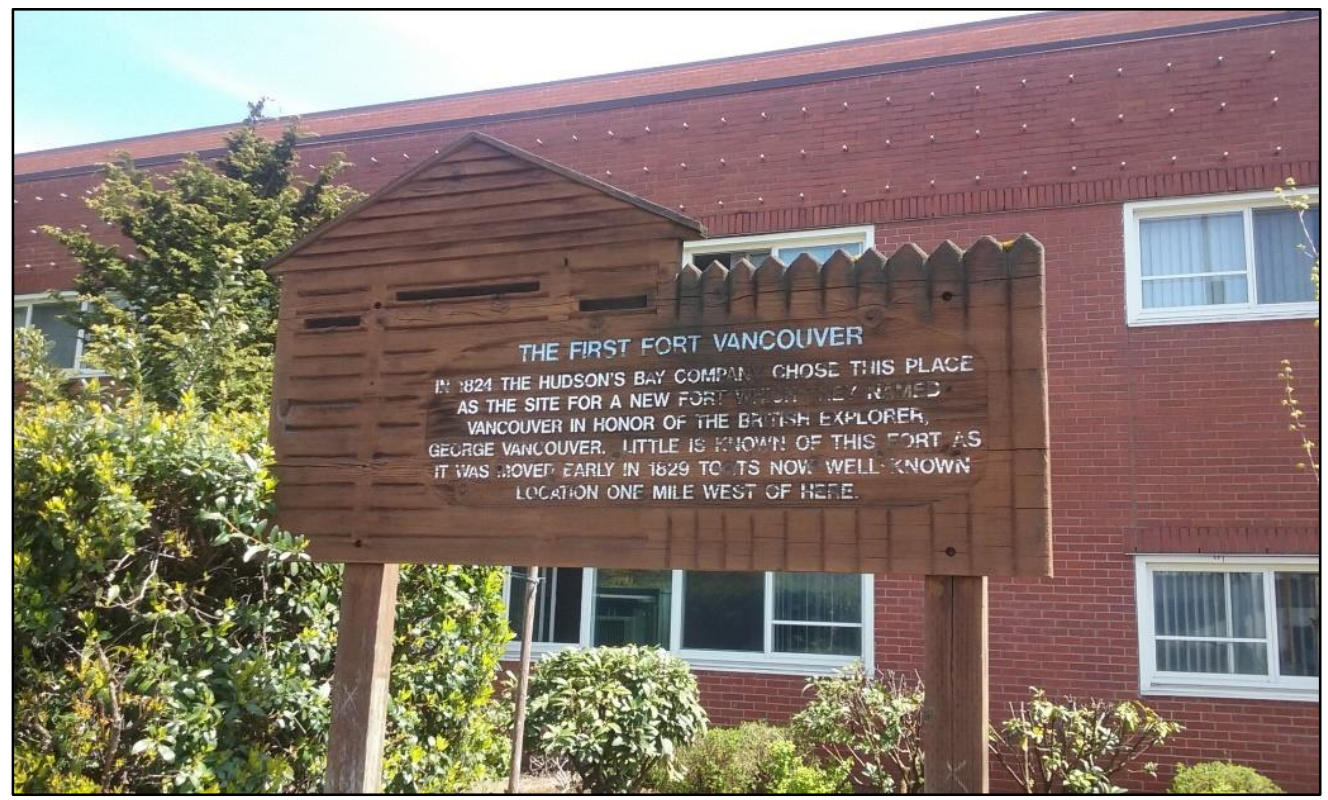

Figure 2.11 "The First Fort Vancouver" historical marker located on the campus of the Washington State School for the Deaf.

- $\quad H B C$ cemetery

A notable project area event related to Fort Vancouver involves burials inadvertently discovered at E 6th Street within one block west of Section 5 (Figure 6.2) 
of the project area, suggesting the presence of the HBC's first cemetery. In 1935, during excavation of a basement for home construction, workers discovered bodies buried in wooden caskets (Vancouver Columbian 1935a and 1935b). An article in the Vancouver Columbian (1935a) reports individuals to be "pioneer Washington residents" probably based on clothing and burial style, however the article does not suggest how this conclusion was made. Apparently, the remains were removed by the county coroner for examination, but my research, including inquiries at the Clark County Medical Examiner's Office, revealed no reports or information about what became of these remains. Neighborhood residents report that subsequent burials have been discovered over the years, however, any exposed human remains were apparently not reported to the authorities as they are not listed in Washington's cultural resources online database.

\section{- Kaiser Shipyards}

The 1940s saw a dramatic rise in population in the project area. During World War II, Henry Kaiser built one of his famous shipyards, Vancouver Yard, on the Columbia River directly below what is now the Edgewood Park neighborhood. Vancouver Yard manufactured 174 ships for the war effort and employed over 130,000 workers (Abbott 2018). The arrival of workers from all over the country caused Vancouver's population to triple during the first half of the 1940s (National Park Service 2017), and many of these workers lived in houses built by Kaiser in the project area, with some of these homes remaining today. Kaiser's claim to fame additionally includes establishing what is now known as the Kaiser Permanente healthcare system for shipyard employees and their families, and for the construction of the city of Vanport across the 
Columbia River in Oregon, to house 35,000 shipyard workers and their families (Abbott 2018). Kaiser's Vancouver Yard looms large in residents' interest in area history, perhaps because of the visual reminders of the shipyard in the form of neighborhood homes.

\section{Previous Archaeology}

To ascertain previous archaeological investigations within one square mile of the project area, I reviewed existing literature on file with the Washington Department of Archaeology and Historic Preservation's (DAHP) Washington Information System for Architectural and Archaeological Records Data (WISAARD) online database. I also reviewed one report (Gall and Lynch 2009) that does not, as of this writing, appear in WISAARD, which I received directly from the contract archaeology company Archaeological Services, LLC. It is a criminal offence to share locations and information concerning archaeological sites (RCW 42.56.300; Archaeological Resources Protection Act) so tables including site and project locations are provided to my thesis committee only, and not available for public viewing.

In addition to numerous projects and sites located at Fort Vancouver National Historic Site, archaeologists conducted 28 archaeological survey, testing, and monitoring projects (Table 2.1), and recorded 11 archaeological sites (Table 2.2) in a space of approximately one-square mile surrounding the project area. Sites mainly consist of historic-period artifact scatters and concentrations dating from the 19th to mid-20th centuries, as well as pre-contact lithic sites. Of archaeological projects and sites in the project area vicinity, three areas hold particular relevance to my project. 
First, Fort Vancouver National Historic Site (Fort Vancouver NHS) is located about one and one-quarter miles from the project area. Fort Vancouver NHS is one large archaeological site comprised of a multitude of individual loci containing artifacts from the pre-contact, Hudson's Bay Company, and U.S. Army periods. Numerous large- and small-scale archaeological investigations took place at Fort Vancouver NHS since the 1940s.

Second, in 2009, archaeologists glimpsed what lay underneath a significant portion of the Edgewood Park neighborhood during the Riverview Heights Sewer Extension project. Many of the streets south of Evergreen Blvd in the Edgewood Park neighborhood were mechanically excavated and archaeologically monitored, leading to the discovery of 19th- and 20th-century artifacts and the identification of three historicperiod archaeological sites (Gall and Lynch 2009).

Third, locals believe the first Fort Vancouver stood where the campus of the WSSD has been located since 1889 . This idea is perpetuated by the sign positioned at East $6^{\text {th }}$ Street and Grand Blvd on the WSSD campus designating this as the location of the first fort. In 1993, spurred by a proposed demolition project at the WSSD, Ellis (1993) summarized documentary evidence of the first Fort Vancouver. Ellis concluded that the documentary record was ambiguous concerning the exact location of the fort, and recommended archaeological testing of the area (Ellis 1993:14). Since the publication of Ellis' report, the WSSD campus has hosted several archaeological investigations, including archaeological testing of an original ground surface (Ellis et al. 1994:1), pedestrian surveys, shovel testing (Freed 2002; Hudson 2007a; Gall and Maceyko 2014), 
test excavations (Hudson 2007b), and monitoring of backhoe excavations (Cox 2008).

These investigations recovered no artifacts dating to the early 19th century, except for one glass bead found in highly disturbed soils (Cox 2008). Although this type of bead is potentially contemporaneous with occupation of the first Fort Vancouver, this artifact is not diagnostic evidence of the location of the fort because of the inability to assign provenience, the use of this bead type throughout the 19th century, and because similar beads are manufactured today.

Table 2.1 Archaeological survey and testing projects within approximately one square mile of the project area, not including Fort Vancouver NHS.

\begin{tabular}{|l|l|l|l|l|}
\hline $\begin{array}{c}\text { Reference } \\
\text { Number }\end{array}$ & Year & $\begin{array}{c}\text { Results of survey/ } \\
\text { testing }\end{array}$ & $\begin{array}{c}\text { Evidence of First } \\
\text { Fort Vancouver }\end{array}$ & \multicolumn{1}{|c|}{$\begin{array}{c}\text { Author/ } \\
\text { Affiliation }\end{array}$} \\
\hline 1691253 & 2018 & $\begin{array}{l}\text { Historic artifact } \\
\text { scatter }\end{array}$ & Negative & Thomas/CRC \\
\hline 1691607 & 2017 & Negative & Negative & Gilmore/WCRA \\
\hline 1691391 & 2017 & Negative & Negative & Colón/ASCC \\
\hline 1690872 & 2016 & Negative & Negative & Dubois/AINW \\
\hline 1690870 & 2016 & Sheet midden & Negative & Pattee/AAR \\
\hline 1685898 & 2015 & Modern debris & Negative & Gall/ASCC \\
\hline 1691085 & 2014 & Negative & Negative & Williams and Fagan/AINW \\
\hline 1690973 & 2014 & $\begin{array}{l}\text { Lithic scatter, lithic } \\
\text { isolate }\end{array}$ & Negative & Williams/AINW \\
\hline 1686242 & 2014 & $\begin{array}{l}\text { Pre-contact lithic } \\
\text { scatter, isolate }\end{array}$ & Negative & Williams and Fagan/AINW \\
\hline 1685217 & 2014 & Negative & Negative & Maceyko/ASCC \\
\hline 1352722 & 2009 & Negative & Negative & $\begin{array}{l}\text { Sharpe/US Army Corps of } \\
\text { Engineers }\end{array}$ \\
\hline 1352383 & 2009 & $\begin{array}{l}\text { Historic artifact } \\
\text { scatter }\end{array}$ & Negative & Chapman/AINW \\
\hline 1351194 & 2008 & Negative & Negative & Steele/AINW \\
\hline 1350460 & 2007 & Negative & Negative & Wilson/AINW \\
\hline 1350101 & 2007 & $\begin{array}{l}\text { Historic and modern } \\
\text { artifact scatter }\end{array}$ & Negative & Hudson/ASCC \\
\hline 1349911 & 2007 & Negative & Negative & Hudson/ASCC \\
\hline 1348186 & 2006 & Negative & Negative & Wilson/AINW \\
\hline 1344203 & 2002 & Negative & Negative & Freed/HRA \\
\hline 1684074 & 2001 & Negative & Negative & Finley/AAR \\
\hline 1345571 & 2001 & Negative & Roulette/AAR \\
\hline 1345410 & 2001 & Negative & & \\
\hline & & & Native & Nompson/PBS \\
\hline
\end{tabular}




\begin{tabular}{|l|l|l|l|l|}
\hline 1345618 & 2000 & Negative & Negative & DeLyria/ASCC \\
\hline 1345306 & 2000 & Negative & Negative & Mills/AINW \\
\hline 1345275 & 2000 & Negative & Negative & Solimano/AAR \\
\hline 1344792 & 1998 & Negative & Negative & Forgeng/AINW \\
\hline 1344777 & 1998 & $\begin{array}{l}\text { Pre-contact lithic } \\
\text { flakes and tools }\end{array}$ & Negative & Mills/AINW \\
\hline 1344740 & 1998 & Negative & Negative & Mills/AINW \\
\hline 1334660 & 1995 & $\begin{array}{l}\text { Historic artifact } \\
\text { scatter }\end{array}$ & Negative & Freidenburg/AHS \\
\hline
\end{tabular}

Table 2.2 Recorded archaeological sites within approximately one square mile of the project area , not including Fort Vancouver NHS.

\begin{tabular}{|c|c|c|c|c|c|}
\hline $\begin{array}{c}\text { Reference } \\
\text { Number }\end{array}$ & Year & Report Type & $\begin{array}{c}\text { Site/Project Name } \\
\text { and/or } \\
\text { Site Type }\end{array}$ & $\begin{array}{l}\text { Evidence of } \\
\text { First Fort } \\
\text { Vancouver }\end{array}$ & $\begin{array}{l}\text { Author/ } \\
\text { Affiliation }\end{array}$ \\
\hline CL01391 & 2018 & $\begin{array}{l}\text { Archaeological } \\
\text { Site Inventory } \\
\text { Form }\end{array}$ & $\begin{array}{l}\text { Grand Boulevard } \\
\text { Apartments. } \\
\text { Historic debris } \\
\text { scatter/concentration }\end{array}$ & Negative & $\begin{array}{l}\text { Colón/ } \\
\text { ASCC }\end{array}$ \\
\hline CL01353 & 2018 & $\begin{array}{l}\text { Archaeological } \\
\text { Site Inventory } \\
\text { Form }\end{array}$ & $\begin{array}{l}\text { Historic debris } \\
\text { scatter/concentration }\end{array}$ & Negative & $\begin{array}{l}\text { Thomas/ } \\
\text { CRC }\end{array}$ \\
\hline CL01066 & 2014 & $\begin{array}{l}\text { Archaeological } \\
\text { Site Inventory } \\
\text { Form }\end{array}$ & $\begin{array}{l}\text { Kaiser Hospital. } \\
\text { Historic debris } \\
\text { scatter/concentration }\end{array}$ & Negative & $\begin{array}{l}\text { Williams/ } \\
\text { AINW }\end{array}$ \\
\hline CL01042 & 2014 & $\begin{array}{l}\text { Archaeological } \\
\text { Site Inventory } \\
\text { Form }\end{array}$ & Pre contact isolate & Negative & $\begin{array}{l}\text { Williams/ } \\
\text { AINW }\end{array}$ \\
\hline $\begin{array}{l}\text { Temporary } \\
\text { site number } \\
\text { ASCC } \\
09556-1\end{array}$ & 2009 & Results Report & $\begin{array}{l}\text { Riverview Heights } \\
\text { Sewer Extension. } \\
\text { Historic debris } \\
\text { scatter/concentration }\end{array}$ & Negative & $\begin{array}{l}\text { Gall and } \\
\text { Lynch/ } \\
\text { ASCC }\end{array}$ \\
\hline $\begin{array}{l}\text { Temporary } \\
\text { site number } \\
\text { ASCC } \\
09556-2\end{array}$ & 2009 & Results Report & $\begin{array}{l}\text { Overland Car Site. } \\
\text { Historic debris } \\
\text { scatter/concentration }\end{array}$ & Negative & $\begin{array}{l}\text { Gall and } \\
\text { Lynch/ } \\
\text { ASCC }\end{array}$ \\
\hline $\begin{array}{l}\text { Temporary } \\
\text { site number } \\
\text { ASCC } \\
09556-3\end{array}$ & 2009 & Results Report & $\begin{array}{l}\text { Blue Marble Site. } \\
\text { Historic debris } \\
\text { scatter/concentration }\end{array}$ & Negative & $\begin{array}{l}\text { Gall and } \\
\text { Lynch/ } \\
\text { ASCC }\end{array}$ \\
\hline CL00805 & 2008 & $\begin{array}{l}\text { Archaeological } \\
\text { Site Inventory } \\
\text { Form }\end{array}$ & $\begin{array}{l}\text { WA School for the } \\
\text { Deaf. Historic debris } \\
\text { scatter/concentration }\end{array}$ & Negative & $\begin{array}{l}\text { Cox } \\
\text { /AINW }\end{array}$ \\
\hline CL00727 & 2007 & $\begin{array}{l}\text { Archaeological } \\
\text { Site Inventory } \\
\text { Form }\end{array}$ & $\begin{array}{l}\text { Blue Bird Ridge. } \\
\text { Historic debris } \\
\text { scatter/concentration }\end{array}$ & Negative & $\begin{array}{l}\text { Hudson/ } \\
\text { ASCC }\end{array}$ \\
\hline
\end{tabular}




\begin{tabular}{|l|l|l|l|l|l|}
\hline CL00486 & 1998 & $\begin{array}{l}\text { Archaeological } \\
\text { Site Inventory } \\
\text { Form }\end{array}$ & $\begin{array}{l}\text { Columbia View } \\
\text { Condominiums. Pre- } \\
\text { contact lithic material }\end{array}$ & Negative & $\begin{array}{l}\text { Mills/ } \\
\text { AINW }\end{array}$ \\
\hline CL00261 & 1980 & $\begin{array}{l}\text { Archaeological } \\
\text { Site Inventory } \\
\text { Form }\end{array}$ & $\begin{array}{l}\text { Original Fort } \\
\text { Vancouver Site }\end{array}$ & Unknown & Anonymous \\
\hline
\end{tabular}

Previous archaeological examinations in the project area have been conducted in the course of contract archaeological work. These investigations accessed public property, as in work done at the WSSD and the sewer extension project, or employed limited subsurface testing for clients on privately-held land interested in building housing structures. Methods used in my project served as alternatives to standard contract archaeology practices to fill in this gap in the history of Vancouver and of the fur trade. The unique public archaeology aspect provided by my project allowed for the exploration of previously inaccessible areas, namely private property in residential neighborhoods, greatly increasing the land area tested to locate material remains of the first Fort Vancouver. 


\section{Chapter 3: Theoretical Approaches}

Because of the complexities of working with homeowners on private property, the goals of this project relied heavily on the incorporation of public archaeology used not only as a disciplinary practice but as a theoretical position (Richardson and AlmansaSánchez 2015:195). The term public archaeology was first used in conjunction with cultural resources management (CRM) in the 1970s, indicating salvage efforts for archaeological sites threatened by development, for the benefit of the public at large (Matsuda and Okamura 2011:2) and in compliance with federal laws such as the National Historic Preservation Act of 1966, the National Environmental Policy Act of 1969, the Archaeological Resources Protection Act of 1979, and the Native American Graves Protection and Repatriation Act of 1990 (Colwell 2016:114). The CRM use of the term remains (which I call standard CRM), but public archaeology as a discipline and theoretical perspective is associated today with a wide range of meanings and practices. I used public archaeology theory for this project underpinned by theoretical approaches from education, archaeological ethnography, pragmatism, site interpretation, and place attachment. Throughout this thesis I refer to the people I interacted with as stakeholders, communities, and the public, and I use Jameson and Baugher's (2008:5) definition of these terms as groups of people linked by residing in the same locality, or sharing a common interest, likeness, or identity.

\section{Public archaeology}

The most common definition of public archaeology involves the engagement of archaeologists with defined publics for the purpose of benefitting interpretation in 
archaeology and making a positive impact on society. Public archaeologists realize that the public's attitude toward archaeology matters, and that community-based partnerships are the best way to benefit both the public and the discipline (Derry 2003a:185; Malloy 2003:ix; Little and Shackel 2007; Jameson and Baugher 2008:4). Often, archaeological law is determined, enforced, and practiced by hegemonic powers (Soderland 2012:37). With its strong relationship with Indigenous archaeology, the field of public archaeology seeks to divest archaeology of its colonial and Western-centric tendencies (Atalay 2006:280) and to connect archaeological data with descendants (Colwell 2016:114) and local communities (Wright 2015).

Involving the public in archaeological research enriches archaeological interpretation and provides enhanced data concerning patterns, change, and continuity in use of material culture over time and space (Brown 1973; Montell and Bogart 1981; Costello 1998; Cubitt 2007; Moshenka 2007; Praetzellis et al. 2007; Garrison 2015); in addition, the public becomes engaged and empowered in exploring and interacting with their own heritage (Little 2007b). Proponents of public archaeology cite numerous benefits of archaeologists reaching out to the public through community-based projects (Gadsby and Chidester 2007:238; Little 2007a:13) which actively involve community members in archaeological research. Community-based projects strive to include and empower communities in the search and analysis of their own histories (McDavid 2007) and the histories of the places they live. Throughout the project I solicited input and participation from residents wherever possible in an effort to encourage communitybased engagement with area history and archaeology. 


\section{Education theory}

Theoretical underpinnings of public archaeology stem from two main realms, archaeology and education (Cole 2015); most of the time it seems as if a combination of a variety of approaches from these realms is used to appropriately address the goals and needs of community archaeological projects. A few education-based approaches are relevant to my project. In the deficit model, the expert (e.g. an archaeologist) fills in a lack of knowledge in the listener about a topic, archaeology, or archaeological projects (Merriman 2004a; Holtorf 2007; Matsuda and Okamura 2011; Conforti et al. 2013). The more inclusive multiple perspective model engages the public in a way that values all ways of understanding and is meant "to encourage self-realisation, to enrich people's lives and stimulate reflection and creativity" (Merriman 2004a:7). The multiple perspectives approach is a way to democratically engage in research of the past, letting all stakeholders interact with the research in a way that is meaningful to them personally (Merriman 2004a:7; Holtorf 2007; Matsuda and Okamura 2011). Over the past 70 years, more and more archaeologists have advocated for increasingly democratic and inclusive approaches in public archaeology (Moser et al. 2002; Merriman 2004b; Richardson and Almansa-Sánchez 2015) to not only improve the image of archaeology to increase public support (Holtorf 2007:150), but to stimulate cooperation between archaeologists and the public for the benefit of both (Wheeler 1956; Fritz and Plog 1970; Baba 2000:21; Robbins and Robbins 2014; Richardson and Almansa-Sánchez 2015). Some archaeologists go even farther to say that archaeology's most important goal should be to serve the public (Matsuda 2016). 
One of my project goals was to increase knowledge and awareness about archaeology in members of the community. The deficit model, called by some the empty vessel approach, was one tactic I found appropriate at times, but a constructivist approach (Bartoy 2012) is perhaps a more democratic way to look at education. "Fact is... constructed from evidence" (Bartoy 2012:554), and in constructivism the learner is actively involved in constructing their own understanding of the subject (Bartoy 2012:554). Meaning is constructed from people's own perceptions and experiences (Copeland 2004:134), and my project served as an archaeological platform for community members to add to and question previous notions and build on their understanding of the meaning and importance of area heritage and archaeology.

During this project, the interview process and archaeological excavation provided active learning situations in which community members and I learned from and taught each other (Bartoy 2012:554) in a scaffolding knowledge approach (Bartoy 2012:555). Scaffolding is the idea that everyone has a unique knowledge base developed through their experiences in the world they live to which new knowledge is added, ideas are changed and modified, and information is synthesized and understood. Through the support of teachers and peers, knowledge is scaffolded, or built, on top of previous knowledge adding to and changing the entire structure of knowledge for both the teacher and the student (Bartoy 2012:555-556), or, in this case, archaeologist and community members. Throughout the project process, participants and I taught each other, adding to our knowledge of the history of the project area, of the thoughts and feelings of neighborhood residents, and of the discipline of archaeology. 
My project necessitated the education of and cooperation with Vancouver neighborhood residents to take place, but I went beyond mere cooperation to actual collaboration with the public (Ervin 2005; Lassiter 2008; Spoon 2014). With collaboration, archaeology becomes a tool through which community members can scaffold knowledge, making their connections to the past and to each other clearer. I strove to ensure affected groups understood their role and importance as stakeholders in, and stewards of, the history and archaeology of the place they live, work, and enjoy, so that they felt part of the process and results of the study. The benefits of collaboration are seen in research projects that used similar methods to those I used, such as Flannery's (2013) integration of data from oral history interviews to expand the story of a Kentucky railroad logging camp settlement; Barton and Markert's (2012) collaborative work with descendent and vested communities to better understand the history of a New Jersey town; and Wright's (2015) work with resident communities to encourage stewardship of archaeological sites on private property.

\section{Archaeological ethnography}

It is through connections between the archaeological study of material culture and the study of documentary records that bring the past to life through "the complementary nature of history and archaeology" (Deetz 1988:363). I would further argue that the often-untapped resource of living people in archaeological research adds a critical dimension to this relationship that deepens and legitimizes our studies. Ethnography is the study of the ways of life of specific groups of people (Edgeworth 2006:xii; Hollowell and Mortensen 2009:3, citing Angrosino 2005), and the voices of a wider community are 
heard through ethnographic devices like interviews and surveys. McGuill (2010:471)

makes an important distinction between ethnoarchaeology and archaeological

ethnography: ethnoarchaeology uses ethnographic methods to supplement archaeological

interpretation, while archaeological ethnography unites ethnographic and archaeological

practices to make archaeology more relevant and accountable to diverse communities

(see also Hamilakis and Anognostopoulos 2009). Decades ago, archaeologists began

realizing archaeology needed to evolve to survive: "archaeology will become applied

anthropology or it will become nothing" (Kelly 2003:vii), and I believe archaeology as

applied anthropology is public archaeology. Archaeology that involves and includes

stakeholders in research and interpretation, where the viewpoints of non-experts are

valued (Thomas 2004:196), and is united with ethnographic study, has the power to make

archaeological research much more meaningful and significant to communities of non-

archaeologists than archaeological research on its own.

Pragmatism

Many view the philosophy of pragmatism as a crucial underpinning to public archaeology, because it makes the discipline useful for measuring the value of archaeology by its relevancy and ability to solve problems in the present day (Mrozowski 2012:239). Archaeology has long been directed by government entities and elite specialists with control over which past is considered legitimate and how the past is studied (Klimko 2004:160; Thomas 2004:191). Pragmatism in public archaeology remediates some of archaeology's colonialist tendencies and isolationism (Kehoe 2012:537) by employing a more democratic structure in which interpretation includes the 
viewpoints of many stakeholders (Hodder 1991:13) producing collaborative, multivocal outcomes (Collwell-Chanthaphonh 2012:275-277). In addition, pragmatism requires archaeology to shift from acting as an "unquestioned authority" to facilitating opportunities for diverse stakeholders in exploring the past (Thomas 2004:197). In this project, I put pragmatism into practice by presenting opportunities for residents to connect with archaeology and to make connections between people in the present and people in the past. I hoped these connections would result in increased interest and pride in area history, and in archaeological research and its role in society, benefitting residents and the field of archaeology through support and stewardship.

\section{Interpretive theory}

Interpretation of archaeology, area history, and material culture played a significant role throughout this project in educating the community, and, more importantly, helping people make "intellectual and emotional connections to the meanings and significance" (National Park Service 2014) associated with archaeology, history, and artifacts. Opportunities for people to make personal connections to cultural resources may result in motivation to act as stewards in the protection of these resources (Derry 2003b:26) and good interpretive skills can facilitate not only intellectual connections, but also emotional connections to archaeological resources (Derry 2003b:19). Derry (2003b:27) advises that "[a]rchaeologists trained as anthropologists would be wise to revisit their ethnographic skills" to use interpretation more adeptly with the community. Effective interpreters recognize that audience members come from varying backgrounds, ways of learning, life stages, etc. (National Park Service 2014), 
necessitating unique interpretive approaches for individual participants. In my project, I recognized that some residents felt emotional connections to area history, while others were fascinated by artifacts, and still others expressed intrigue with archaeological methods. An understanding of interpretive theory was critical in adjusting my approach to each individual to facilitate meaningful connections leading to feelings of stewardship and protection of the fragile archaeological resources in the project area.

\section{Place attachment theory}

A cornerstone of this project stems from place attachment theory. The idea of place attachment comes from environmental psychology (Wright 2015:214) and has been defined as "the bonding of people to places" (Low and Altman 1992:2). I wanted to explore how attached project participants felt to the place where they live, and if attachment feelings were at all affected by this project and its use of archaeology to gain further understanding of the history of where they live. In other words, I wanted to find out if being involved in an archaeological project in their neighborhood and, more intimately, on their own property, made residents feel more attached to this place and how it connects them to people in the past. Far-reaching ancestral ties are not a prerequisite for place attachment; simply experiencing a place in any number of ways (Wright 2015:214) like living, working, playing, or visiting can foster feelings of attachment.

Place attachment may lead to place identity, in which a place becomes part of one's identity (Wright 2015:214) and it is true that judgements about a person's values, beliefs, and personality are often made based on where that person spends time. Gifford 
(2014:543) posits that place, as in anywhere one spends time, helps form one's identity, and that "[p]erson-place influences are both mutual and crucial. We shape not only buildings but also the land, the waters, the air, and other life forms - and they shape us." Identity is formed not just from our cultural identities, but from many dynamic factors including place (Wright 2015:213).

The archaeological record shows us that places are often inhabited by successive populations of people over long periods of time (Wright 2015:214), and this is true for my project area. American Indians occupied this landscape from time immemorial before the Hudson's Bay Company, white settlers, and now the current modern population appeared, and all these populations are tied to each other because of their presence at this particular place. Identity is one of the leading factors in people's interest in heritage and the past, and curiosity and awareness of past people, events, and places of heritage is often piqued by things that people identify with-- ancestral ties, similar experiences, and shared interests. Wright (2015:213) adds, "identities based on shared connections to place comprise an important and under-appreciated dimension of building, managing and preserving heritage." Archaeological projects have the power to activate identification with people in the past (Uunila 2003:39), and this bond can become even stronger in the intimate setting of one's own property (Brown 2012:2). The power of excavating material culture that was last touched by someone occupying a place sometime in the past (Uunila 2003:38), whether it was 50 years ago or ten thousand years ago, creates a sense of closeness and familiarity. When a place becomes part of one's identity, my hypothesis is, 
one is much more likely to be interested in the history of that place, and will more likely want to protect and preserve the cultural resources found there.

Using archaeology to heighten feelings of place attachment benefits residents, and it aids archaeology, too. Gifford (2014:544) includes place attachment in his list of factors that influence behaviors, saying "[i]f individuals have a strong attachment to a place, they probably want to protect it" (Gifford 2014:547). While Gifford is referring to “proenvironmental" behaviors (Gifford 2104:544), the idea can be applied to protection of archaeological and heritage sites as well. Relationships between people in the present with those in the past "may be marshalled to encourage new appreciation for and stewardship of the past represented in the archaeological record" (Wright 2015:215). In the search for the first Fort Vancouver I strove to bring attention to the project area's long history of habitation, and the ties based on place that bind people together stretching back thousands of years, in the hope of broadening appreciation for history and archaeology, and increasing interest in the protection of cultural resources, whether the first fort is found or not. 


\section{Chapter 4: Methods}

Three objectives guided this research: 1) an investigation in the use of public archaeology methods to search for the first (1825) Fort Vancouver; 2) an ethnographic analysis of whether participation in an archaeological project leads to change in how residents feel about archaeology, heritage, and place attachment; and 3) an exploration in the use of specific public outreach methods to gain support for archaeological research. I intended that the analysis and outcomes of the project would lead to insights into how public archaeology may be used to make archaeology relevant and meaningful to specific communities affected by archaeological research, namely, those living on top of or near archaeological sites. To achieve these objectives, I used four complementary methods: documentary research, public outreach, ethnographic research, and archaeological fieldwork.

\section{Documentary Research}

Documentary investigations included research on the first (1825) Fort Vancouver, the history of the project area, and the properties on which excavation occurred. Fort Vancouver NHS has an immense collection of materials on Fort Vancouver history and material culture, and the second (1829) Fort Vancouver is very well documented. The record related to the first fort, however, is somewhat scanty, making documentary research challenging. Primary sources that I referenced on the first fort included contemporaneous diaries, letters, and sketches available at Fort Vancouver NHS, and $\mathrm{HBC}$ records available from the HBC Archives in Winnipeg, Manitoba, preserved on microfilm held at Fort Vancouver NHS. Secondary sources included Hussey’s (1957) 
history of Fort Vancouver, Erigero's (1992) historical research on the cultural landscape of Fort Vancouver, and Merk's (1968) annotated printing of the journal of HBC governor George Simpson.

To discover the history of the project area I investigated historic USGS maps online; aerial photographs, Donation Land Claim (DLC) and Sanborn maps at the Clark County Historical Museum and the Fort Vancouver Regional Library; informational interviews with long-time neighborhood residents; and research books on Clark County history. I also spent one day in the archives at the Washington State School for the Deaf looking through historical documents and newsletters from that school.

Understanding the residential history of properties where I excavated was crucial for artifact and site analysis, so I attempted to track down property ownership history through DLC maps and in historical Polk City Directories at the Fort Vancouver Regional Library. I combined this documentary information with stories about past residents and property use that emerged during the ethnographic research, enhancing interpretation of artifacts and sites.

I summarized, compared, and analyzed documentary evidence forming the foundation for the project. Research on the history of the first fort helped narrow down the search area and aided in recognition of the types of material culture that would indicate presence of the first fort. Study of the project area and excavation properties gave information on the appearance, changes, and usages of the landscape over time, aiding the interpretation of artifacts found during the project. Information from the documentary record also helped in formulating questions asked during ethnographic 
interviews and provided necessary background information included in public presentations.

\section{Public Outreach}

In 1996, the Society for American Archaeology (SAA) adopted eight Principles of Archaeological Ethics, and Principle No. 4: Public Outreach and Education states that "[a]rchaeologists should reach out to, and participate in cooperative efforts with, others interested in the archaeological record with the aim of improving the preservation, protection, and interpretation of the record" (SAA 1996). To this archaeology-centric goal I add that sharing our work with the public makes archaeology relevant and meaningful for the benefit of communities affected by our research (Little 2002a; Shackel and Chambers 2004; Rockman and Flatman 2012; Skeates, et al. 2012; Wright 2015). Social media, elementary classroom visits, public presentations, and newspaper articles are ways I reached out to the public, enriching both the archaeological project and the community.

\section{Social Media}

In February 2018, I started a blog at FirstFortVancouver.com, called "Searching for the First Fort Vancouver" (Clearman 2017a). The past two decades have seen a significant increase in blogging in archaeology (Perry 2015). I chose this online medium as a way to share my research with stakeholders beyond the neighborhoods associated with the project area to reach a diverse and perhaps far-flung audience (Morgan and Winters 2015). My blog serves as a forum for sharing news and results of the project, and includes posts about archaeological methods and project area history to provide a 
foundation on archaeology and background information for the project (Figure 4.1). This way, even someone who knows little about archaeology might appreciate the details of the project, and to this end, the initial posts (numbers 1 through 8 ) are about the science and practice of archaeology, followed by history of the fur trade and of Fort Vancouver. Later posts chronicle progress of my thesis project and provide deep dives into specific artifact types relevant to the first Fort Vancouver. Sharing my work and research via the blog serves to educate and inform online stakeholders; however, it goes beyond simply dispensing information. It offers access into the study of archaeology to those who may never have first-hand experience in archaeology (Morgan and Winters 2015), providing an egalitarian mode of sharing archaeology with a variety of communities. 


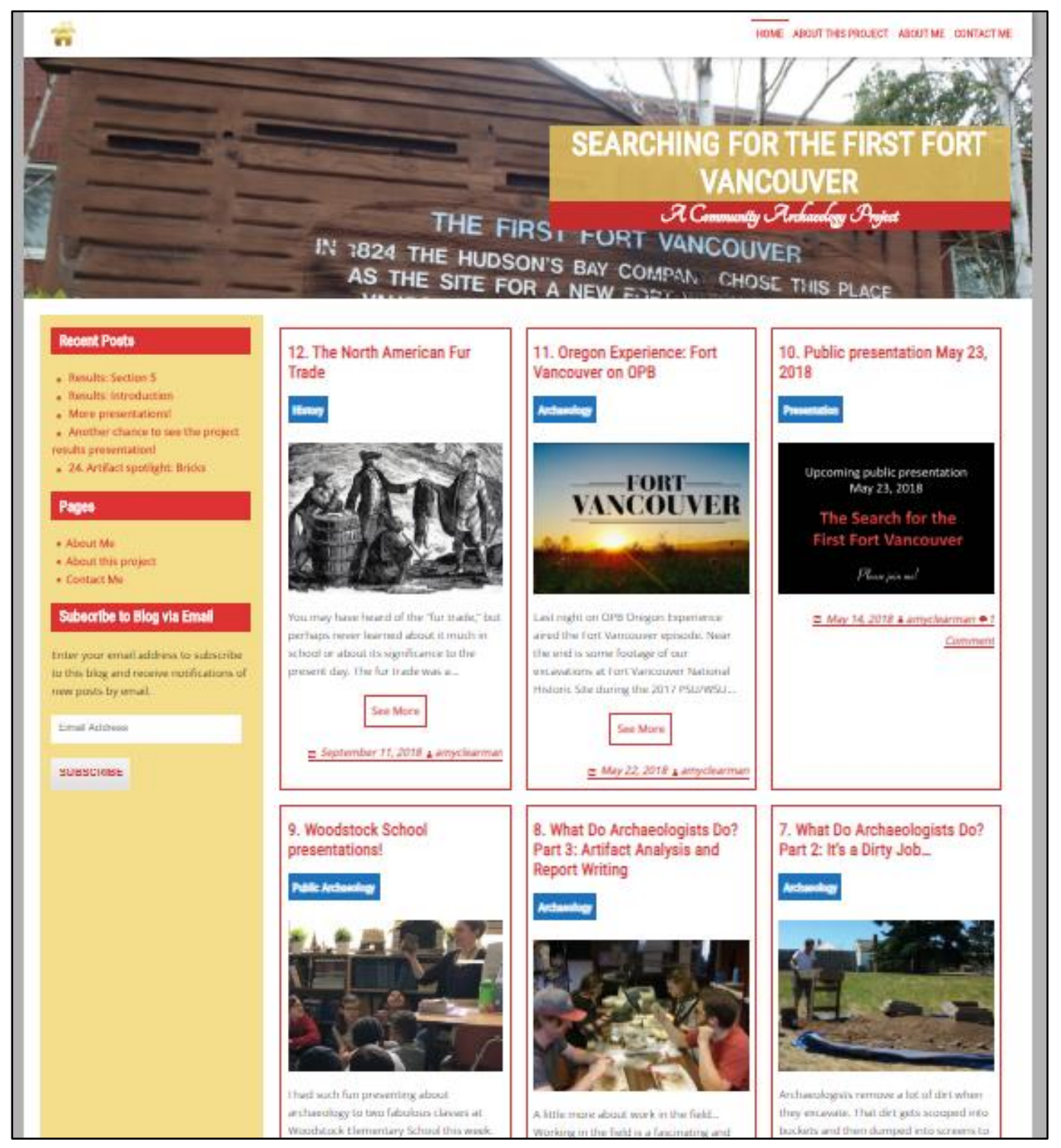

Figure 4.1 Screenshot of the blog "Searching for the First Fort Vancouver"

\section{Elementary school presentations}

I developed a program introducing archaeology to elementary school children to increase visibility of my project in the project area through promotion at a neighborhood school, Harney Elementary School. Daehnke (2002:2) opines that public outreach which stresses how archaeology is done - the methods of archaeology - is perhaps a more effective model for promoting the value of archaeology to the public than simply 
explaining the results of archaeological research, and this is perhaps most true for children. My educational program consisted of a slide show presentation explaining what archaeology is and what archaeologists do, followed by a hands-on activity in which the students and I discussed a suite of artifacts from the Fort Vancouver teaching collection. Students looked at and handled the artifacts and we talked about what the artifacts might be, what they might have been used for, who might have used them, and, as a collection, what they might tell us about an archaeological site. Using this format and following a constructivist approach (Bartoy 2012), my intention was to stretch my audiences' minds from thinking of archaeology as merely "treasure hunting" to recognizing ways that archaeology informs us about the lives of people in the past. I aimed to instill in these students (and their teachers) ways that archaeological research is relevant and meaningful to them personally by guiding them in making connections between their lives and the lives of those who lived before. The intent then, was that recognition of the value of archaeological research might pass from the schoolchildren to their parents and other neighborhood residents to increase support of and participation in my project.

\section{Public presentations and newspaper articles}

I held two public presentations at the Fort Vancouver Visitor Center, one in May 2018 to introduce the project to the community, and one in March 2019 to present project results. Newspaper articles about my project in the Columbian newspaper advertised the presentations. 


\section{Ethnographic Research}

Ethnographic research was intended to gain insight into how residents and the wider public feel about heritage, archaeology, and place attachment, as well as to obtain information about the area and its history. Data collection methods included ethnographic and informational interviews and anonymous ethnographic surveys. Since the research involved human subjects, I applied to and received approval from Portland State University's Human Subject Research Review Committee of the Institutional Review Board (Appendix B) to ensure all proper ethical procedures were followed and to minimize risk to participants. Below I review the Institutional Review Board application process, a research study I conducted prior to the thesis project, participant recruitment strategies, survey and interview methods, ethnographic data analysis methods, and ways that I returned my research to the community.

\section{Institutional Review Board}

Ethnographic methods necessitated application to PSU's Human Subject Research Review Committee of the Institutional Review Board (IRB). The IRB reviews university student and faculty research projects to ensure research methods comply with state and federal regulations on the ethical treatment of human and animal research subjects, that the rights and welfare of research subjects are protected, and that any risks from participating in research studies are reasonably outweighed by benefits from participation. In my application I identified three possible risks to participants in this study: invasion of privacy to the subject or family, breach of confidentiality, and economic risk. I demonstrated to the IRB that I would minimize these risks by: de- 
identifying interview and archaeological data to ensure confidentiality; providing all participants with informed consent forms prior to participation to confirm that they understand risks, benefits, rights, and responsibilities; and, if an archaeological site was found on private property, the exact property location would not be revealed except to my thesis committee and to archaeologists working in Washington State through restricted access to the Washington Information System for Architectural and Archaeological Records Data (WISAARD). This last measure not only complies with Washington State law (RCW 42.56.300), it protects homeowners who do not wish to reveal they have an archaeological site on their property, and protects the archaeological resources from potential looting and relic hunting.

\section{Previous Research Study}

Prior to my thesis research, I conducted a short study as part of coursework at Portland State University. For the study, I prepared a Needs Assessment for the Hudson's Bay Neighborhood, a neighborhood in my project area, to gain insight into residents' feeling about heritage and archaeology in their neighborhood (Clearman 2017b). I conducted a key consultant interview with the chair of the neighborhood association and a focus group with five neighborhood residents. This research provided essential insight into the project area, and the preliminary fieldwork offered critical access to, trust of, and information about the study community (LeCompte and Schensul 2010:160).

\section{Recruiting Research Participants}

Recruitment was critical since the project could not occur without interview and excavation participants. I sought participants for informational interviews, ethnographic 
interviews, and archaeological excavation and I used recruitment methods that were intended to reach a large number of neighborhood residents. Use of my credentials as a graduate student at PSU and a graduate research assistant at Fort Vancouver NHS helped facilitate connections with the community (Atalay 2012:102) through my association with legitimate and trusted institutions. To recruit participants, I used the following methods: I contacted neighborhood association leaders in both project area neighborhoods and attended a neighborhood meeting to introduce myself and the project; my contact information appeared in a May 2018 Columbian article about my project (Vogt 2018); at a public presentation on May 23, 2018, I announced the need for project participants for interviews and excavation; in October 2018, I mailed hand-addressed letters to 150 Edgewood Park homeowners (Appendix C) and renters (Appendix D); and I received word-of-mouth referrals from residents.

\section{Ethnographic Surveys}

I administered anonymous ethnographic surveys with audience members at two public presentations to obtain data concerning the wider population's feelings and understanding of heritage and archaeology. Surveys gathered both quantitative data mainly on the demographics of survey participants, and qualitative data to gather context, meaning, and motivation concerning people's thoughts on heritage and archaeology (Schensul and LeCompte 2013:155). I pilot-tested the survey with two volunteers to review flow, sequence, length, comprehension, and language (Schensul and LeCompte 2013:266). I administered the first survey (Appendix E) at my public presentation in May 2018 before the start of interviews and excavation. I administered a second survey 
(Appendix F) at the second public presentation in March 2019 at the end of the project to get data on whether a local archaeology project had any effect on how the wider public feels about heritage and archaeology. I distributed an informed consent notice to each survey participant (Appendix G), and I used a Microsoft Excel spreadsheet for calculating descriptive statistics.

\section{Interviews}

Interviews took place at residents' homes, in the library and collections facility at Fort Vancouver NHS, and at a local coffee shop. Participants received and signed an informed consent document (Appendix G) and I recorded interviews on an Olympus digital voice recorder. I fully transcribed the interviews using Express Scribe Transcription software, assigned a code to each one for confidentiality, and stored each in a secure file on my personal computer. Transcripts remain confidential and are not included in any appendix of this document, however, copies with names and addresses removed are available to my thesis committee. I divided interviews into two types. First, what I call informational interviews were treated as life histories (Yow 2005:225), in which participants recounted stories and experiences specifically about their lives in the project area beginning in the 1940s. Second, what I refer to as ethnographic interviews (Yow 2005:9) captured information regarding how involvement in this project may have changed residents' feeling about archaeology, heritage, and place attachment.

\section{Informational interviews}

I conducted informational interviews with area residents who lived in the Edgewood Park neighborhood since childhood beginning in the 1940s. I prepared a list of 
13 questions (Appendix I) to guide participants memories, and interviews lasted at least one hour. The goal of these confidential interviews was to collect information about how the landscape and built environment of the area has looked and changed over the last 70 to 80 years, and to collect memories of these residents about people, events, and other items of interest, especially any information they may have related to the first Fort Vancouver.

Ethnographic interviews

I conducted confidential ethnographic interviews with current residents of the project area, each interview lasting about one hour. Interview questions were semistructured and focused on particular topics that allowed for open-ended answers from participants (Schensul and LeCompte 2013:140). I used a list of 36 questions (Appendix J) on topics pertaining to personal information, thoughts and views on heritage and archaeology, feelings about place attachment, and any information concerning area history and the first Fort Vancouver. After excavation, I conducted follow-up interviews (Appendix K) with each participant which lasted about 30 minutes to assess whether participation in this project affected how they felt about heritage, archaeology, and the place where they live.

\section{Ethnographic data analysis}

Because I collected ethnographic data with two different methods, surveys and interviews, I used two main strategies for analysis. For the surveys, I entered data by hand into an Excel spreadsheet. I then statistically analyzed the quantitative data by hand, creating percentages for the answers to each question. For the qualitative questions, I 
grouped comments into categories that reflected my research objectives and listed comments related to those categories in a Microsoft Word document. On the first survey (May 2018), I did not specify that the questionnaire continued on the back of the page, so nine of the 31 participants did not answer half of the questions. I resolved this issue on the second survey by stating at the bottom of the page to continue the survey on the back of the paper, and all of the respondents filled out the front and back of the survey.

For the interviews, I entered quantitative data consisting of personal information into an Excel spreadsheet. Most of the interview questions collected qualitative data. I read through participants' answers and identified information with particular characteristics, then sorted characteristics into categories based on my research objectives (LeCompte and Schensul 2010:162). Follow-up interviews were treated the same way. I analyzed data to answer the guiding questions of the study, namely to investigate whether participants' attitudes toward archaeology, heritage, and place attachment had been affected by participation in this project.

\section{Research return}

In its Code of Ethics, the American Anthropological Association (2012) states that anthropologists must be open and honest about their work and make results accessible to others. I strongly believe that public archaeologists should include affected stakeholders in projects and that the research should be returned to communities.

Following anthropological methods, I returned results of my research to participants and the community in two main ways. I delivered a copy of the recorded interviews and transcriptions to interview participants, and field notes and excavation photos to 
excavation participants on flash drives. Secondly, I held several public presentations to introduce my project to the community and to share project results with the community at the end of the project. The presentations were free and open to neighborhood residents and also to people from the City of Vancouver and surrounding areas. These meetings provided the opportunity for the community to learn about the project and to ask questions and comment on issues related to the project.

\section{Archaeological Field Methods}

I used subsurface archaeological survey (shovel test probes) as the excavation method for this project. Washington State does not require a permit for archaeological survey on private property which contains no previously known archaeological sites (RCW 27.53.060). Ideally, a random sample of properties over the entire project area would have been chosen for excavation, but since this was impossible, I used a nonstandard sampling technique by surveying only properties where the homeowners invited me to excavate on their property. Each excavation participant received and signed an informed consent form (Appendix L). Shovel test probe (STP) locations at each property were limited by existing structures and features (such as houses and gardens) and by willingness of residents to allow disturbances in certain areas of their properties. One to three STPs were excavated at each property. Maps of STP locations at each property are presented to my thesis committee only. STPs measured $40 \mathrm{~cm}$ (approximately17 in.) in diameter, and I excavated in natural and arbitrary $10 \mathrm{~cm}$ (approximately 4 in.) levels until I reached at least two sterile levels or encountered a barrier, like a large tree root. As this 
was a public archaeology project, I invited homeowners to work with me during excavation, or to at least watch and ask questions.

Matrix was excavated using a shovel, a flat-pointed masonry trowel, and an archaeological pick, and was screened through nested 1/4- and 1/8-inch mesh hardware cloth. Artifacts were collected, bagged, documented by STP and level, and photographed. Because collection of archaeological artifacts is illegal without a permit from the Washington Department of Archaeology and Historic Preservation (RCW 27.53) all items were returned to the appropriate STP before backfilling. Unit and level information, including sediment descriptions and all relevant information, were recorded digitally on an iPad, and I was prepared to document any features such as post molds, privies, hearths, etc. Profiles of unit walls were photographed with an iPad when possible, although the dimensions of the STPs made this impossible in many cases. Stratigraphic layers were noted on field forms. Field work and artifact documentation were conducted by me under the supervision of Douglas C. Wilson, Ph.D.

\section{Inadvertent discovery plans}

In 1935, during residential construction in the vicinity of project area Section 5 , historic-period human burials were uncovered (Thomas and Freidenburg 1998). Therefore, there was a chance that burials could be discovered during the course of excavation. In the event that human remains and/or funerary objects were found I planned to cease excavation, cover the area, and notify the appropriate consulting parties, including the Washington Department of Archaeology and Historic Preservation (DAHP), the sheriff's office, and the appropriate Tribes, as per Washington State laws 
RCW 68.50 Human Remains, RCW 68.60 Abandoned and Historic Cemeteries and Historic Graves, and RCW 27.44 Indian Graves and Records (Washington DAHP 2019). Artifact analysis

Because I was required to rebury the artifacts discovered during survey, I took photographs in the field and used these images for analysis. I compared the artifacts to items with known dates and origins in the Fort Vancouver collections facility, and through artifact research in documents and books at Fort Vancouver and online. I analyzed artifacts according to standards laid out in the Fort Vancouver Lab Manual (Wilson et al. 2011). Analysis was meant to determine whether the artifacts matched items that would have been in use during occupation of the first fort, or if they were related to an archaeological site of another time period. I recorded data in a computer database. Appendix M includes a Functional Typology I developed for this project and a description of diagnostic artifact types found during project excavations.

As part of this project, I acquired skills in field and laboratory identification of historical artifacts over four years at Fort Vancouver NHS. This prepared me with the knowledge and skills to identify and analyze artifacts from the first Fort Vancouver, as well as artifacts from other time periods found in the project area. From 2015 through 2018, I worked at Fort Vancouver as a graduate research assistant, archaeological laboratory supervisor, and field school teaching assistant.

At the Fort Vancouver lab, I taught laboratory methods, artifact identification, and artifact analysis to university field school students during the summers of 2015, 2016, and 2017; I supervised archaeological volunteers for 20 hours a week during the 2016- 
2017 academic year in correct artifact cleaning methods, artifact identification, and artifact analysis, and properly prepared artifact collections for curation in the Fort Vancouver archive facility; and during the 2017-2018 academic year, I aided in archaeology lab supervision. During my four years of work at the Fort Vancouver archaeological lab, I honed my artifact identification skills, and demonstrated my ability to follow the lab manual (Wilson et al. 2011) and my understanding of material culture categories, as I dealt with artifacts from at least a dozen collections, some of which I worked with from excavation to final curation. I excavated and supervised excavations on numerous $1 \times 1,2 \times 2$, and $1 \times 4$ excavation blocks and trenches during field schools and contract archaeology work, and dealt with artifact assemblages from excavation, to analysis, to curation that represented a range of time periods commonly found at Fort Vancouver: precontact deposits, the HBC Cooper's shop, the HBC stable, HBC's "Ryan's house," the World War I spruce mill, and US Army barracks structures and features. Experience excavating and analyzing artifacts from Fort Vancouver was crucial to the in-field and photographic analysis for this thesis project.

\section{GIS Mapping}

Maps of the project area were created using Google Earth Pro and ArcGIS 10.7.1 showing the locations of the shovel test probes. To protect the privacy of participants, the maps are presented to my thesis committee only. Also included on the maps are locations related to the first Fort Vancouver that current and former residents referred to in interviews, as well as areas of interest gleaned from the documentary record. 


\section{Data Integration}

The four complementary methods of documentary research, public outreach, ethnographic research, and archaeological fieldwork combined to help achieve the three objectives guiding my research. Documentary research laid the foundations for the entire project and combined with public archaeology methods in the archaeological search for the first Fort Vancouver. Documentary background research informed my approach to the ethnographic research, leading to insights into whether participation in an archaeological project leads to change in how residents feel about archaeology, heritage, and place attachment. Public outreach through social media, newspaper articles, presentations, and school visits created community interest in the project and facilitated interactions between myself and community members. These interactions led to participants volunteering for interviews and excavations, as well as public support for this archaeological research. These integrated methods culminated in a project that I believe reveals insights into how public archaeology may be used to conduct an archaeological project with participation of private property landowners, and in making archaeological research relevant and meaningful to communities affected by this research. 


\section{Chapter 5: Public Outreach and Ethnography Results and Discussion}

In this chapter, I discuss the results of public outreach media and presentations, surveys, and interviews. Use of ethnographic methods to assess a community's interest in archaeological research (Atalay 2012:25) guides archaeological work to be relevant to community members, and the ethnographic portion made crucial contributions to achieving the goals of this project. Public outreach methods advertised the project to the community, helped gain public support, and facilitated recruitment of project participants. Informational interviews provided background information about the project area from the often-overlooked resource of living people in archaeological research. Surveys and ethnographic interviews collected data on how involvement in this project affected the ways community members feel about heritage, archaeology, and place attachment. Through public outreach efforts and ethnographic research, I found that local community members and the wider public crave information about area history and archaeology, and that being involved in this project heightened participants' interest in and curiosity about heritage and archaeological research.

\section{Public Outreach Results and Discussion}

Public outreach for this project touched hundreds of people through newspaper articles, project presentations, and social media. These methods introduced and generated support for the project, provided avenues for recruiting interview and excavation participants, and made results of archaeological research accessible to a community of non-archaeologists. Public outreach methods constituted a fulfilling and enjoyable aspect 
of this project, and I agree with Janet Pape (2007:391) that "[p]ublic outreach is the highest reward in archaeology."

Newspaper articles

Newspaper articles provided an effective and practical way to share archaeological research with community stakeholders, and aided in recruiting interview and excavation participants. In April 2018, I was interviewed and photographed by The Columbian newspaper in Vancouver, and a story about my project appeared in print and online on May 2, 2018 (Vogt 2018). Upon completion of the archaeological portion of the project, The Columbian published two more articles on March 26, 2019 (Mize 2019a) and March 27, 2019 (Mize 2019b), and at least one out-of-state news publication (Mize 2019c) picked up the story. The May 2018 article prompted five residents to contact me for participation in the project, and the May 2018 and March 2019 articles attracted audience members for subsequent public presentations.

\section{Presentations}

On May 23, 2018, at the beginning of the project, I held a public presentation at the Fort Vancouver Visitor Center, drawing a crowd of 42 community members to this initial presentation. After watching the presentation, three residents contacted me with interest in participating in the project. Upon completion of excavations and data analysis, I held another presentation at the Fort Vancouver Visitor Center on March 27, 2019. This presentation drew a standing-room-only crowd and many people were turned away at the door. I agreed to hold a second presentation that same night directly after the first, as well as two more presentations on May 11, 2019. Additionally, upon request, I gave 
presentations on my project results and area history at a number of community groups and university classrooms in Vancouver and Portland during the spring and summer of 2019. To date, I have presented programs on archaeology and my project to approximately 650 students, community members, and professionals, inspiring community support, attracting participants to the project, and enlightening community members concerning area history and local archaeology.

In addition to public presentation, I developed a program to introduce archaeology to students at Harney Elementary School to increase awareness and support of and my project in the Edgewood Park neighborhood, with the intention of expanding the number of willing excavation participants. My outreach efforts to Harney Elementary over the 2017-2018 and 2018-2019 school years garnered a response from only one teacher, resulting in only one class presentation at that school. However, through word-of-mouth, teachers at three elementary schools in Portland heard about my program and invited me to present to their classes, for a total of 174 students in seven classrooms in the Portland/Vancouver area.

Reasons for difficulty in getting responses from Harney Elementary School teachers remain unclear. A 2018 poll of the American public found that $87 \%$ of Americans think students should learn about archaeology at some point during their academic career (Society for American Archaeology 2018), and this school's proximity to Fort Vancouver NHS led me to assume teachers here would have a heightened interest in exposing students to archaeology and history. Perhaps teachers dislike responding to unsolicited emails from outsiders, and I would have been more successful with an 
introduction from the parent of a student, or a recommendation from a teacher familiar with me. In general, building trust and familiarity in a community takes time, and in retrospect, making personal connections with school staff earlier in the project would likely have resulted in a greater number of teachers inviting me to present to Harney Elementary classes, perhaps increasing the number of neighborhood families willing to participate in my project

Despite the challenges with engaging with teachers at Harney Elementary, school presentations bolstered my work by sparking interest in and providing publicity for my project. Additionally, the presentations demonstrated to teachers that archaeology is an enjoyable way to learn about the past and it provides an ideal vehicle through which critical thinking skills develop (Little 2007c:145; Bartoy 2012:557). Jeppson and Brauer (2003:83) comment that school-aged children comprise "a vast reservoir of potential stewards" making engagement with this audience critical to the future of archaeology. During these presentations, children made connections between their lives and the lives of those in the past by learning about archaeology and through the exploration of archaeological artifacts (Moe 2002:177). My presentations inspired at least some of the teachers to incorporate archaeology into teaching plans throughout the year (personal communication with teachers from the French American School and Cottonwood School 2018). I found during presentations with school kids that archaeology is the element that makes history come alive. Artifacts provide a tangible connection to past people that history books cannot, taking history from the abstract to the concrete and relatable 
(McGuill 2010:478). Artifacts represent real people and their lives, and archaeology in the classroom can inspire kids in a unique and lasting way.

\section{Social media}

My blog, "Searching for the First Fort Vancouver" at FirstFortVancouver.com, served as medium for sharing project news, posts on archaeology, and project area history (Clearman 2017a). It provided an egalitarian foundation for archaeologists and non-archaeologists alike to learn about and experience public archaeology through posts explaining the methods and practice of archaeology as well as information about my project. Because I designed blog posts to be interesting and relatable to people from varying backgrounds (National Park Service 2014:9), the blog facilitated intellectual and emotional connections (Derry 2003b:19) between blog readers and blog topics. The number of views and its reach beyond the project area reflects the success of the blog: as of this writing blog views number more than 8,000 , and I received several emails from interested readers, even from as far away as eastern Canada. Teachers from the Cottonwood School and the French American School in Portland, Oregon used my blog as a teaching tool in their classrooms, and comments from fellow archaeologists indicate that they show the blog to family members to explain what the practice of archaeology entails.

\section{Survey Results and Discussion}

Anonymous surveys administered at two public presentations gauged how the wider public views heritage and archaeology, and whether or not knowledge of this public archaeology project affected people's attitudes toward heritage and archaeology. 
Thirty-one audience members completed surveys (with nine incomplete) at the presentation at the beginning of the project, and 30 audience members filled out surveys at the presentation at the end of the project. Analysis of both quantitative and qualitative data collected through the surveys shows trends, which I discuss below in four sections: demographic data, thoughts on heritage, feelings about archaeology, and changes in feelings toward heritage and archaeology. For complete survey results, see Appendix N for Survey 1 and Appendix O for Survey 2.

\section{Demographic data}

Quantitative questions collected demographic data on survey participants regarding age and area of residence. Figure 5.1 demonstrates that the age of participants was skewed toward older age: $67.7 \%$ of Survey 1 respondents and $79 \%$ of Survey 2 respondents were age 50 and older, much higher percentages than Vancouver's population which is about $15 \%$ age 65 and older (US Census Bureau 2018). Figure 5.2 shows that most respondents live locally, in Vancouver, and a few said they live in the project area. All but one survey participant said they had visited Fort Vancouver NHS before, and most (87\% in the Survey 1 and $79 \%$ in Survey 2) said they had heard of the first Fort Vancouver before the presentations (Figure 5.3). What these data show is that audience members at these public presentations were mostly older, local, already interested in area history, and had previously sought out information on both the first and second Fort Vancouvers. 


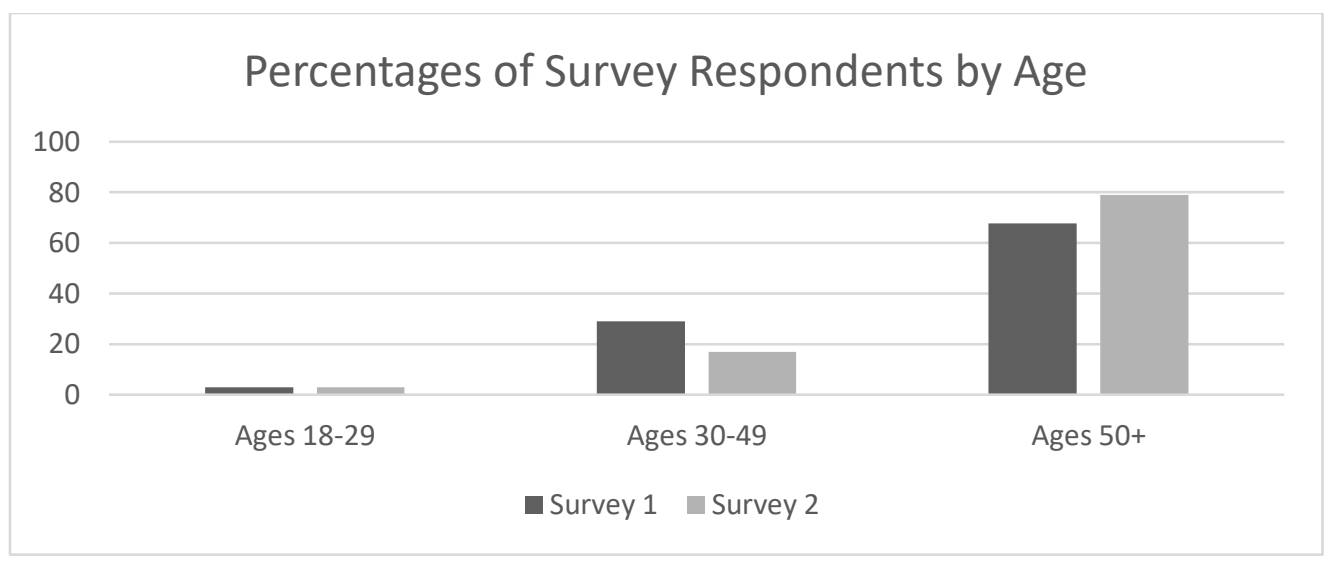

Figure 5.1 Percentages of survey respondents by age

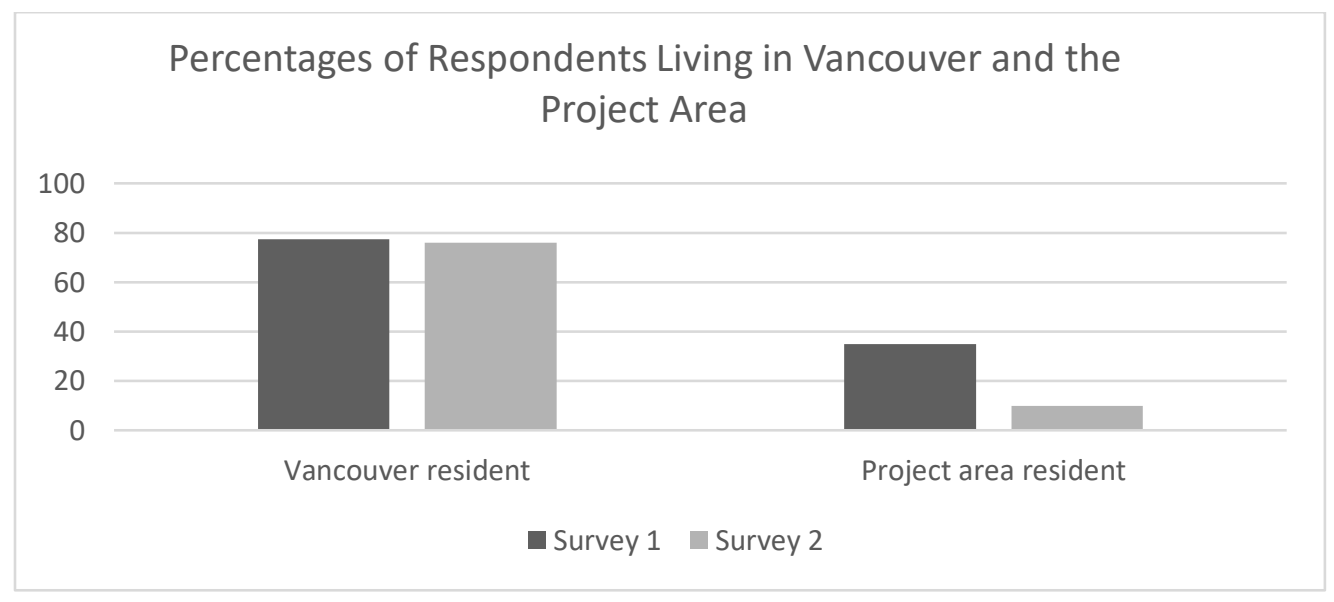

Figure 5.2 Percentages of survey respondents living in Vancouver and the project area

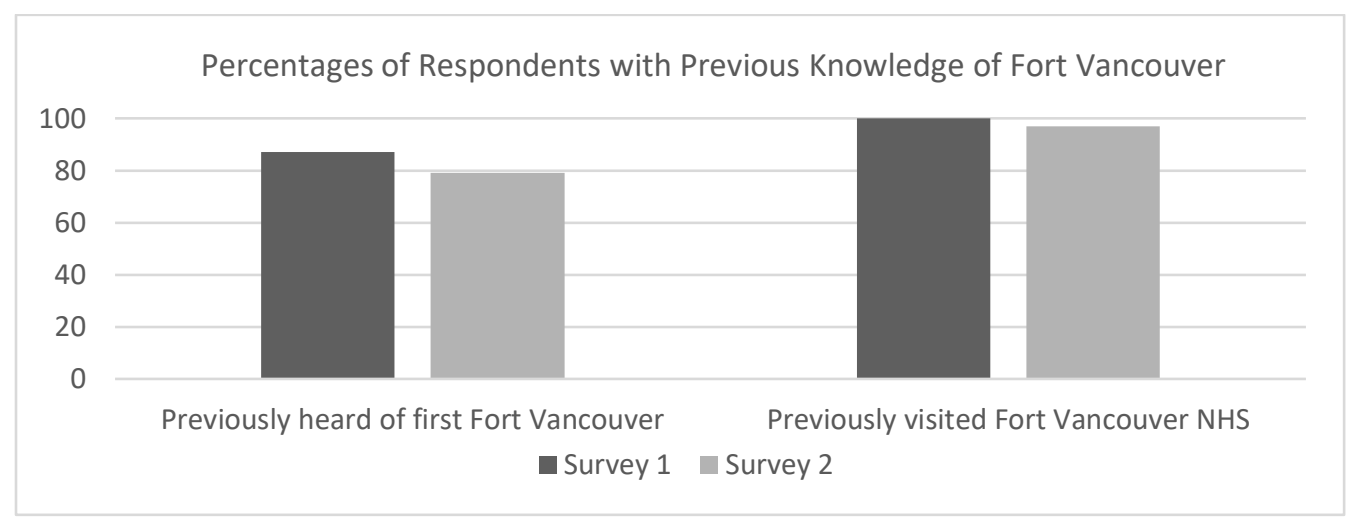

Figure 5.3 Percentages of survey respondents with previous knowledge of the first and second Fort Vancouvers 


\section{Thoughts on heritage}

Qualitative questions collected data on the public's view of heritage. Issues of heritage directly tie to archaeological research, and heritage is associated with a society's values and identity (Jameson and Baugher 2008:7), conjuring ideas of integrity, authenticity, and stability (Shackel 2004:3). This makes an understanding of how community stakeholders view heritage, and how people emotionally connect and identify with heritage, critical for archaeologists interested in increasing the relevancy of their work to communities.

Views of what heritage means to respondents remained virtually unchanged from Survey 1 to Survey 2 (Table 5.1), and the six most common response categories reveal that respondents view heritage as largely personal and tied to identity. While a few saw heritage as something that can reach into the future, the majority regarded it as strictly of the past.

Table 5.1 Survey response categories: What comes to mind when you think of heritage? List 3 words or phrases.

\begin{tabular}{|l|c|l|c|}
\hline $\begin{array}{c}\text { Survey 1 } \\
\text { Top response categories }\end{array}$ & $\begin{array}{c}\text { Number of } \\
\text { responses }\end{array}$ & $\begin{array}{c}\text { Survey 2 } \\
\text { Top response categories }\end{array}$ & $\begin{array}{c}\text { Number of } \\
\text { responses }\end{array}$ \\
\hline History & 17 & History & 18 \\
\hline Culture & 15 & Culture & 16 \\
\hline Ancestry & 13 & Ancestry & 13 \\
\hline Time (past/future) & 13 & Time (past/future) & 8 \\
\hline Personal connection & 12 & Personal connection & 7 \\
\hline Knowledge/Information & 10 & Knowledge/information & 5 \\
\hline
\end{tabular}

People view heritage as important in their communities with more than $90 \%$ responding yes in both surveys (Table 5.2). Table 5.3 lists the top reasons why community heritage is important to participants. In Survey 1, the three most common 
responses referred to knowledge/understanding, history, and personal connections, followed by community/local connections, past/future, and place/landscape. In Survey 2, heritage as a means of informing the present was at the top of the list, followed by history and then knowledge. Community/local connections remained fourth on the list, and community pride/appreciation was added to the responses. These data illustrate that participants feel that the importance of community heritage goes beyond adding knowledge about area history to acting as a facilitator in creating and maintaining connections between people and places across time.

Table 5.2 Survey responses: Is heritage important in your community?

\begin{tabular}{|l|l|}
\hline Survey 1 & Yes $90.3 \%$ \\
\hline Survey 2 & Yes $97 \%$ \\
\hline
\end{tabular}

Table 5.3 Survey response categories: In what ways is heritage important in your community?

\begin{tabular}{|l|c|l|c|}
\hline $\begin{array}{c}\text { Survey 1 } \\
\text { Top response categories }\end{array}$ & $\begin{array}{c}\text { Number of } \\
\text { responses }\end{array}$ & $\begin{array}{c}\text { Survey 2 } \\
\text { Top response categories }\end{array}$ & $\begin{array}{c}\text { Number of } \\
\text { responses }\end{array}$ \\
\hline Knowledge/understanding & 15 & Informs the present/future & 13 \\
\hline History & 13 & History & 9 \\
\hline Personal connections & 11 & Knowledge & 8 \\
\hline $\begin{array}{l}\text { Community/local } \\
\text { connections }\end{array}$ & 8 & $\begin{array}{l}\text { Community/local } \\
\text { connections }\end{array}$ & 8 \\
\hline Reflects time (past/future) & 7 & $\begin{array}{l}\text { Community } \\
\text { pridelappreciation } \\
\text { Connections across time }\end{array}$ & 7 \\
\hline Place/landscape & 6 &
\end{tabular}

Feelings about archaeology

I intended survey questions regarding archaeology to gather a snapshot of where, how, and why non-archaeologists learn about archaeology. This type of understanding helps archaeologists better engage with interested parties (Atalay 2012:1) and gives 
insights into ways archaeologists can reach people who may not know how to access information about archaeology. In 2018, the Society for American Archaeology (SAA) commissioned the company Ipsos to survey the American public regarding thoughts and feelings about archaeology (SAA 2018). The poll mirrors results from my project in finding that most Americans say that the work of archaeologists is important at national and local levels, and that many Americans experience archaeology in a variety of ways.

To find out how respondents already experienced archaeology, in Survey 1, I asked if respondents had previously visited an archaeological site. A surprisingly large number, 55\%, said yes, they had. I asked participants to list ways that they have learned about archaeology, and the most common response was television, followed by visiting a dig, books, magazines, and websites. Survey data suggest that people attending my presentations already possessed some knowledge about and interest in archaeology. Many of them previously visited a dig site and have found numerous ways of learning about archaeology.

Data listed in Tables 5.5, 5.6, 5.7, and 5.8 indicate respondents do value archaeology, especially for what archaeological research can tell us about the past, and they feel the knowledge gained through archaeology is important to themselves personally and to society. Many feel archaeology's significance lies in its ability to facilitate connections between people in the present with events and people in the past, while some simply enjoy it because it interests them. 
Table 5.4 Survey response categories: What comes to mind when you think of archaeology? List 3 words or phrases.

\begin{tabular}{|l|c|l|c|}
\hline $\begin{array}{c}\text { Survey 1 } \\
\text { Top response categories }\end{array}$ & $\begin{array}{c}\text { Number of } \\
\text { responses }\end{array}$ & $\begin{array}{c}\text { Survey 2 } \\
\text { Top response categories }\end{array}$ & $\begin{array}{c}\text { Number of } \\
\text { responses }\end{array}$ \\
\hline History & 19 & Artifacts & 12 \\
\hline Excavation/digging & 13 & Tells the story of the past & 12 \\
\hline People/culture & 10 & People/culture & 10 \\
\hline Research/study & 7 & History & 9 \\
\hline Artifacts & 7 & Excavation/digging & 5 \\
\hline Knowledge & 3 & Research/study & 5 \\
\hline
\end{tabular}

Table 5.5 Survey responses: Is archaeology important to you personally?

\begin{tabular}{|l|l|l|l|}
\hline Survey 1 & Yes $71 \%$ & No $0 \%$ & No response 29\% \\
\hline Survey 2 & Yes $69 \%$ & No 3\% & No response 28\% \\
\hline
\end{tabular}

Table 5.6 Survey response categories: In what ways is archaeology important to your life personally?

\begin{tabular}{|c|c|c|c|}
\hline $\begin{array}{c}\text { Survey } 1 \\
\text { Response categories }\end{array}$ & $\begin{array}{c}\text { Number } \\
\text { of } \\
\text { responses }\end{array}$ & $\begin{array}{c}\text { Survey } 2 \\
\text { Response categories }\end{array}$ & $\begin{array}{c}\text { Number of } \\
\text { responses }\end{array}$ \\
\hline $\begin{array}{l}\text { Increases knowledge of } \\
\text { history }\end{array}$ & 12 & $\begin{array}{l}\text { Increases knowledge of } \\
\text { history }\end{array}$ & 11 \\
\hline $\begin{array}{l}\text { Provides personal } \\
\text { connection and perspective }\end{array}$ & 6 & It is interesting & 8 \\
\hline $\begin{array}{l}\text { Understanding the past to } \\
\text { inform the present }\end{array}$ & 4 & $\begin{array}{l}\text { Facilitates personal } \\
\text { connections with the past }\end{array}$ & 7 \\
\hline It is interesting & 3 & It is educational & 5 \\
\hline Preservation & 2 & It verifies history & 1 \\
\hline
\end{tabular}

Table 5.7 Survey responses: Is archaeology important to society?

\begin{tabular}{|l|l|l|l|}
\hline Survey 1 & Yes $67.7 \%$ & No $0 \%$ & No response $32.3 \%$ \\
\hline Survey 2 & Yes $76 \%$ & No $0 \%$ & No response $24 \%$ \\
\hline
\end{tabular}


Table 5.8 Survey response categories: In what ways is archaeology important to society?

\begin{tabular}{|l|c|l|c|}
\hline \multicolumn{1}{|c|}{$\begin{array}{c}\text { Survey 1 } \\
\text { Response categories }\end{array}$} & $\begin{array}{c}\text { Number of } \\
\text { responses }\end{array}$ & \multicolumn{1}{|c|}{$\begin{array}{c}\text { Survey 2 } \\
\text { Response categories }\end{array}$} & $\begin{array}{c}\text { Number of } \\
\text { responses }\end{array}$ \\
\hline Increases knowledge of the past & 9 & Increases knowledge of the past & 18 \\
\hline $\begin{array}{l}\text { Reveals connections between } \\
\text { past and present }\end{array}$ & 5 & Tells the story of the past & 3 \\
\hline $\begin{array}{l}\text { Understanding the past to } \\
\text { inform the present }\end{array}$ & 4 & Helps preserve the past & 2 \\
\hline Informs the future & 2 & $\begin{array}{l}\text { Helps us communicate about } \\
\text { the past }\end{array}$ & 1 \\
\hline Science & 1 & & \\
\hline
\end{tabular}

Changes in feelings toward heritage and archaeology

By conducting surveys at the beginning and end of the project, I aimed to discover if knowledge of this project changed how people feel about heritage and archaeology. In general, survey data did not indicate much change in feelings, as shown in the above tables and discussion. In Survey 2, I asked if knowledge of this project affected how people feel about heritage and archaeology. $45 \%$ said no, this project did not change how they feel about heritage and archaeology, mainly because they already felt strongly about the value of heritage and archaeology: "I already knew it was important to make the connection" comprised a common response to this question (Appendix O). 14\% of respondents said this project did change their feelings. However, their feelings were not changed, per se; instead this project helped strengthen their interest in heritage and archaeology, especially at the local level (Appendix O).

Although I had intended to use the surveys to gauge changes in feelings of the wider public, results were ambiguous and surveys were insufficient to assess if my project actually caused anyone to feel differently. The addition of surveys failed to add much usable data to this study, likely because survey data was not necessary to address 
the core questions of this project. In hindsight, it would have been better to exclude surveys from this project. To future researchers conducting similar research, I recommend the addition of surveys for larger projects, such as doctoral research, or for smaller studies, such as master's theses, to formulate a project around a large-scale survey while excluding other parts that I used in my project.

I did find that, because demographic data collected in the surveys indicated that audience members were a relatively homogenous group (of older age, local, and already interested in this type of research), there were possibly barriers preventing a more diverse (younger, and newer consumers of history and archaeological research) set of audience members from attending these presentations. From these data, I suggest archaeologists should look for multiple creative ways to reach out to a variety of people and communities to share research with more diverse audiences

\section{Interviews}

In total, I conducted 12 interviews, four informational and eight ethnographic. First, informational interviews with one current and three former residents who lived in the project area beginning in the 1940s, served essentially as life history interviews (Yow 2005:3-4) specifically geared toward participants' childhood memories of their experiences in the project area. Oral historians lament the problem of collected oral histories lying in disuse, from which information might add to scholarship of any number of disciplines (Hamilton and Shopes 2008:vii); below, I demonstrate the rich contribution oral histories can make to archaeological research. Second, I used ethnographic interviews to delve into how participants currently living in the project area make 
meaning from lived experiences (Hollowell and Mortensen 2009:3) specifically regarding heritage, archaeology, and place attachment. I collected data from ethnographic interview participants before and after excavations on their properties. To ensure confidentiality, I do not identify the interview participants in the discussion below, and simply present interview quotes in quotation marks or italics as appropriate.

\section{Informational Interview Results and Discussion}

Two main goals influenced the questions I asked during the four informational interviews. First, as strictly a data collection technique (Hamilton and Shopes 2008:viii), I hoped long-time residents might share information related to area history and the first Fort Vancouver as an aid in locating the first fort and in analysis of artifacts from various time periods. As children in the 1940s and 1950s, these residents potentially heard stories from parents and grandparents about historical people and events in the project area or stories related the first fort. They might also remember finding artifacts that could lead to the location of the fort or give information about other pieces of area history that may be largely unknown. As holders of knowledge not necessarily contained in the documentary record, these residents constitute a non-renewable resource of information that becomes lost when they are gone, severing a crucial connection between past and present (Hamilton and Shopes 2008:viii). Second, I asked questions about how these residents feel about neighborhood change over time to aid in interpretation of attitudes toward heritage and feelings of place attachment in the present. Each interview participant shared unique and personal memories with me, as well as recollections of events and experiences shared by all four, giving clues to cultural values of these participants. Below 
I relate some of the information I learned from the interviews as a demonstration of how knowledge of community members can enrich archaeological interpretation. I analyzed data by reading through the transcripts and identifying key themes pertaining to the project area and goals of my project. I address two main themes: area history divided temporally into subsections - Native Americans, the Hudson's Bay Company, late 19th to 20th centuries - and participants' feelings about the project area and their attachment to it. I include informational interview questions in Appendix I.

\section{Area history}

The project area has been the site of human occupation for centuries. In addition to hosting the first Fort Vancouver, one of the earliest European settlements in the Pacific Northwest (Alley and Munroe-Fraser 1983:26), the area saw occupation by countless generations of American Indians (Deur 2012), the construction of the Kaiser Shipyards

during World War II, and growth from late-19th-century farmland to mid-20th-century residential neighborhoods. The residents I interviewed witnessed historical events in the project area, heard stories from elders about the past, and discovered the material remains left by past occupants of the landscape. Their personal accounts enhance the history chronicled in the documentary record, and, in some cases, reveal new information not included in the written record.

\section{- Native Americans}

While, as Deur (2012:9) notes, the location chosen for Fort Vancouver likely did not host an indigenous village, reports of artifacts suggest a Native presence at the upper prairie on the bluff. Over the past decades, residents claim they and their neighbors found 
Native American artifacts in the project area, such as stone tools, including an obsidian projectile point, and Native-made ceramics. One interview participant remembered his father using a conveyor belt to move earth out from under the house while constructing a basement, and amongst the debris they "found some Native stuff there, some paint pots and some other things." My excavations confirmed and archaeologically documented reports of Native artifacts in the project area through my find of a chert projectile point at one property (see Chapter 6: Archaeological Results and Discussion).

\section{- Hudson's Bay Company}

As I hoped, interview participants did indeed discuss the first Fort Vancouver, and, in fact, I believe this ethnographic information gives evidence that the first fort was located in Section 2 of the project area. Interviewees mentioned early-19th-century artifacts and features discovered at specific locations since the 1940s.

At one property, previous homeowners, expanding their master bedroom, came upon a "pit of blue and white china" with matrix so loose it affected the integrity of the house foundation. An earlier resident of this same property mentioned finding sherds of blue and white ceramics during gardening activities. Still another resident from the property who watched his father using a conveyor belt to move earth out from under the house while constructing a basement, remembers observing "broken pottery like you would find around Fort Vancouver." Additionally, in the vicinity of this property, residents recall picking up fragments of what they describe as early-19th-century artifacts from the dirt streets before the roads became paved, including dark olive vessel glass and ceramics. 
Of particular interest, one interview participant claims a well associated with the first fort was located on the property where he grew up. Apparently, in about 1948 or 1949, this participant's father excavated beneath the home to construct a basement, a common practice during this time period. During excavations, his father encountered a round, gravelly feature. Coincidentally, National Park Service archaeologist Louis Caywood was, at that time, excavating to search for remains of the second Fort Vancouver on the plain near the Columbia River. Caywood agreed to inspect the gravel feature and partially excavate it. The homeowner and Caywood found several artifacts including what Caywood determined was a "Hudson's Bay Company rum bottle" (Figure 5.4), and wooden timbers found in the same area as the gravel feature. Due to the instability of the feature's soil content, Caywood did not fully excavate the feature and the homeowner placed a cement slab over it after Caywood pronounced it to be "definitively the well of the first fort." Documentary research shows that the HBC never dug a successful well on the upper prairie, so this pit is possibly an unsuccessful, filled-in well, or perhaps an HBC pit for some other purpose. The interview participant remembers the rum bottle being on display at Fort Vancouver NHS for several years before its return to the homeowner. In 2018, this participant donated the bottle to the Clark County Historical Museum in Vancouver. 


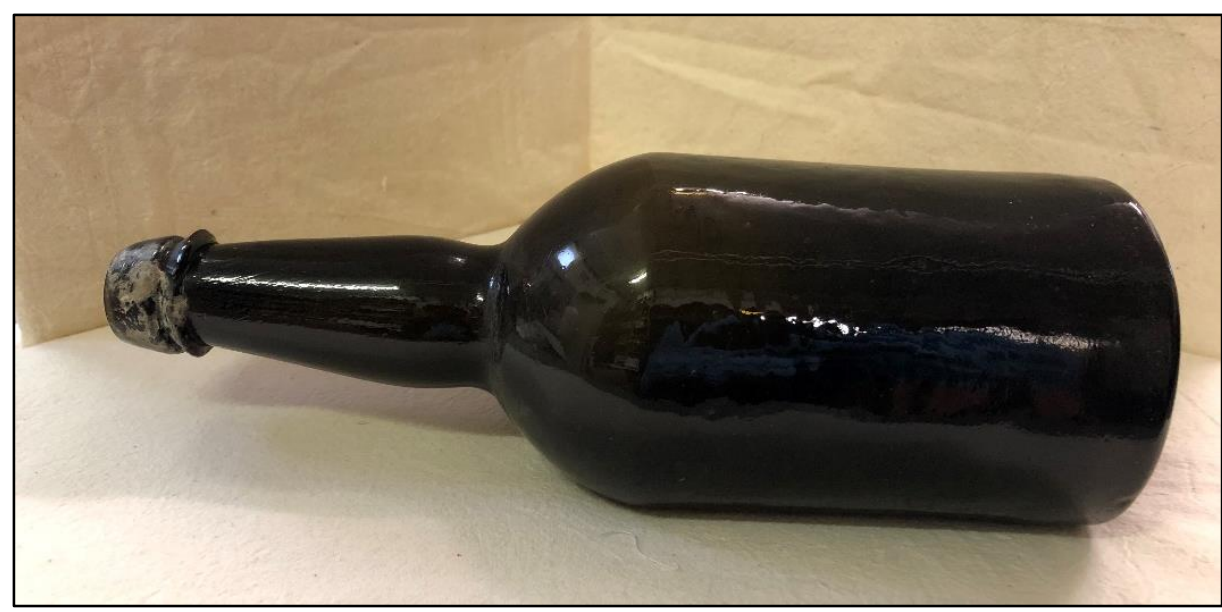

Figure 5.4 Hudson's Bay Company rum bottle discovered in project area Section 2 in the 1940s. Photo courtesy Clark County Historical Museum.

\section{- Late 19th to 20th centuries}

At one time, the project area was farmed, knowledge of which becomes important for artifact identification. This landscape, having likely been cleared of trees and maintained as a camas field by American Indians for many generations prior (Deur 2012), appealed to the influx of American settlers as ideal for crop and pasture land. Residents today admire the remaining old farmhouses still standing as architectural reminders of the once bucolic landscape, and some interviewees even witnessed the time when much of the project area comprised farmland. One interview participant recalled growing up in this area: "When I was small ... everybody had a farm. Everybody had five acres or ten acres or twenty acres, and had cows, and did all of that."

Another resident was born and raised on a 40-acre farm, which included land below and on top of the bluff. Built by her grandparents around 1900, the farm and the family were known to probably every resident in the area. Fred Casper Boss started Boss Farm as a dairy operation on 5th Street in between Blandford Drive and Grand Blvd. Boss 
bought the land from the Durgins, donation land claim holders of the site, around the turn of the 20th century. In the 1950s, Fred Boss' son bought the 40 -acre farm, which included three acres on the bluff, from his mother, and continued the dairy and beef farm business, with part of the property having been sold to Henry Kaiser during WWII, some sold to build Highway 14 and a power station, and the rest sold to the Nath family later.

During WWII, the project area saw the construction of Kaiser's Vancouver Shipyards and associated workers' housing, and an influx of workers from around the United States, some of whom remained in the area, accelerating change in the landscape of the area. One interview participant commented, "it's amazing how many of the people are still in Vancouver that were here in the forties" who moved here to work in the shipyards. Residents note changes made to accommodate the swell of children to the neighborhood because of the shipyard workers. As youngsters, these residents remember Harney Elementary School as quite small, with flimsy buildings added later to receive the sudden influx of students. Harney School has changed over the decades from wood to brick to wood again and remains a source of neighborhood pride; according to one interviewee it is "the oldest continuous grade school site in the state of Washington."

\section{Feelings about the neighborhood and place attachment}

As I discuss in the next section, current residents that I interviewed, especially in the Edgewood Park neighborhood, experience strong place attachment to their neighborhood. This sense of place attachment reaches back decades as seen through stories and information gleaned in the informational interviews with long-time residents. 
These residents speak fondly of life in this neighborhood and of the lifelong relationships which originated here, and their memories reflect current feelings of place attachment.

During ethnographic interviews, discussed below, current residents mentioned that it is the uniqueness of the landscape and of the people that make this area special, thoughts echoed by those who grew up here beginning in the 1940s. Of mid-20th-century life in the Edgewood Park neighborhood, one interview participant noted, "I felt like we had a great neighborhood there. ... [I]t was a fun place." Growing up in the 1940s and 1950s, these residents enjoyed the freedom to wander and explore. Young children were allowed to walk to school alone and no one was worried: "It wouldn't be a walk that you'd allow your five-year-old to make by themselves now. But in those days, everybody walked." With much less home and industrial construction, nature played a large role in the lives of these kids: "What I really remember about that is that there were toads all over the place. You could find these great big frogs under any house. You could go under a house and you could catch, I mean, they were good sized. And garter snakes. All over the place." Ponds located on the plain just below the bluff constituted a chief destination for area youth, and their frequent mentions in interviews revealed area residents' fondness for these ponds. Some stories told by interviewees center on a large pond, now virtually obliterated by imported fill and industrial buildings, located on the Boss farm just south of 5th Street. Residents recall playing near the pond as children, ice skating on it in the winter, and fishing there for carp and catfish. Introduced from the southern United States for purchase by Vancouver's Victorian-era consumers (Taber 2018), carp and catfish in this pond were likely stocked during the late 1800s. While these fish were 
"societally reviled" during the Victorian era (Taber 2018: 132), youngsters in the mid20th century enjoyed catching these bottom-feeding fish.

\section{Ethnographic Interview Results and Discussion}

Surveys, discussed earlier in this chapter, asked community members about their thoughts and feelings on heritage and archaeology, however, these types of surveys make it difficult to find out why people respond the way they do (McClanahan 2006:127). To dive deeper into feelings regarding heritage, archaeology, and place attachment, I conducted confidential ethnographic interviews with residents from eight project area households. Initial interviews with these residents collected demographic and personal information; thoughts on heritage, archaeology, and place attachment; and information about project area history. I returned on a different day to excavate at these properties, then returned a third time to conduct follow-up interviews to find out how being directly involved in an archaeological project on private property affected how these residents feel about heritage, archaeology, and place attachment. I include lists of questions from ethnographic and follow-up interviews in Appendices L and M. The following discussion includes illustrative quotes from interviews. Instead of selecting one or two representative quotes for each topic, I chose to include a number of quotes, each of which expresses unique thoughts particularly relevant to conclusions drawn from interviews.

\section{Demographic and personal data}

Interview participants numbered 12 people from eight households, interviewed as individuals and couples. Five participants were female and seven were male. Ages ranged from 31 to 67 years old, with an average age of 51. Length of time living in the current 
home ranges from two years to 32 years, with an average of six years in the current home. All own their homes, built from the 1930s to 1960s and the early 2000s. Four participants are retired, while the rest work professionally in fields such as education, science, commercial management, sales, and design.

\section{Thoughts on heritage}

In the interviews, I wanted to find out how people view heritage in their lives and communities, and if being directly involved in an archaeological project in their neighborhood, specifically on private property, affects how they view heritage. Because archaeological research directly ties to history and heritage (Jameson and Baugher 2008:7) and heritage represents what individuals and societies feel is important to preserve and to pass on to future generations (Shackel 2004:10), data on how people view heritage becomes beneficial to archaeologists in the quest to make archaeology more relevant to the communities the research affects. "[H]eritage connotes cultural inheritance" (Jameson and Baugher 2008:7), and from interview questions on how participants view heritage, two main themes related to cultural inheritance emerged. First, these residents clearly feel that cultural connections - to people, places, ancestry, knowledge - make heritage relevant:

I feel a pretty strong connection to my heritage past and where I come from because my family actually came here on the Oregon Trail. I think that kind of connection to a place is what makes me feel strong about my heritage.

$[F]$ amily and community and history. Kind of where you come from is kind of what I think of heritage.

[H]eritage means the kind of things you're connected with, connected to. ... The history of this area. 
I would have to say a connection to your past. ... Where I come from, where my family, when they came over to this country, the politics, the world that they came into, it's all part of the heritage of growing up, good, bad, or ugly, it's all part you.

I guess thinking about it there's that connection to the history of the heritage of feeling individually connected somehow or through your parents or your family history or the neighborhood history. ... I think also of wanting to continue it on in the future, either for ourselves to continue on, thinking about or learning more about one aspect, or passing it on into future generations.

Second, these residents see beyond heritage as simply a way of knowing about history to viewing it as something that directly informs their personal identity through cultural inheritance:

[Heritage is] historical people or events that give you a sense of identity or somehow influence your life in the present.

[F]or me it's important because I have such long history in this place. So, I feel super rooted here, and so I think that's a big part of who I am in way, is having a connection to this place.

It's very important to me. I think it partially defines who we are, who we can be, or who we become.

It's sort of part of how I define myself and identify myself and how my children identify themselves.

Heritage, to these residents, appears to center on them as individuals; the answers above mainly focused on their own personal roots and identities. However, since they clearly view heritage in the light of interconnectedness and identity, I wanted to know how they view community heritage, specifically the heritage of their neighborhood, to find out how these residents might relate to a heritage based on place shared by people across time. Their answers demonstrated that visible heritage, things evident on the landscape, is crucial for fostering feelings of connectedness to people who lived here in 
the past. As one resident noted, "being visually reminded of the history and the heritage is a good thing" because the parts of area heritage that are not readily visible, for which only stories are known are "a little hard to think about versus something that you see tangible in front of you. So, you know the Kaiser thing was more recent [and currently more visible] versus the Native American times. That's a little harder to connect with." Evidence of the Kaiser shipyards was a common response to ways people see heritage in their neighborhood because some shipyard workers' homes still remain. For these residents, visible heritage of the built environment, the natural environment in the form of large, mature trees, and the human element of generational longevity arose as themes of how they see neighborhood heritage:

I would say the huge trees makes you realize this neighborhood has been around for a long time [and] I definitely feel like you can see the houses as they have aged in time, but a lot of them have a lot of unique architecture and style.

I think the most obvious evidence of any kind of heritage in this neighborhood is the influence of World War II and the Kaiser Shipyards ... this area was really support for all those ventures, the shipyards and the fort primarily and then other industry. And then all the way down through here there were paper mills. It was a heavily industrial area. This supported the work for those as well.

[T]here is the sign over by the School for the Deaf, so that kind of reminds me that there's more than meets the eye. Or that there are layers of history or heritage.

The generational aspects that you were talking about of people staying in the neighborhood. There's a lot of people who have stayed in the neighborhood. I would say that's the heritage.

The multi-layers of heritage and history in this neighborhood, it's all here, if you know where to look.

Heritage is definitely a neighborhood asset, according to these residents, and has the potential to inspire community pride, community action, and a sense of belonging: 
It's a huge asset. I think it's what makes the neighborhood desirable.

I think there's a pretty strong sense of community here, and with that comes this curiosity about this place. If you feel connected with the people here, it causes this connection to the place too.

I think it's a matter of getting that story out there a little bit more. And making it make sense in terms of this century. ... Because once people take interest in their heritage there's nothing you can do to stop them. ... [U]nderstanding history and heritage would be a great way to bring people together and would give them a sense of belonging and owning.

These residents seem to realize that this place has a unique story and a significant past, and expressed wanting to learn more about neighborhood history, perhaps through presentations on neighborhood history. Some also stated interest in having a book written about the area: "ideally ... a written history of the neighborhood, of what is known. I think that'd be a great resource for people moving into the neighborhood."

Finally, I wondered if direct involvement in an archaeological investigation on their own property would have any affect at all on how these residents view heritage. During the follow-up interviews, I asked if participants feel any differently about neighborhood heritage after the project. In short, residents answered not really, because they already felt strongly about it, although, just as I found in the surveys, involvement in the project deepened their appreciation for and curiosity about neighborhood history:

I guess personally I see that there are possibilities that the neighborhood has a deeper history than what I might have imagined. This helped put flesh and bones and structure to what those ideas might have been.

It's all a lot more interesting. I mean we've always been a little bit interested. But it's a deeper interest now.

[I]t's given us a more richer picture of the neighborhood. Because I've always tied it to post-World War II. But there is a bunch of mystery as to what was here, 1820 to 1860. That's been really fun to see. 
[N]ow being in the neighborhood and near potentially areas or very close to where all these things were occurring [first Fort Vancouver], and the things you were mentioning of the Native Americans using it for the camas field [at the May, 2018 presentation], there is kind of that connection now that kind of just dawned on me right at this moment.

\section{Feelings about archaeology}

I intended ethnographic interviews to gain insight into how project area residents feel about archaeology, and if direct involvement in archaeological research, specifically on private property, changed these residents' feelings regarding archaeology. First, to get an idea of how interview participants experienced archaeology before the project, I asked what the word archaeology means to these residents. Just as Plumer (2018) found, participants in my project seem often to conjure images of excavations:

Finding old stuff. ... The digs and all that kind of stuff.

I think of you guys collecting things, you find things... you're just going in the dirt.

However, I also found that many of these residents understood that the ultimate aim of archaeology is to figure out the story of the past:

[I] tmeans to me finding parts of history through excavation and research. And using those pieces, the artifacts to determine what history was like.

Digging stuff out of the ground. Studying it, learning about it. Putting a picture together of what used to be there.

Archaeology means evidence of ... somebody here before me.

[D]iscovering, finding, preserving what you can of the past, and sharing that information. ... [F]or me it's proving things, or disproving things that we've heard our whole lives. 
It's kind of a dusty scene in my mind ... trying to piece together finding objects and things and not knowing necessarily right off what they are but trying to piece together what potentially is this, what was it used for, what would it tell us about the people that were using that thing.

To find out how these residents felt about archaeology before the project, I asked if they thought archaeology affects their lives. Some with no previous direct interaction with archaeology, said they find it interesting, but that it did not necessarily affect them personally:

Not directly, maybe, but I guess things that get discovered inform history for all of us and create understanding.

I would say not in a direct sense, but it certainly enriches everybody. To know where we came from and how we got here and civilizations that have come and gone. I find that particularly interesting. ... It makes a richer life. But I don't know that on a day to day basis it has that much of an impact.

Some felt a personal connection because of direct experience with artifact collecting or first-hand knowledge of archaeological projects:

I've learned about it, read about it. Because I found [artifacts] for one, that affected me personally.

[T]hrough projects such as yours.

Others felt like archaeology affects their lives because they find it interesting and through strong connections to the neighborhood:

It is to me, because I've always had an interest in it.

Well, it's important to me. I don't know about anybody else, but it's important to me. ... But I think I care about the area and have a different ideal of the neighborhood than most people would probably.

It enriches it. It makes it worth being alive, I'm that excited about it. 
When asked if archaeology is important in their neighborhood, residents generally

feel that it is, in part because of the unique history of the project area:

In our neighborhood, well, clearly it is! It's kind of exciting to think that something kind of significant was here before these houses.

[I]f you dig down and find the fort was over here and then there was a richer story to this area, that would be fascinating and a fun thing to incorporate into our lives.

I think for this neighborhood, related to your project, before we knew about you, [we heard] stories, it made the neighborhood more exciting.

For others, archaeology's importance stems from its ability to reveal commonalities amongst people:

[Archaeology reveals that] we all come from the same area, we're all part of it. If you live here thirty, forty years you become part of it, whether you want to or not.

[I]t's the one thing that we all have in common. And that is something that, no matter what your lifestyle or what you subscribe to or whatever, it doesn't matter because we do have this one simple thing. And that's what I enjoy. It's a common ground that everybody has and can respect.

And for society, the importance comes from the questions about the past archaeology is seen to be able to answer:

I guess as a whole I think it's important to know what happened in our history.

I do think it's important to see where we came from, how we've evolved, moved on.

I think it's vital to our story. I think that's what we're here for ... remembering our ancestors, why is that important. Remembering who they were, this is the way we honor them, through archaeology because we end up finding out who they really were, what they used every day as an example, or once in a while. It enriches it ... I think it's vital to the world. ... And I think by bringing it home here to Hudson's Bay makes it less abstract. 
To investigate even further what these residents think about archaeology, I asked how they would feel if an archaeological site was found on their property:

I would be excited! That would be super awesome, I think. I think because of my history I'm a total history nerd about stuff around here.

I would love it. I would want to be digging out there with you.

Even those with some fear of potential restrictions to their property rights expressed excitement at finding a site on their property:

I would probably have mixed emotions, but mostly excited. I would probably be doing a lot of bragging. A lot of bragging. I imagine it creates other little issues, but it would probably be worth it.

Absolutely excited. I know it would mean some limitations about what we could do with that site, but that's fine. I think if it served in some of the roles that I mentioned and that you believe in, that would serve a purpose. That's really what we're here to do.

Bad, if I was trying to remodel. But, no, I hope you can find some things.

[I]t would depend on the impact. But it would be interesting.

I think I would feel pretty excited about that. I'd want to tell a lot of people. ... There's almost a bit of a fear, of what does that mean ... but I think it would be neat, to be able to brag ... having that even more connection with that heritage, more immediate things.

Some archaeologists worry that involving resident stakeholders in archaeology might adversely affect either the people or the archaeological resources: Does involvement in archaeological research make people bored and lose interest (Plumer 2018:65)? Or does it increase the risk that these residents will loot and plunder the sites we want them to protect (Richardson and Almansa-Sánchez 2015:204)? I found instead that involvement made the participants in this project more interested and curious about 
archaeology, especially in their neighborhood. At follow-up interviews I asked, after being involved in this project, do you feel differently about archaeology?

[I'm] more interested in it, it's kind of more on the map for me. So, when it comes up in the news and things, I'm a little more tuned in to that and connect that to the experience with your work.

Involvement also seemed to increase these participants' appreciation of the process of archaeological research after seeing the level of detail and scientific rigor with which I excavated. Witnessing the details of the work removes archaeology from the abstract and the mysterious and makes it tangible and relatable:

I thought it was very interesting in terms of the deep technical detail in terms of the stratifications that you identified as you dug the hole, even on our complete fill.

I realize that it's worse than fishing. You can go on forever and not find anything. It's a very slow process and it's not like you're going to just take a spoonful of dirt out of the ground and find something. No, it was interesting to see how you did the test holes, the size, everything about it, you just see how little ground-it really is a crap shoot if you're going to find something. It doesn't mean there isn't stuff all around you, you just happen to hit a spot where there's just nothing. It's just a game of patience, you just have to wait, and keep trekking there and see if you find something.

And finally, involvement made them more concerned with preservation of archaeological resources:

I'm looking across the street and they're digging there and thinking maybe it's erasing evidence of previous people who have been there. So maybe just thinking a little bit more about what was there before and if we're erasing things and if that's okay or not. So maybe I've just thought a little bit more about the consequences of making landscape changes and things like that.

I asked if these residents feel any differently about archaeology's importance in their neighborhood and society. Again, being involved in the project did not appear to 
change anyone's minds, but involvement did seem to make some participants feel even more strongly about archaeology's importance:

I think it's astonishingly important in terms of being able to understand what happened in the place where you're living.

[I now have] a deeper and more relatable connection to it.

I wish we could be part of more of that type of thing.

\section{Place attachment}

Place attachment, "the bonding of people to places" (Low and Altman 1992:2), formed a cornerstone concept in this study. People living on land on and near archaeological sites are resident stakeholders in archaeology (Wright 2015), and therefore hold a vested interest in specific sites of cultural heritage. The connections these resident stakeholders feel to the land where they live matters to archaeologists because, by choice or default, they are the stewards of the cultural resources held in the landscape they occupy. Schaepe et al. (2017:502) observe that archaeology can foster an interconnectedness “among people, places, objects, knowledges, ancestries, ecosystems, and worldviews," and the connections between people and places make people want to protect and preserve what is held in places of personal importance.

While feelings of attachment to the project area neighborhoods cropped up throughout the interviews, I intended three questions to elicit responses specifically about place attachment. First, I asked, what areas are most important to you in your neighborhood and what makes your neighborhood special? Three main themes arose from this question: people, history, and the built and natural environments: 
[I] thas some history with the Kaiser Shipyard. ... So that kind of makes it special to me. And this area has really mature trees, and I really like that and I like to walk there. And I think it's the people that actually make the neighborhood ... what I like is that they have lived here for a long time and so they have that sense of community.

As far as our modern history in the sense that as Europeans came out here, this neighborhood is at the core of it ... standing here on the bluff you would have seen Lewis and Clark drift by ... this whole place - Vancouver was known for prune orchards. We used to have a festival much larger than Portland's Rose Festival. And they had a Miss Prune. ... The Kaiser family built the home here right in this neighborhood to overlook the building of the ships down below. ... General Harney, this actually sits on his homestead that he took out. ... So everything that happened as far as what really was taking place in the Pacific Northwest really started right here, and a lot of it right in this neighborhood.

For me it's the fact that people still walk. People walk their dogs constantly. Everybody's walking everywhere. People are generally friendlier it seems like. It's just kind of a gem. The trees are - I love trees. Trees are super important to me. The fact that you have old established trees.

We have a lot of amazing friends in the neighborhood. We all are friends. And it's generational. There's just so much community, you know?

Second, I asked if these residents feel attached to their neighborhood, and I found that most feel very attached to the neighborhood:

$Y a, I$ do, and I didn't really expect that. I think it's really just the sense of community and how it just has a really quaint feel to it. Ya, I definitely feel a sense of attachment. Coming from Portland I was not expecting to love Vancouver.

I am guilty of that. I am very, very attached to that neighborhood.

Ya, this is a wonderful neighborhood. ... [W] hen I moved up here and I started learning about this neighborhood, it became fascinating to me. [Discovering an ancestral connection to Fort Vancouver] was something I'd looked for my whole life, was kind of having something that you had some sort of a connection to. And when I came here all of the sudden it was like wow. Whoa, I knew this.

Ya, definitely. Here we feel that, and again, due to the people, and the welcoming, and seeing the people, and feeling a part of the neighborhood. 
Yes, definitely ... we just can't stand the thought of not living in the neighborhood.

And, third, I asked how these residents feel about having Fort Vancouver NHS so near their homes:

It's pretty special I feel like. It's pretty awesome to have something right next to you, something that significant.

I love it. It's like a blessing to have that resource and the history. The reality is we actually spend quite a bit of time down there.

I think it's a great privilege to be close to a location like that that's wellpreserved and well taken care of and the public has access to it and you can walk through it. ... It's just part of daily life. That part is very interesting to me. And I appreciate that.

Ya, I think it's great. I love walking there. And when we have guests from out of town we go walking there to the reconstructed fort. I just like the open space. I always like how they have different events there, the Park Service putting on different events. It's all very multi-use, I think a lot of people enjoy the space without thinking anything about the heritage ... it adds value to the community.

I think it's been invaluable and it's only brought positive aspects to the whole thing, the region, the neighborhood. We have a national park because of it. Who can say that? Who can say that they can ride down the street to a national park in the middle of the city?

In follow-up interviews I asked whether these residents feel any changes in how attached they feel to the neighborhood after being involved in my project. Again, just as with heritage and archaeology, residents did not feel much change except to feel more of a connection to the neighborhood and more interest in the history of the area:

I think I feel more attached to the importance of history now. That history happens where you are, not down somewhere else. And that idea has been something that's been coming up with me, and you've helped me to realize that. As I look around and realize there's so much more to this. That's what's changed for me.

No, I've always been aware of this. It's nice to know that more people now have come out and said a few things ... that's opened up some dialog between people 
and getting more in touch with homes that haven't, maybe it's not associated with the first fort, but just this neighborhood in itself.

I think we've grown more involved and more attached ... in this last year. And part of it is this connection to the history. So, we appreciate that.

\section{Ethnographic Discussion}

Ethnography used in archaeological research does more than supplement archaeological research; archaeological ethnography seeks to make archaeological research relevant and to understand how it becomes meaningful to all affected stakeholders. As archaeologists become increasingly accountable to the communities their research affects, ethnography is more and more important for understanding the effects of archaeological research on community attitudes about place, heritage, identity (Hollowell and Mortensen 2009:5), and archaeology. Carman (2006:95) observes, often as archaeologists "we do not know what we do does" [emphasis added] for affected stakeholders, and ethnographic studies like mine can help gauge how archaeological work impacts stakeholders, making our work more meaningful and relevant. After involvement in this research, I found that residents feel increased positivity toward and heightened personal relevance concerning heritage and archaeology, and deeper feelings of place attachment and area pride. I selected three observations that I feel particularly address the essential question of my research; namely, does involvement in a public archaeology project affect how participants feel about heritage, archaeology, and place attachment?

1. Involvement brings people and heritage/archaeology closer together 
Any time an archaeologist embarks on a project, they enter a situation where people already experience the past in a multitude of ways (Hollowell and Mortensen 2009:2). Archaeologists do not bring history and archaeology to people; the places that archaeologists work come ready-made with a past, and the people that archaeologists interact with possess their own ideas, perceptions, and experiences, potentially both positive and negative, concerning history and archaeology. However, archaeological ethnographies can bring heritage and archaeology closer to people and people closer to heritage and archaeology (McGuill 2010:469), and can provide space to explore "the implications of archaeological practice" (Hollowell and Mortensen 2009:1) for the individual and community stakeholders in archaeology.

All the residents I worked with had thoughts about, feelings for, and experiences with heritage and archaeology long before I showed up at their homes. Being directly involved in an archaeological project, especially one in their neighborhood and on their own property, amplified the interest level of these residents in the practice and methods of archaeology, and heightened their appreciation for the knowledge gained through this research. One resident said, "I appreciate more the challenges that clearly are part of trying to figure out what the heck happened in certain areas." Residents now feel a deeper understanding of the process and of how archaeological research affects them and society: "[I realized even more] how valuable it is ... archaeology links us to so many things about ourselves. I think it's vital.” Heritage feels deeply personal, helping form their identities, and weaving archaeology with personal and community heritage (Edgeworth 2006:xiii) via connections between people, places, ancestry, and knowledge 
about the past (Rosenzweig and Thelen 1998). In this area where Fort Vancouver NHS makes an archaeological site a prominent feature of the landscape, and where residents already had thoughts on, feelings for, and experiences with heritage and archaeology, I did not bring heritage and archaeology to the community; my project simply brought people, heritage, and archaeology closer together.

2. Available materials affect how people view heritage, archaeology, and place

During this project I found that the materials available to these neighborhood residents affect how they view heritage, archaeology, and the project area: "Everyone concerned with the past ... constructs ideas and images of the past from materials available in the present" (Gazin-Schwartz and Holtorf 1999:3). Prior to this project, these residents' curiosity about the heritage of their neighborhood centered on things they could see on the landscape - Fort Vancouver NHS, Kaiser shipyard homes, historic trees - and knowledge available to them in books and other reading materials. As detailed in the constructivist model (Bartoy 2012:554), involvement in this project provided additional materials from which residents construct ideas and images of the past, extending the 'heritagescape' (Garden 2010) to include what lies below the ground. Several participants mentioned that after participating in this project, they now look around at the landscape with a changed point of view: "I'm definitely a lot more curious. ... I just look at places and think, hmm, I wonder what's in their yard. ... It's really interesting to be part of an experience around archaeology. It just makes you think about it in a little bit of a different way. Just more connected to it." These residents scaffolded knowledge (Bartoy 2012:555) gained through this project on things they already knew to 
create a new way of seeing heritage and area history and are now more curious about area history and the stories that lay buried beneath the ground.

\section{Involvement in archaeological projects deepens feelings of place attachment}

Not only are landscapes altered by the people who occupy them, places become embedded in people's identities through place attachment (Gifford 2014:543; Wright 2015:214). Identity formation through place attachment plays a critical role in how people experience heritage and archaeology, and because emotional connections and social bonding constitute key components of place attachment, personal engagement in archaeological projects can help people in the present identify with and connect with people who lived in the past (Uunila 2003:39). A project like mine on private property in a residential neighborhood becomes a powerful vehicle for fostering feelings of closeness and familiarity with people in past, and involvement in this project enhanced participants' feelings toward heritage and archaeology and of connectedness to people across time based on place. Connections felt with people in the past became evident in residents' comments:

[This project] makes me think a little more carefully about, even if the location of the fort wasn't there, for sure humans were using that area and passing through it. So, it helps me think a little bit more about all the layers of people that have been there before us.

Every time we can pause and reflect and say there was somebody here before, I wonder what they were doing, and anytime we can find those records I think is very important to our daily lives.

From a pragmatic standpoint (Mrozowski 2012), place attachment intensified by involvement in an archaeological project leads to feelings of the increased relevancy of heritage and archaeology. As I found with participants, when place attachment makes 
heritage and archaeology more relevant, people often feel more motivated to protect and preserve the cultural resources found there. This makes efforts by archaeologists and preservationists to understand the connections between people and places essential for improving preservation efforts involving archaeological sites on private property and the value placed on cultural resources (McGuill 2010:478).

Additionally, these residents realized more of a connection with the people they share this landscape with in the present; one participant articulated, "history is one those things in this country, even though people might have different interpretation of what happened, your project brings up the fact that there is a common heritage here." A common heritage based on place can bring a sense of well-being to a community (Jameson and Baugher 2008:7), and participants seem to feel that, as reflected in this participant's comment: "a sense of place is vital to the health of the neighborhood." Participants expressed excitement about sharing details of this project with each other and with other residents who had not directly participated, and told me that it brought people together around a shared interest. Awareness of this enthusiasm prompted one resident to state:

I think that makes me feel like there's this kind of communal interest in the history or the heritage of the neighborhood that I didn't know that people felt that strongly about before. So that makes me feel like the people are great and that makes the neighborhood great. But then also that people are invested in the neighborhood itself and proud of the neighborhood too. And seeking meaning in the neighborhood. So that strengthens the ties that bind us together.

\section{Concluding Remarks}

Ultimately, I am asking with this research, what role do heritage and archaeology play in people's everyday lives, and what role do they have the potential to play? The only way to answer questions like these is by talking to living people, in this case resident 
stakeholders living in an area of rich heritage and archaeology. McGuill (2010:473-4)

believes that "archaeology is not worth doing unless it directly benefits modern populations in some way." I learned in surveys and interviews that people do not necessarily expect heritage and archaeology to solve the major problems of the world; they feel benefits and enrichment simply by learning and knowing about heritage and archaeology. This project seemed to enhance participants' lives by helping them feel more connected to those in the past, and participants expressed feeling more connected to the people who shared this landscape over time. Further, many of them said that by learning about the history and archaeology of the area they feel even more connected to people in the present. In the words of one participant, "it's a common ground that connects us all." 


\section{Chapter 6: Archaeological Results and Discussion}

This chapter presents the results of excavation for each project area section and a discussion of the archaeological findings and artifact analysis.

As discussed in Chapter 2: Background, the documentary record unambiguously describes the location of the first Fort Vancouver on the high land above the Columbia River. Contemporaneous diarists placed the fort on the upper prairie, and maps marked the road to the first fort leading from the Columbia River, in between two lakes on the Jolie Prairie, up the steep bluff to the upper prairie. However, the exact location of the fort is unclear in the documents, making the discovery of the location of the first fort solely using information from the documentary record unlikely. An archaeological search may be the best method for finding material remains of the fort, however, previous archaeological research has never pinpointed the fort's exact location. Archaeological research in the project area is hindered largely because access to the landscape as an urban residential neighborhood is highly limited. This project partially addressed this issue through participation of neighborhood residents on private property.

Working with property owners in this project was a positive experience, although excavating on private property presented certain challenges. First, unlike many archaeological survey projects where an archaeologist has admittance to an entire project area, access to the land for this project was limited. Excavation could only take place at properties where property owners invited me, making it impossible to deploy a random sampling method across the entire project area. Random sampling during archaeological survey is intended to yield statistically significant results by the selection of a certain 
number of testing locations arbitrarily scattered across a project area (Hester et al. 2009:28). To make the sample size as robust as possible, I needed to recruit as many willing participants as I could. I employed a variety of public outreach methods, outlined in Chapter 4: Methods. Recruitment techniques resulted in twelve homeowners allowing excavation out of more than 200 properties across the two neighborhoods. Twelve locations within an area measuring approximately one square mile is sparse sampling. As Wright (2015:217) found during a similar project, I believe difficulty in recruiting participants can be traced to a lack of trust of archaeologists in general. This lack of trust coupled with misunderstandings about the impacts and consequences of the project made recruitment challenging.

Limitations in obtaining an adequate sample was compounded by restrictions on where and how much I could excavate at each property. Structures, such as homes and garages, mature trees, manicured lawns, garden beds, and utility lines contributed in narrowing the number of locations available to place shovel test probes (STPs). Property owners dictated where they would allow excavation, with some guidance from me, so that they remained in control of impacts to their properties. I wanted all participants to feel comfortable with the process and promised homeowners minimal impact and disturbance to the property. This meant excavation could occur only in limited locations. In addition to location restrictions, the number of STPs I could excavate at each property was constrained by time. I aimed for minimal time spent at each property to reduce impacts to homeowners, and because I was working alone, this meant I only had time to excavate between two and four STPs at each property. Limits in time and location 
resulted in excavation of a total of 32 STPs over the twelve properties making this a small sample given the size of the project area.

Private property is generally not available for archaeological study unless a construction project requires archaeological investigation. Because all archaeology previously done in the project area has been limited to CRM for construction-related ventures, my project offered a unique opportunity for archaeological exploration at previously inaccessible locations in the Hudson's Bay and Edgewood Park neighborhoods (Figure 6.1). Although my sample alone is insufficient for adequate testing of the project area, this project built on previous CRM studies and will aid future investigators seeking and studying the first fort. Archaeological testing of the project area remains an iterative process, with each step providing additional clues in the search for the first Fort Vancouver.

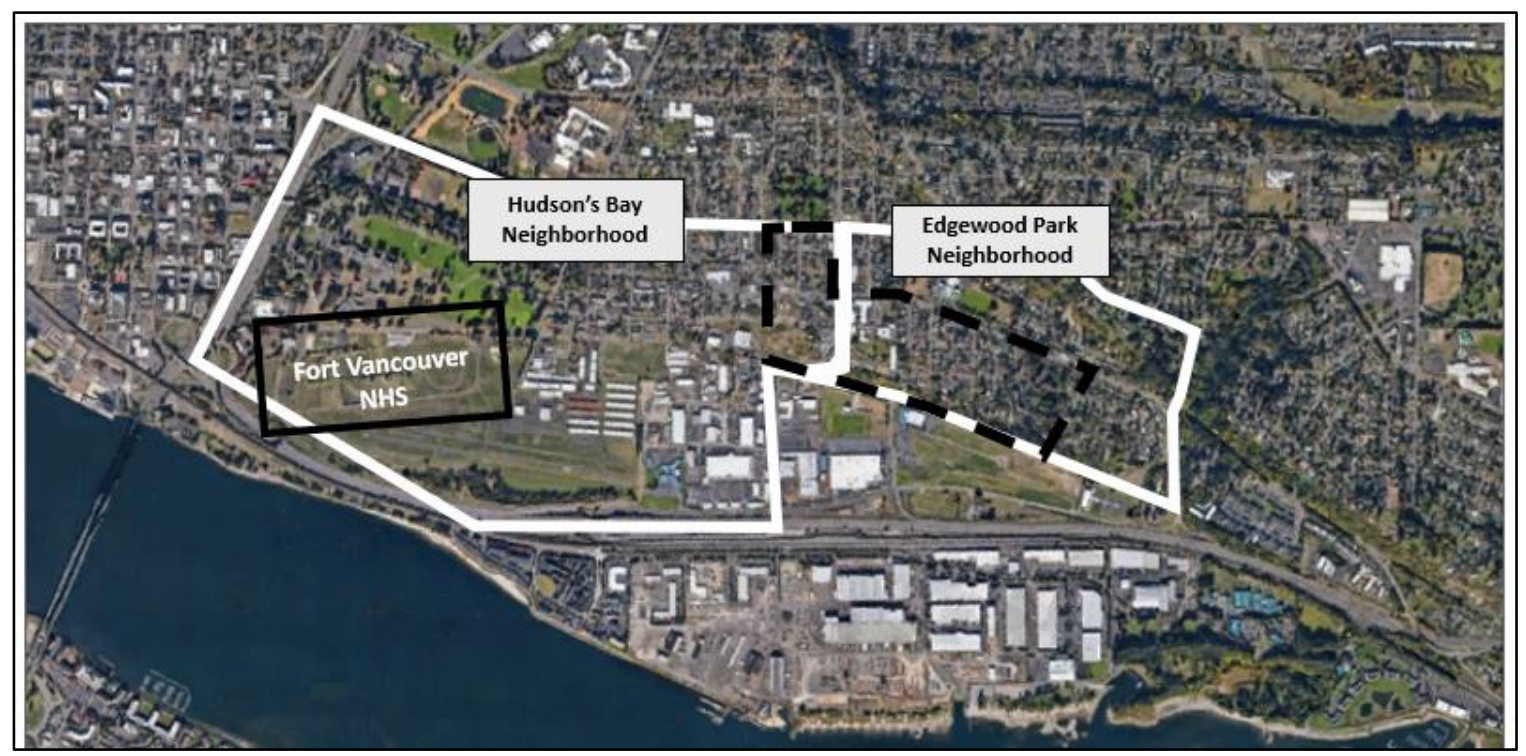

Figure 6.1 Project area neighborhoods, Hudson's Bay and Edgewood Park. Black dashed line surrounds the project area. Basemap from Google Earth Pro with labels added by the author. 


\section{Excavation Results}

Because I promised confidentiality to the participants of this project, I do not reveal names or property addresses in this thesis. I divided the project area into five sections to more clearly demonstrate the ways the archaeology occurs across the landscape (Figure 6.2). I determined the five sections by grouping the excavation properties based on their spatial relationships and potential site-level connections. This level of property identification protects the confidentiality of homeowners and the locations of cultural resources, while showing trends in material remains across the project area.

The tables and figures below describe data and information for each section: number of STPs per excavation property and section (Table 6.2), the volume of matrix excavated per property and section (Table 6.3), artifact counts and densities by time period (Tables 6.4, 6.5, 6.6, 6.7 and Figure 6.3), and a table of the interpretation of artifacts by time period per STP (Table 6.8). Graphically presented data are followed by archaeological results for the project area and for each section with photos of representative artifacts.

Archaeological results from my project are compared with related archaeological investigations in the area to fill out the story of the project area landscape. Archaeological investigations include those conducted by the contract archaeological company Archaeological Services, LLC (ASCC). In addition to a 2018 job in my project area that ASCC invited me to examine, in 2009, ASCC archaeologically monitored the replacement of sewer lines in the streets of a large portion of the Edgewood Park 
neighborhood by the City of Vancouver. Because this area is designated as having a medium to high probability of containing archaeological resources, the sewer work required an archaeologist to monitor the work to identify any archaeological artifacts or features uncovered during mechanical excavations.

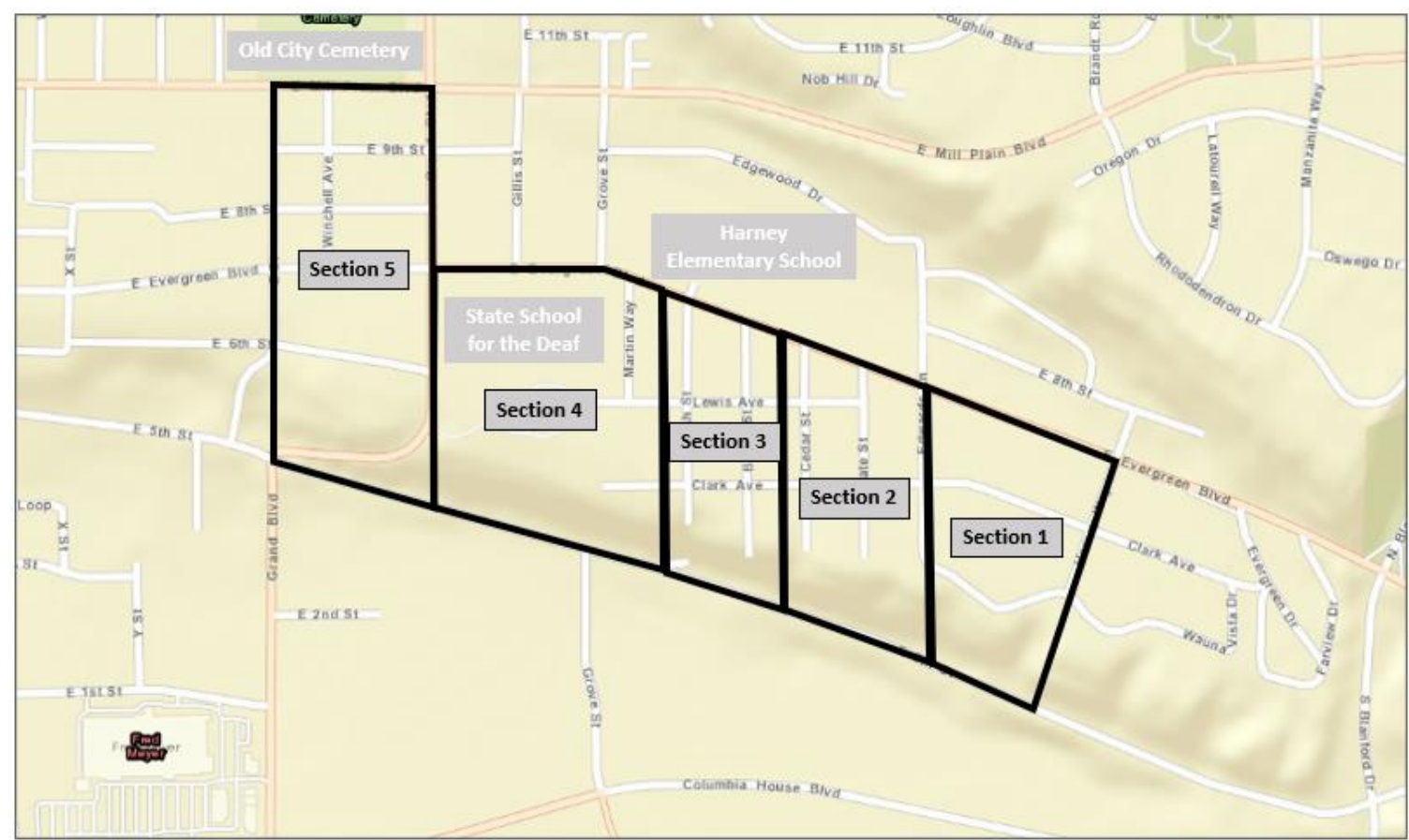

Figure 6.2 Map delineating the five project area sections in black polygons. Basemap from ArcMap 10.7.1 with labels added by the author.

Table 6.1 Section boundaries

\begin{tabular}{|l|l|l|l|l|l|}
\hline & Section 1 & Section 2 & Section 3 & Section 4 & Section 5 \\
\hline North & $\begin{array}{l}\text { E. Evergreen } \\
\text { Blvd }\end{array}$ & $\begin{array}{l}\text { E. Evergreen } \\
\text { Blvd }\end{array}$ & $\begin{array}{l}\text { E. Evergreen } \\
\text { Blvd }\end{array}$ & $\begin{array}{l}\text { E. Evergreen } \\
\text { Blvd }\end{array}$ & $\begin{array}{l}\text { E. Mill Plain } \\
\text { Blvd }\end{array}$ \\
\hline East & Harney Drive & Edwards Lane & $\begin{array}{l}\text { Between } \\
\text { Beech Street } \\
\text { and Cedar } \\
\text { Street }\end{array}$ & $\begin{array}{l}\text { Between } \\
\text { Martin Way } \\
\text { and Ash Street }\end{array}$ & Grand Blvd \\
\hline West & Edwards Lane & $\begin{array}{l}\text { Between } \\
\text { Beech Street } \\
\text { and Cedar } \\
\text { Street }\end{array}$ & $\begin{array}{l}\text { Between } \\
\text { Martin Way } \\
\text { and Ash Street }\end{array}$ & Grand Blvd & Z Street \\
\hline South & E. $5^{\text {th } \text { Street }}$ & E. $5^{\text {th } \text { Street }}$ & E. $5^{\text {th Street }}$ & E. $5^{\text {th } \text { Street }}$ & E. $5^{\text {th } \text { Street }}$ \\
\hline
\end{tabular}


Table 6.2 Shovel test probes per property per section

\begin{tabular}{|c|c|c|l|}
\hline Section No. & $\begin{array}{c}\text { Excavation Property (EP) } \\
\text { No. }\end{array}$ & $\begin{array}{c}\text { Quantity of shovel test } \\
\text { probes per property }\end{array}$ & $\begin{array}{c}\text { Shovel Test Probes } \\
\text { (STP) numbers }\end{array}$ \\
\hline 1 & 3 & 3 & $5,6,11$ \\
\hline 1 & 5 & 2 & 9,10 \\
\hline 1 & 6 & 2 & 12,15 \\
\hline 1 & 7 & 2 & 13,14 \\
\hline 2 & 2 & 2 & 3,4 \\
\hline 2 & 10 & 3 & $22,23,24$ \\
\hline 2 & 11 & 4 & $27,28,29,30$ \\
\hline 2 & 12 & 2 & 31,32 \\
\hline 3 & 1 & 2 & 1,2 \\
\hline 3 & 9 & 3 & $19,20,21$ \\
\hline 4 & 8 & 4 & $17,18,25,26$ \\
\hline 5 & 4 & 3 & $7,8,16$ \\
\hline
\end{tabular}

Table 6.3 Total volume of matrix excavated per property and per section $\left(\mathrm{m}^{3}\right)$

\begin{tabular}{|c|c|c|c|}
\hline Section & EP & $\begin{array}{c}\text { Volume of matrix } \\
\left(\mathbf{m}^{\mathbf{3}}\right)\end{array}$ & $\begin{array}{c}\text { Totals } \\
\left(\mathbf{m}^{3}\right)\end{array}$ \\
\hline 1 & 3 & 0.177 & \\
\hline 1 & 5 & 0.155 & \\
\hline 1 & 6 & 0.165 & \\
\hline \multirow[t]{2}{*}{1} & 7 & 0.098 & \\
\hline & & Section 1 Total & 0.595 \\
\hline 2 & 2 & 0.170 & \\
\hline 2 & 10 & 0.195 & \\
\hline 2 & 11 & 0.327 & \\
\hline \multirow[t]{2}{*}{2} & 12 & 0.170 & \\
\hline & & Section 2 Total & 0.861 \\
\hline 3 & 1 & 0.192 & \\
\hline \multirow[t]{2}{*}{3} & 9 & 0.192 & \\
\hline & & Section 3 Total & 0.384 \\
\hline \multirow[t]{2}{*}{4} & 8 & 0.253 & \\
\hline & & Section 4 Total & 0.253 \\
\hline \multirow[t]{3}{*}{5} & 4 & 0.216 & \\
\hline & & Section 5 Total & 0.216 \\
\hline & & & $2.309 \mathrm{~m}^{3}$ \\
\hline
\end{tabular}


Table 6.4 Count of 20th-century to present-day artifacts and artifact densities and percentages per section

\begin{tabular}{|c|c|c|c|c|c|c|}
\hline $\begin{array}{l}\text { 20th-century to present-day } \\
\text { artifact type }\end{array}$ & $\begin{array}{c}\text { Section } \\
1\end{array}$ & $\begin{array}{c}\text { Section } \\
2\end{array}$ & $\begin{array}{c}\text { Section } \\
3\end{array}$ & $\begin{array}{c}\text { Section } \\
4\end{array}$ & $\begin{array}{c}\text { Section } \\
5\end{array}$ & Totals \\
\hline Brick, American & 16 & 2 & & & 5 & 18 \\
\hline Bead, plastic & 1 & & & & & 1 \\
\hline Ceramic, flower pot & & & & & 2 & 2 \\
\hline Ceramic, tableware & & & 4 & & 3 & 7 \\
\hline Concrete/asphalt slab & 1 & & 1 & & & 2 \\
\hline Fabric, cloth & & & & & 1 & 1 \\
\hline Fabric, landscaping & & & & & 2 & 2 \\
\hline Foil & 1 & 1 & & & & 2 \\
\hline Glass object & & 3 & & & 2 & 5 \\
\hline $\begin{array}{l}\text { Metal burn barrel } \\
\text { fragments }\end{array}$ & 26 & & & & & 26 \\
\hline Metal fragments & 8 & & & & 1 & 9 \\
\hline Metal object & 5 & 2 & 1 & & 3 & 11 \\
\hline Mortar, concrete & 3 & & & & 9 & 12 \\
\hline Nail, wire & 7 & 8 & 8 & & 12 & 35 \\
\hline Paper & & 1 & & & & 1 \\
\hline Plastics & 1 & 24 & 2 & 1 & 28 & 56 \\
\hline Roof tile, composite & & 3 & 1 & & 1 & 5 \\
\hline $\begin{array}{l}\text { Vessel glass, machine- } \\
\text { made, amber }\end{array}$ & 5 & 4 & 3 & & 4 & 16 \\
\hline $\begin{array}{l}\text { Vessel glass, machine } \\
\text { made, amethyst }\end{array}$ & & & & 5 & & 5 \\
\hline $\begin{array}{l}\text { Vessel glass, machine- } \\
\text { made, aqua }\end{array}$ & & 1 & & & 3 & 4 \\
\hline $\begin{array}{l}\text { Vessel glass, machine- } \\
\text { made, colorless }\end{array}$ & 31 & 13 & 3 & 2 & 19 & 68 \\
\hline $\begin{array}{l}\text { Vessel glass, machine- } \\
\text { made, green }\end{array}$ & & 3 & & & & 3 \\
\hline $\begin{array}{l}\text { Vessel glass, machine- } \\
\text { made, milk glass }\end{array}$ & 1 & & & & 1 & 2 \\
\hline $\begin{array}{l}\text { Vessel glass, machine- } \\
\text { made, olive green }\end{array}$ & 1 & & & & & 1 \\
\hline Wax (crayon) & & 1 & & & & 1 \\
\hline Window glass & 10 & 3 & 3 & 1 & 9 & 26 \\
\hline Wood, worked and painted & 1 & & & & & 1 \\
\hline Totals & 118 & 69 & 26 & 9 & 105 & 327 \\
\hline Artifact densities per $\mathbf{m}^{3}$ & 198.4 & 80.2 & 223.7 & 35.6 & 486.1 & 141.7 \\
\hline Percentage of total artifacts & $25.0 \%$ & $14.6 \%$ & $5.5 \%$ & $1.9 \%$ & $22.2 \%$ & $69.2 \%$ \\
\hline
\end{tabular}


Table 6.5 19th-century artifact counts and artifact densities and percentages per section. Note: none of the artifacts are associated with the early 19th century or the first Fort Vancouver with the possible exception of worked wood (boards) found in Section 2.

\begin{tabular}{|c|c|c|c|c|c|c|}
\hline $\begin{array}{l}\text { 19th-century artifact } \\
\text { types }\end{array}$ & $\begin{array}{c}\text { Section } \\
1\end{array}$ & $\begin{array}{l}\text { Section } \\
2\end{array}$ & $\begin{array}{c}\text { Section } \\
3\end{array}$ & $\begin{array}{c}\text { Section } \\
4\end{array}$ & $\begin{array}{c}\text { Section } \\
5\end{array}$ & Totals \\
\hline $\begin{array}{l}\text { Ceramic, decorated } \\
\text { whiteware }\end{array}$ & 3 & 3 & & & & 6 \\
\hline Ceramic, porcelain & 3 & & & & & 3 \\
\hline Ceramic, Rockinghamware & 1 & & & & & 1 \\
\hline $\begin{array}{l}\text { Ceramic, transferprint, } \\
\text { blue-and-white }\end{array}$ & 1 & & & & & 1 \\
\hline $\begin{array}{l}\text { Ceramic, undecorated } \\
\text { whiteware }\end{array}$ & 19 & & & & & 19 \\
\hline $\begin{array}{l}\text { Machine-cut nails, } \\
\text { American }\end{array}$ & 3 & 2 & & & & 5 \\
\hline $\begin{array}{l}\text { Square-cut nail, } \\
\text { indeterminate }\end{array}$ & 1 & & & & & 1 \\
\hline Metal object & 3 & & & & & 3 \\
\hline $\begin{array}{l}\text { Vessel glass, blown-into- } \\
\text { mold amber }\end{array}$ & 1 & & & & & $\mathbf{1}$ \\
\hline $\begin{array}{l}\text { Vessel glass, blown-into- } \\
\text { mold, aqua }\end{array}$ & 2 & & & & & 2 \\
\hline $\begin{array}{l}\text { Vessel glass, blown-into- } \\
\text { mold, dark olive green }\end{array}$ & 6 & & & & & 6 \\
\hline Wood, worked & & 3 & & & & 3 \\
\hline Totals & 43 & 8 & $\mathbf{0}$ & $\mathbf{0}$ & $\mathbf{0}$ & 51 \\
\hline Artifact densities per $\mathbf{m}^{3}$ & 72.3 & 9.3 & $\mathbf{0}$ & $\mathbf{0}$ & $\mathbf{0}$ & 22.1 \\
\hline Percentage of total artifacts & $9.1 \%$ & $1.7 \%$ & $\mathbf{0}$ & $\mathbf{0}$ & $\mathbf{0}$ & $10.8 \%$ \\
\hline
\end{tabular}

Table 6.6 Precontact artifact counts and artifact densities and percentages per section

\begin{tabular}{|l|c|c|c|c|c|c|}
\hline Precontact artifact types & Section & Section & Section & Section & Section & Totals \\
& $\mathbf{1}$ & $\mathbf{2}$ & $\mathbf{3}$ & $\mathbf{4}$ & $\mathbf{5}$ & \\
\hline Fire cracked rock & & 8 & & 12 & & 20 \\
\hline Projectile point & & 1 & & & & $\mathbf{1}$ \\
\hline Totals & $\mathbf{0}$ & $\mathbf{9}$ & $\mathbf{0}$ & $\mathbf{1 2}$ & $\mathbf{0}$ & $\mathbf{2 1}$ \\
\hline Artifact densities per $\mathbf{m}^{\mathbf{3}}$ & $\mathbf{0}$ & $\mathbf{1 0 . 5}$ & $\mathbf{0}$ & $\mathbf{4 7 . 5}$ & $\mathbf{0}$ & $\mathbf{9 . 1}$ \\
\hline Percentage of total artifacts & $\mathbf{0}$ & $\mathbf{1 . 9 \%}$ & $\mathbf{0}$ & $\mathbf{2 . 5 \%}$ & $\mathbf{0}$ & $\mathbf{4 . 4 \%}$ \\
\hline
\end{tabular}


Table 6.7 Undatable artifact counts and artifact densities and percentages per section

\begin{tabular}{|l|c|c|c|c|c|c|}
\hline Undatable artifact types & $\begin{array}{c}\text { Section } \\
\mathbf{1}\end{array}$ & $\begin{array}{c}\text { Section } \\
\mathbf{2}\end{array}$ & $\begin{array}{c}\text { Section } \\
\mathbf{3}\end{array}$ & $\begin{array}{c}\text { Section } \\
\mathbf{4}\end{array}$ & $\begin{array}{c}\text { Section } \\
\mathbf{5}\end{array}$ & Totals \\
\hline Bead, glass & & & & & 1 & $\mathbf{1}$ \\
\hline Bone, animal & 5 & 9 & 7 & & 6 & $\mathbf{2 7}$ \\
\hline Coal & & & 2 & & 2 & $\mathbf{4}$ \\
\hline Glass, colorless & 4 & & & & & $\mathbf{4}$ \\
\hline Nails, indeterminate & 19 & 10 & & & 3 & $\mathbf{3 2}$ \\
\hline Shell & 2 & & & & 1 & $\mathbf{3}$ \\
\hline Wood, worked & & 1 & & & & 1 \\
\hline Unknown & & & & & 1 & $\mathbf{1}$ \\
\hline Totals & $\mathbf{3 0}$ & $\mathbf{2 0}$ & $\mathbf{9}$ & $\mathbf{0}$ & $\mathbf{1 4}$ & $\mathbf{7 3}$ \\
\hline Artifact densities per $\mathbf{~ m}^{\mathbf{3}}$ & $\mathbf{5 0 . 4}$ & $\mathbf{2 3 . 2}$ & $\mathbf{2 3 . 4}$ & $\mathbf{0}$ & $\mathbf{6 4 . 8}$ & $\mathbf{3 1 . 6}$ \\
\hline Percentage of total artifacts & $\mathbf{6 . 4 \%}$ & $\mathbf{4 . 0 \%}$ & $\mathbf{1 . 9 \%}$ & $\mathbf{0}$ & $\mathbf{3 . 0 \%}$ & $\mathbf{1 5 . 5 \%}$ \\
\hline
\end{tabular}

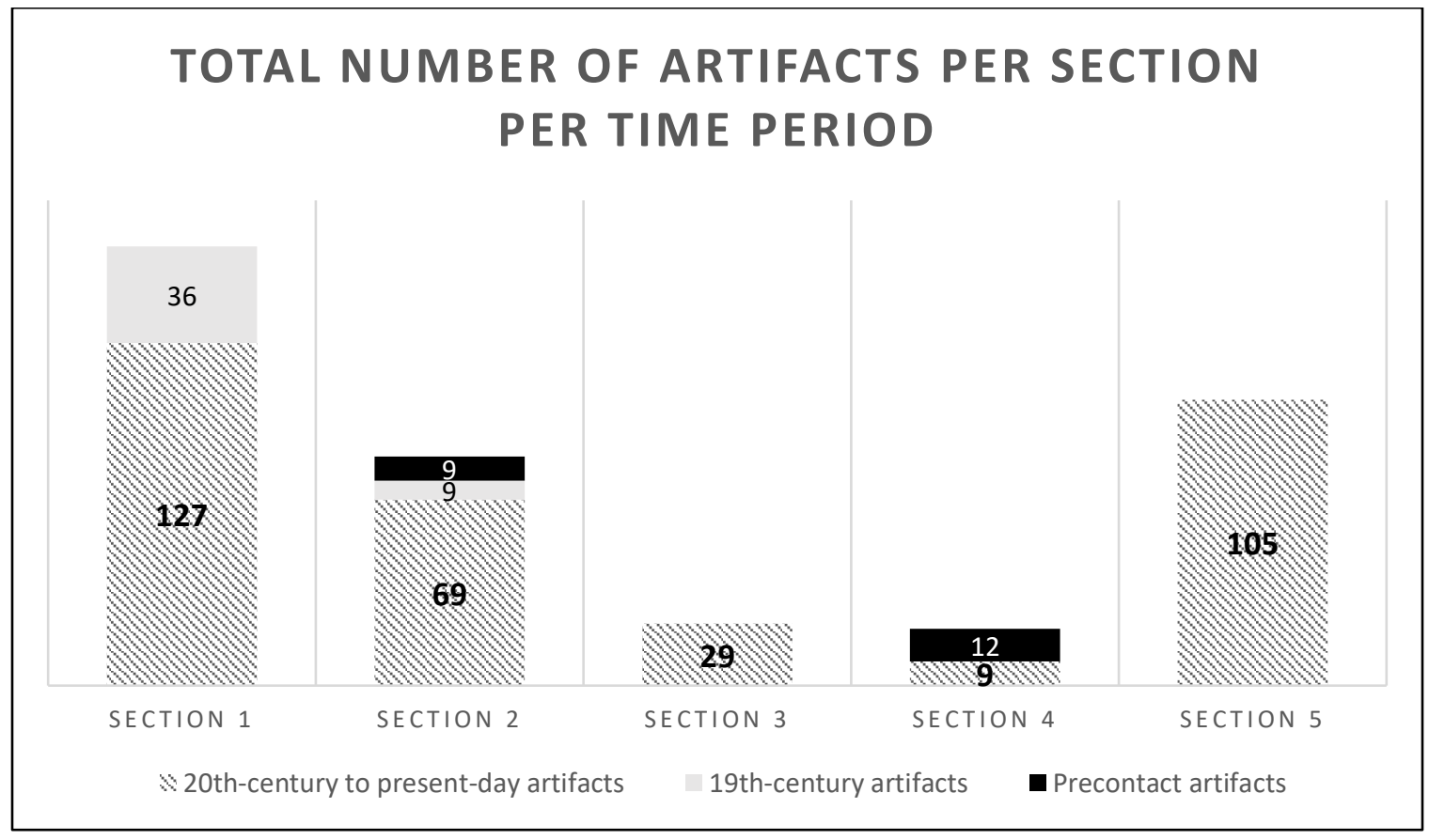

Figure 6.3 Total number of artifacts per time period per section, excluding undatable artifacts 
Table 6.8 Representative artifacts by time period, and interpretation by STP

\begin{tabular}{|c|c|c|c|c|c|c|c|}
\hline Section & Location & $\begin{array}{c}\text { 20th-century to present- } \\
\text { day representative artifact } \\
\text { types }\end{array}$ & $\begin{array}{l}\text { 19th-century } \\
\text { representative } \\
\text { artifact types }\end{array}$ & $\begin{array}{c}\text { Pre-contact } \\
\text { artifact } \\
\text { types }\end{array}$ & $\begin{array}{c}\text { Unknown } \\
\text { time } \\
\text { period }\end{array}$ & Interpretation & $\begin{array}{c}\begin{array}{c}\text { Number } \\
\text { of } \\
\text { artifacts }\end{array} \\
\end{array}$ \\
\hline 1 & $\begin{array}{l}\text { EP } 3 \\
\text { STP } 5\end{array}$ & $\begin{array}{l}\text { Metal fragments (burn } \\
\text { barrel), wire nails, clear } \\
\text { vessel glass, amber vessel } \\
\text { glass, milk glass, plastics }\end{array}$ & & & Charcoal & $\begin{array}{l}\text { Burn barrel debris, } \\
\text { domestic debris, } \\
\text { casual dumping, } \\
\text { loss }\end{array}$ & 48 \\
\hline 1 & $\begin{array}{l}\text { EP 3 } \\
\text { STP } 6\end{array}$ & & & & $\begin{array}{l}\text { Wood } \\
\text { fragments, } \\
\text { charcoal }\end{array}$ & Unknown & 0 \\
\hline 1 & $\begin{array}{l}\text { EP 3 } \\
\text { STP } 11\end{array}$ & Clear vessel glass & & & & $\begin{array}{l}\text { Domestic debris, } \\
\text { loss }\end{array}$ & 1 \\
\hline 1 & $\begin{array}{l}\text { EP } 5 \\
\text { STP } 9\end{array}$ & Wire nails, clear vessel glass & & & Charcoal & $\begin{array}{l}\text { Domestic debris, } \\
\text { loss }\end{array}$ & 7 \\
\hline 1 & $\begin{array}{l}\text { EP 5 } \\
\text { STP } 10\end{array}$ & None & & & & & 0 \\
\hline 1 & $\begin{array}{l}\text { EP } 6 \\
\text { STP } 12\end{array}$ & $\begin{array}{l}\text { Metal sheeting, American } \\
\text { brick, window glass, clear } \\
\text { vessel glass }\end{array}$ & $\begin{array}{l}\text { Decorated whiteware, } \\
\text { undecorated whiteware, } \\
\text { aqua blown-into-mold } \\
\text { vessel glass, olive blown- } \\
\text { into-mold vessel glass, } \\
\text { Rockinghamware, } \\
\text { American machine-cut } \\
\text { nails, metal objects }\end{array}$ & & Charcoal & $\begin{array}{l}20^{\text {th }} \text {-century } \\
\text { construction and } \\
\text { domestic debris, } \\
19^{\text {th }} \text {-century British } \\
\text { Royal Navy } \\
\text { structure called } \\
\text { Dundas' Folly }\end{array}$ & 77 \\
\hline 1 & $\begin{array}{l}\text { EP } 6 \\
\text { STP } 15\end{array}$ & $\begin{array}{l}\text { American brick, window } \\
\text { glass, plastic bead, clear } \\
\text { vessel glass, ceramic flower } \\
\text { pot fragments, olive } \\
\text { machine-made vessel glass }\end{array}$ & $\begin{array}{l}\text { Blue-and-white } \\
\text { transferprint, porcelain }\end{array}$ & & $\begin{array}{l}\text { Animal } \\
\text { bone, } \\
\text { charcoal }\end{array}$ & $\begin{array}{l}\text { Loss and casual } \\
\text { dumping during } \\
20^{\text {th }} \text {-century } \\
\text { construction and } \\
\text { domestic debris, } \\
19^{\text {th }} \text {-century British } \\
\text { Royal Navy } \\
\text { structure called } \\
\text { Dundas' Folly }\end{array}$ & 31 \\
\hline
\end{tabular}




\begin{tabular}{|c|c|c|c|c|c|c|c|}
\hline 1 & $\begin{array}{l}\text { EP 7 } \\
\text { STP } 13\end{array}$ & American brick & & & & Construction debris & 3 \\
\hline 1 & $\begin{array}{l}\text { EP 7 } \\
\text { STP } 14\end{array}$ & $\begin{array}{l}\text { American brick, painted } \\
\text { wood, undecorated } \\
\text { whiteware, amber vessel } \\
\text { glass, clear vessel glass, } \\
\text { concrete, window glass }\end{array}$ & & & $\begin{array}{l}\text { Animal } \\
\text { bone, } \\
\text { charcoal }\end{array}$ & $\begin{array}{l}\text { Construction and } \\
\text { domestic debris, } \\
\text { casual dumping, } \\
\text { loss }\end{array}$ & 24 \\
\hline 2 & $\begin{array}{l}\text { EP 2 } \\
\text { STP } 3\end{array}$ & $\begin{array}{l}\text { Amber machine-made vessel } \\
\text { glass, clear vessel glass, nails }\end{array}$ & & & Charcoal & $\begin{array}{l}\text { Domestic debris, } \\
\text { casual dumping }\end{array}$ & 8 \\
\hline 2 & $\begin{array}{l}\text { EP } 2 \\
\text { STP } 4\end{array}$ & $\begin{array}{l}\text { Aqua vessel glass, clear } \\
\text { vessel glass, metal lid, foil, } \\
\text { wax, glass tube, burned } \\
\text { wooden board }\end{array}$ & & & $\begin{array}{l}\text { Animal } \\
\text { bone }\end{array}$ & $\begin{array}{l}\text { Domestic debris, } \\
\text { casual dumping, } \\
\text { loss }\end{array}$ & 16 \\
\hline 2 & $\begin{array}{l}\text { EP } 10 \\
\text { STP } 22\end{array}$ & $\begin{array}{l}\text { Metal wire, wire nails, vessel } \\
\text { glass, asphalt }\end{array}$ & & FCR & Charcoal & $\begin{array}{l}\text { Domestic debris, } \\
\text { casual dumping, } \\
\text { natural wildfire or } \\
\text { Native American } \\
\text { prairie burning }\end{array}$ & 6 \\
\hline 2 & $\begin{array}{l}\text { EP } 10 \\
\text { STP } 23\end{array}$ & Wire nail, clear vessel glass & & & Charcoal & $\begin{array}{l}\text { Domestic debris, } \\
\text { casual dumping }\end{array}$ & 3 \\
\hline 2 & $\begin{array}{l}\text { EP 10 } \\
\text { STP 24 }\end{array}$ & Clear vessel glass & & & Charcoal & $\begin{array}{l}\text { Domestic debris, } \\
\text { casual dumping }\end{array}$ & 1 \\
\hline 2 & $\begin{array}{l}\text { EP 11 } \\
\text { STP 27 }\end{array}$ & & & FCR & $\begin{array}{l}\text { Charcoal, } \\
\text { wood, } \\
\text { animal } \\
\text { bone }\end{array}$ & $\begin{array}{l}\text { Natural wildfire or } \\
\text { Native American } \\
\text { prairie burning }\end{array}$ & 4 \\
\hline 2 & $\begin{array}{l}\text { EP 11 } \\
\text { STP } 28\end{array}$ & $\begin{array}{l}\text { Green vessel glass, American } \\
\text { brick, asphalt, wire nail }\end{array}$ & $\begin{array}{l}\text { American machine-cut } \\
\text { nail }\end{array}$ & $\begin{array}{l}\text { FCR, } \\
\text { projectile } \\
\text { point }\end{array}$ & $\begin{array}{l}\text { Charcoal, } \\
\text { animal } \\
\text { bone }\end{array}$ & $\begin{array}{l}\text { Domestic debris, } \\
\text { casual dumping, } \\
\text { Native American } \\
\text { presence }\end{array}$ & 17 \\
\hline 2 & $\begin{array}{l}\text { EP 11 } \\
\text { STP } 29\end{array}$ & Paper, wood & & FCR & $\begin{array}{l}\text { Animal } \\
\text { bone, } \\
\text { charcoal }\end{array}$ & $\begin{array}{l}\text { Loss, casual } \\
\text { dumping, natural } \\
\text { wildfire or Native } \\
\text { American prairie } \\
\text { burning }\end{array}$ & 3 \\
\hline
\end{tabular}




\begin{tabular}{|c|c|c|c|c|c|c|c|}
\hline 2 & $\begin{array}{l}\text { EP } 11 \\
\text { STP } 30\end{array}$ & $\begin{array}{l}\text { Window glass, green vessel } \\
\text { glass, clear vessel glass }\end{array}$ & $\begin{array}{l}\text { Undecorated whiteware, } \\
\text { American machine-cut } \\
\text { nail, wood boards }\end{array}$ & & Charcoal & $\begin{array}{l}\text { Domestic debris, } \\
\text { casual dumping, } \\
\text { possible } H B C \\
\text { presence or } 19^{\text {th }}- \\
\text { century settlement }\end{array}$ & 12 \\
\hline 2 & $\begin{array}{l}\text { EP } 12 \\
\text { STP } 31\end{array}$ & $\begin{array}{l}\text { Composite roof tile, nails, } \\
\text { plastic fragments, window } \\
\text { glass, clear vessel glass }\end{array}$ & & & $\begin{array}{l}\text { Animal } \\
\text { bone }\end{array}$ & $\begin{array}{l}\text { Domestic and } \\
\text { construction debris, } \\
\text { casual dumping }\end{array}$ & 34 \\
\hline 2 & $\begin{array}{l}\text { EP 12 } \\
\text { STP 32 }\end{array}$ & Clear vessel glass & & & & Domestic debris & 2 \\
\hline 2 & $\begin{array}{l}2009 \text { ASCC } \\
\text { monitoring }\end{array}$ & $\begin{array}{l}\text { Iron hinge, amber glass } \\
\text { bottle fragment, window } \\
\text { glass }\end{array}$ & Whiteware ceramics & & $\begin{array}{l}\text { Burned } \\
\text { root or log }\end{array}$ & $\begin{array}{l}\text { Historic refuse } \\
\text { scatter }\end{array}$ & N/A \\
\hline 3 & $\begin{array}{l}\text { EP 1 } \\
\text { STP } 1\end{array}$ & $\begin{array}{l}\text { Amber vessel glass, clear } \\
\text { vessel glass, nails, asphalt } \\
\text { slab }\end{array}$ & & & Charcoal & $\begin{array}{l}\text { Mixed fill to level } \\
\text { the landscape, } \\
\text { domestic debris }\end{array}$ & 9 \\
\hline 3 & $\begin{array}{l}\text { EP 1 } \\
\text { STP 2 }\end{array}$ & Landscape fabric & & & $\begin{array}{l}\text { Animal } \\
\text { bone }\end{array}$ & $\begin{array}{l}\text { Domestic gardening } \\
\text { activities }\end{array}$ & 4 \\
\hline 3 & $\begin{array}{l}\text { EP 9 } \\
\text { STP } 19\end{array}$ & Wire nails, window glass & & & $\begin{array}{l}\text { Animal } \\
\text { bone, } \\
\text { charcoal, } \\
\text { wood } \\
\text { fragments }\end{array}$ & $\begin{array}{l}\text { Sheet trash from } \\
\text { home construction } \\
\text { and domestic } \\
\text { activities }\end{array}$ & 5 \\
\hline 3 & $\begin{array}{l}\text { EP 9 } \\
\text { STP } 20\end{array}$ & $\begin{array}{l}\text { Wire nails, composite roof } \\
\text { tile, window glass, clear } \\
\text { vessel glass, undecorated } \\
\text { whiteware, plastic fragments }\end{array}$ & & & $\begin{array}{l}\text { Animal } \\
\text { bone }\end{array}$ & $\begin{array}{l}\text { Sheet trash from } \\
\text { home construction } \\
\text { and domestic } \\
\text { activities }\end{array}$ & 16 \\
\hline 3 & $\begin{array}{l}\text { EP 9 } \\
\text { STP } 21\end{array}$ & Wire nail & & & & $\begin{array}{l}\text { Construction } \\
\text { activities }\end{array}$ & 1 \\
\hline 3 & $\begin{array}{l}2009 \text { ASCC } \\
\text { monitoring }\end{array}$ & $\begin{array}{l}\text { Ceramic dish fragments, blue } \\
\text { "Bennington" marble }\end{array}$ & & & & $\begin{array}{l}\text { Historic refuse } \\
\text { scatter }\end{array}$ & N/A \\
\hline 4 & $\begin{array}{l}\text { EP } 8 \\
\text { STP } 17\end{array}$ & & & FCR & & $\begin{array}{l}\text { Natural wildfire or } \\
\text { Native American } \\
\text { prairie burning }\end{array}$ & 10 \\
\hline 4 & $\begin{array}{l}\text { EP } 8 \\
\text { STP } 18\end{array}$ & & & FCR & & $\begin{array}{l}\text { Natural wildfire or } \\
\text { Native American } \\
\text { prairie burning }\end{array}$ & 2 \\
\hline
\end{tabular}




\begin{tabular}{|c|c|c|c|c|c|c|c|}
\hline 4 & $\begin{array}{l}\text { EP } 8 \\
\text { STP25 }\end{array}$ & $\begin{array}{l}\text { Machine-made amethyst } \\
\text { vessel glass, window glass, } \\
\text { clear vessel glass }\end{array}$ & & & & Domestic debris & 8 \\
\hline 4 & $\begin{array}{l}\text { EP } 8 \\
\text { STP } 26\end{array}$ & & & FCR & & $\begin{array}{l}\text { Natural wildfire or } \\
\text { Native American } \\
\text { prairie burning }\end{array}$ & 1 \\
\hline 4 & $\begin{array}{l}\text { 1990s-early } \\
2000 \text { s } \\
\text { WSSD } \\
\text { excavations }\end{array}$ & $\begin{array}{l}\text { American brick, concrete, } \\
\text { utility pipes, ceramics, vessel } \\
\text { glass }\end{array}$ & & & Glass bead & $\begin{array}{l}\text { Fill, scraped } \\
\text { landscape, debris } \\
\text { from construction } \\
\text { and demolition of } \\
\text { buildings }\end{array}$ & N/A \\
\hline 4 & $\begin{array}{l}2009 \text { ASCC } \\
\text { monitoring }\end{array}$ & $\begin{array}{l}\text { Overland car emblem, } \\
\text { fragment of blue bird decal- } \\
\text { ware ceramic }\end{array}$ & & & & $\begin{array}{l}\text { Historic refuse } \\
\text { scatter }\end{array}$ & N/A \\
\hline 5 & $\begin{array}{l}\text { EP } 4 \\
16\end{array}$ & $\begin{array}{l}\text { Aqua machine-made vessel } \\
\text { glass, plastics, wire nails, } \\
\text { American brick, clothespin } \\
\text { spring }\end{array}$ & & & $\begin{array}{l}\text { Orange } \\
\text { seed bead }\end{array}$ & $\begin{array}{l}\text { Domestic debris, } \\
\text { loss, casual } \\
\text { dumping, gardening } \\
\text { activities }\end{array}$ & 60 \\
\hline 5 & $\begin{array}{l}\text { EP4 } \\
\text { STP } 7\end{array}$ & $\begin{array}{l}\text { Aqua machine-made vessel } \\
\text { glass, plastics, wire nails, } \\
\text { American brick, glass } \\
\text { marble, landscape fabric }\end{array}$ & & & Coal & $\begin{array}{l}\text { Domestic debris and } \\
\text { fill, loss, casual } \\
\text { dumping, gardening } \\
\text { activities }\end{array}$ & 44 \\
\hline 5 & $\begin{array}{l}\text { EP } 4 \\
\text { STP } 8\end{array}$ & $\begin{array}{l}\text { Amber machine-made vessel } \\
\text { glass, plastics, wire nails, } \\
\text { American brick, composite } \\
\text { roof tile, plumbing part }\end{array}$ & & & & $\begin{array}{l}\text { Domestic trash } \\
\text { dump in corner of } \\
\text { property }\end{array}$ & 68 \\
\hline 5 & $\begin{array}{l}2018 \text { ASCC } \\
\text { excavations }\end{array}$ & & $\begin{array}{l}\text { "Broseley" patterned } \\
\text { Spode ceramic, } 1878 \\
\text { Franklin Arsenal- } \\
\text { manufactured } .45 \text { caliber } \\
\text { rifle cartridge, colored } \\
\text { vessel glass }\end{array}$ & & & $\begin{array}{l}\text { U.S. Army debris } \\
\text { from nearby } \\
\text { Vancouver Barracks }\end{array}$ & N/A \\
\hline
\end{tabular}




\section{Summary of Findings}

Across the five sections I obtained permission to excavate at 12 properties and completed a total of 32 shovel test probes. Within these probes, I located a total of 472 artifacts, plus hundreds of fragments of charcoal, wood, and concrete which were too numerous and fragmentary to count, and therefore are not included in the total artifact count. Artifacts excavated from a total of $2.309 \mathrm{~m}^{3}$ of matrix represented three general time periods: 357 artifacts from the 20th century (Table 6.4), 51 artifacts from the 19th century (Table 6.5), and from the precontact era (Table 6.6) one definitive artifact (projectile point) and 20 more potential artifacts (FCR). Seventy-three artifacts could not be assigned to any time period. A functional typology is included in Appendix M describing artifact types and their interpretation.

Patterning based on artifact distribution and time period is discernable across the landscape, even given the issue of sample size. Volume of matrix excavated generally corresponds with the number of STPs excavated (Tables 6.2 and 6.3), however, the density of artifacts per section is variable (Tables 6.4-6.7). While Section 5 had the lowest volume of matrix excavated it had the highest density of artifacts, 550.9 per $\mathrm{m}^{3}$, and held about one quarter of the total artifacts. Comparatively, while Sections 1 and 2 had the highest volume of matrix excavated and contained the largest percentage of the total artifacts, $62.9 \%$ combined, artifact density of the two sections together was lower than Section 5 alone, at 444.4 artifacts per $\mathrm{m}^{3}$. The middle section, Section 3 , held only $7.4 \%$ of the total artifacts, with a density of 247.1 artifacts per $\mathrm{m}^{3}$. Section 4 held the smallest percentage of the total artifacts, $4.4 \%$, and even with the close proximity of 
Section 4's STPs to the WSSD designated as the site of the first fort, artifact density was only 83.1 per $\mathrm{m}^{3}$.

In addition to variable artifact distribution, change over time across the project area is seen in the tables above. Table 6.4 shows that artifacts from the 20 th century to the present day were found in every section and make up more than two-thirds $(69.2 \%)$ of the total project artifacts, indicating the widespread population growth and residential expansion across the project area beginning in the early 20th century and continuing to the present day. Table 6.5 suggests that there were far fewer occupants of the landscape during the 19th century, with 19th-century artifacts appearing just in Sections 1 and 2 and making up only $11 \%$ of the total artifact count. While very few artifacts (4.4\%) date to the precontact-era (Table 6.6), the projectile point and fire cracked rock found in Sections 2 and 4 are significant reminders of Native American use and management of the landscape.

Interpretation of artifacts per STP (Table 6.8), discussed below in more detail, shows that, before European and American settlement, the upper prairie may have been cultivated by Native Americans as a camas field and FCR found here may signal human activity such as prairie burning, camp hearths, or camas ovens; 19th-century artifacts may mark the location of a British Royal Navy structure in Section 1; and much of the use of the landscape since the 19th century has been related to domestic activities such as home construction, gardening, dumping, and loss. Importantly for this project, no early-19thcentury artifacts were found, with the possible exception of three boards with a possible connection to the HBC discovered in Section 2, discussed below in more detail. 


\section{Section 1}

In this section, I excavated nine STPs at four properties (Table 6.2), and artifacts number 191 (Tables 6.4, 6.5, 6.7). Most artifacts appeared to be related to domestic activities such as loss, dumping, and trash burning (Table 6.8). However, neighbors in Section 1 mentioned to me that the "trash pit" of the first fort existed in this section. This legend appears to stem from the discovery of items such as wooden wagon wheels and cannon balls at a particular property in Section 1. While I could not obtain permission to excavate at the property containing the alleged trash pit, all of the Section 1 properties I excavated were in its vicinity. Despite reports of artifacts found at some of these properties, STPs at EPs 3, 5, and 7 contained scant artifacts, all generally dating to the 20th century (Figure 6.4). Although at least one homeowner mentioned finding blue transferprint ceramics in the yard over the last few decades, during my excavations at these three properties I found no early-19th-century artifacts.

At EP 6, substantial remains dating to the early 19th century were uncovered (Table 6.5). Of the four properties in this section, this was the closest to the property containing what neighbors called the first fort dump. Here, I recorded a mix of modern and historic artifacts, with some items dating to the mid-19th century found between 4-54 centimeters below the ground surface (cmbs). Diagnostic items included metal objects and an American machine-cut nail (Figure 6.5), ceramic sherds (Figure 6.6), and blowninto-mold glassware fragments colored aqua, dark olive green, and amber (Figure 6.7), dating this site to the 1840 s at the earliest. 


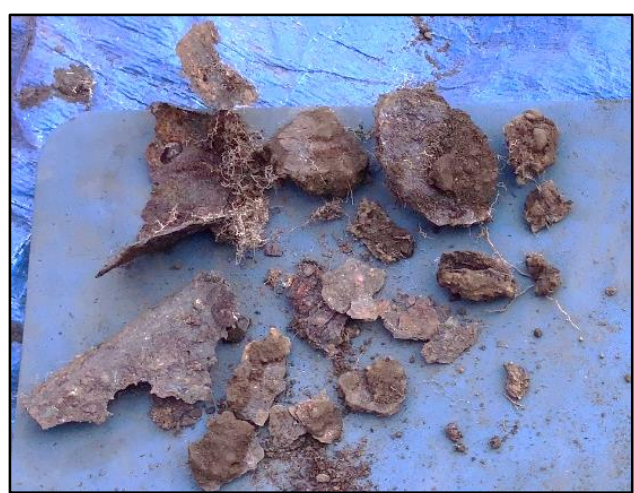

Figure 6.4 Section 1 selected artifacts from EP 3: Burn barrel fragments

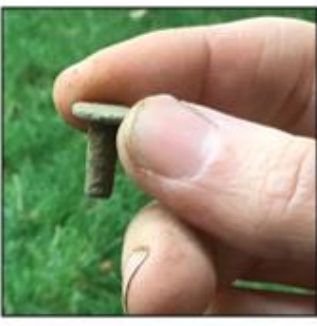

Copper fastener

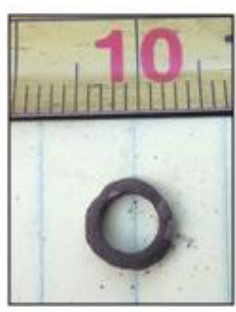

Metal eyelet

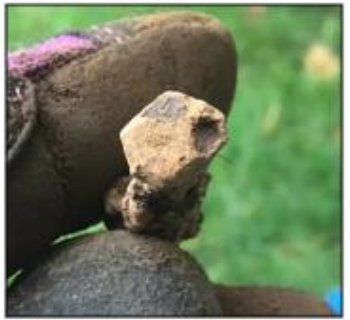

American machine-cut nail

Figure 6.5 Section 1 selected artifacts from STP 12: Metal objects

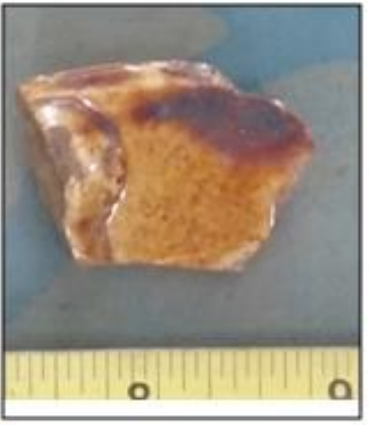

Rockinghamware

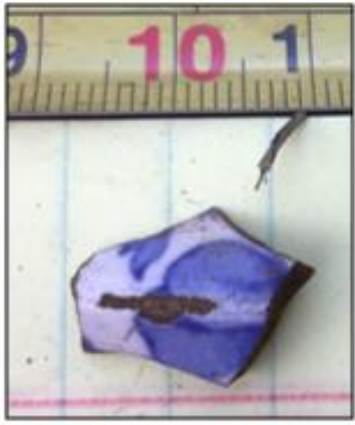

Transferprint

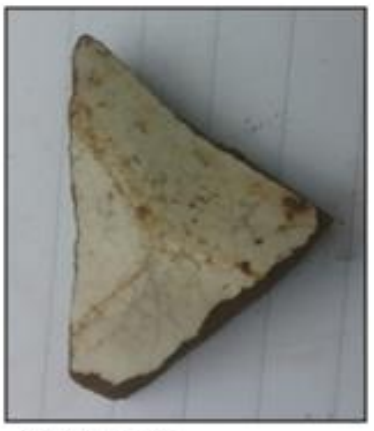

Whiteware

Figure 6.6 Section 1 selected artifacts from STP 12: Ceramics 


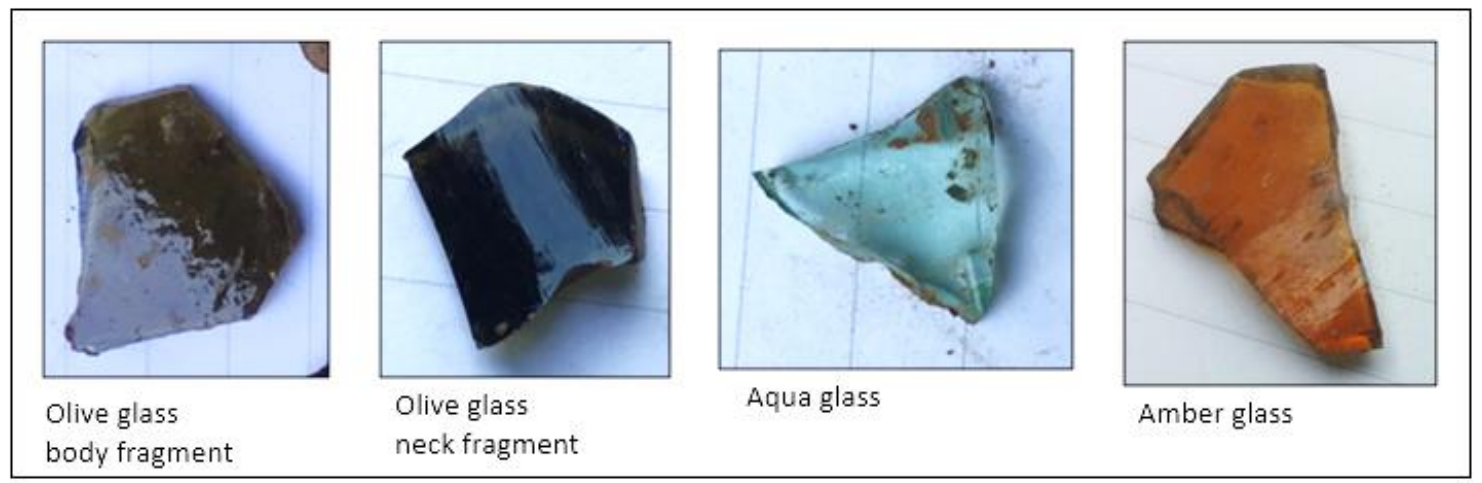

Figure 6.7 Section 1 selected artifacts from STP 12: Blown-into-mold vessel glass

\section{Section 2}

In Section 2, I excavated eleven STPs at four properties (Table 6.2). Artifacts total 106, and 20th-century domestic debris (Figure 6.8) at EPs 2, 10, and 12 suggest deposition through loss and casual dumping (Table 6.8). FCR found at EPs 10 and 11 may signal prairie burning, camp hearths, or cams ovens. At EP 11, I did not find any artifacts that could definitely date to $1825-1829$, however, there are a few items of interest. First, in STP 28, I found a projectile point (Figure 6.9) that I analyzed as a basal notched, barbed, diverging stem, Lower Columbia Type Projectile Point Type 4 (Pettigrew 1981). While the context in which this point was found was disturbed by excavation for an early sewer line, the homeowner and I believe that, even though the point may not have vertical provenience, it most likely has archaeological origins in these sediments; it was simply scooped out for the sewer line work, and then shoveled back in. While the presence of FCR may signal Native use of the area, its human-made versus natural origin is ambiguous, as mentioned above, and this projectile point is the one piece of definitive evidence I found during this project of American Indian occupation of this 
landscape. During the ethnographic interviews, residents mentioned finding numerous "arrowheads" in the project area over the decades, and my find archaeologically corroborates these stories. Additionally, two American machine-cut nails (Figure 6.10) were found, as well as a sherd of undecorated white earthenware ceramic. In this area, these artifact types signal activity in the late 19th to early 20th centuries and are potentially related to homesteading or farming activity.

Intriguingly, in the final level of STP 30, I found three boards in intact sediments at $65 \mathrm{cmbs}$. I was able to remove one board from the STP. It appears to be Douglas fir and is hand-hewn with hand-cut edges and two small nail holes (Figure 6.11). The board was aligned end-to-end with two other boards that remained in the walls of the unit in a north-south orientation. No other artifacts were found with the boards, and they were burned in areas. Combined with the documentary and ethnographic evidence (see Chapter 5: Results of Public Outreach and Ethnography), it is possible they may have some association with the first Fort Vancouver. Because these boards constitute the only artifacts from my excavations within this section that may date to the HBC-era, I compared them with wooden items found during excavations at the second Fort Vancouver.

Uses of boards at the second Fort Vancouver that seemed unlikely matches for the boards I found include wooden flooring (Thomas and Hibbs 1984:658), building footings (Hoffman and Ross 1974a:10), and flagstaff cribbing (Hoffman and Ross 1973b:4), because these types of boards would generally be longer, wider, and thicker than the Section 2 boards. The second fort had wooden drainage troughs (Hoffman and Ross 
1974b:33), however I do not believe the configuration of the Section 2 boards matches the characteristics of these structures. Building siding at the second fort was longer and thinner (Hoffman and Ross 1974a:57) than the Section 2 boards, and lath boards found in excavations of the Chief Factor's House at the second fort (Hoffman and Ross 1973a:44) had narrower measurements than the Section 2 boards.

Signaling bells were likely used beginning in the earliest days of occupation at the second fort (Hoffman and Ross 1973b:20), so it is possible the first fort also had a belfry, important for coordinating personnel and activities (Hoffman and Ross 1973b:27). The belfry at the second fort displayed horizontal cleats attached along its mast for climbing up to reach the bell (Hoffman and Ross 1973b:22), and Hoffman and Ross (1973b:25) estimate dimensions of the cleats at $1.5 \mathrm{ft}$ long by 0.5 feet wide. Possibly, the Section 2 boards are belfry mast cleats, and their slightly smaller dimensions could be due to differing construction techniques. The Section 2 boards could also possibly be from shelving or platforms in a fort building. Hoffman and Ross (1974a:85) reason that the Powder Magazine at the second fort likely contained wooden platforms to raise black powder barrels and kegs of the ground, and the Section 2 boards may well have served a similar purpose, or even kitchen shelving possibly. Finally, the linear alignment of the boards could indicate fencing or a pen to enclose livestock near the fort. Additional excavation in the vicinity of this find would be necessary to confirm the age and function of the boards found in Section 2. 


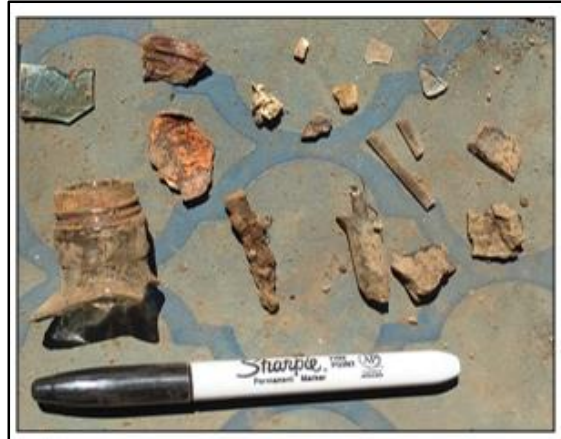

Household debris (Sharpie provides scale)
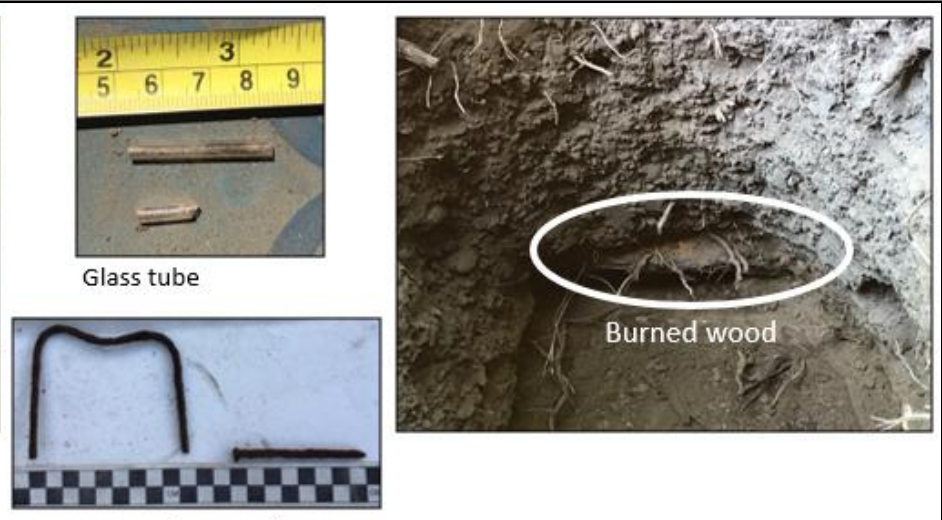

Bent wire and wire nail

Figure 6.8 Section 2 selected artifacts: Domestic debris

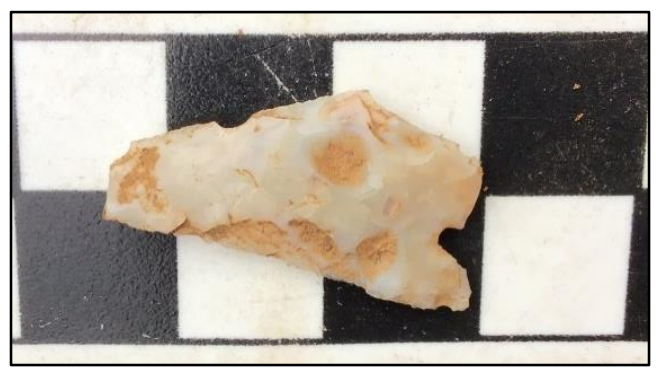

Figure 6.9 Section 2 selected artifacts from EP 11: Lower Columbia Projectile Point Type 4, approximately $25 \mathrm{~mm}$.

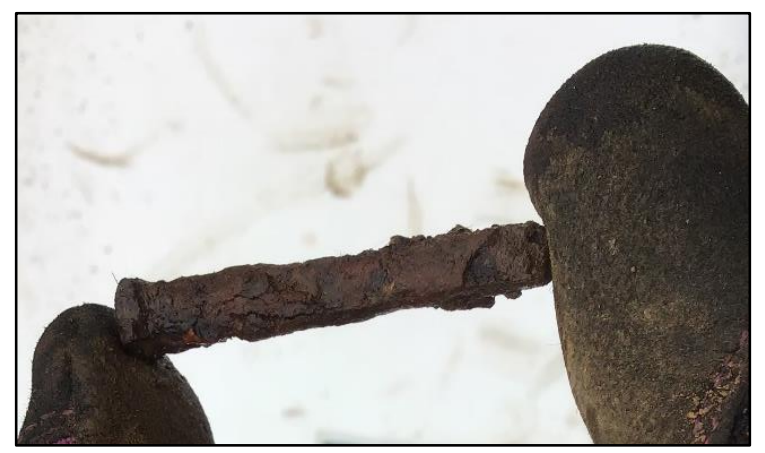

Figure 6.10 Section 2 selected artifacts from EP 11: American machine-cut nail 


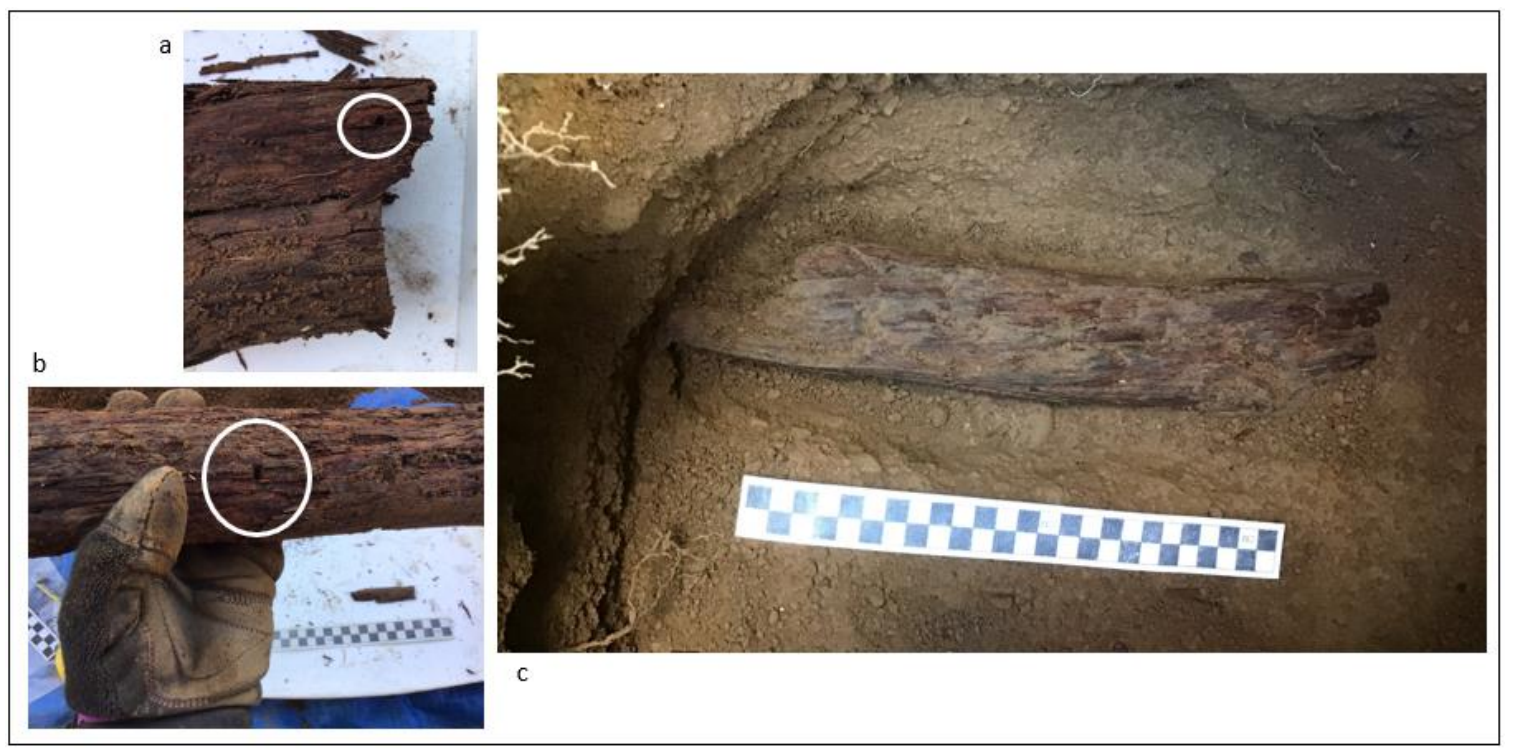

Figure 6.11 Section 2 selected artifacts from EP 11: Board. a. Nail hole 1 and cut edge, b. nail hole 2, c. board in situ, measuring $36 \mathrm{~cm} \mathrm{x} 6.5 \mathrm{~cm} \mathrm{x} 4 \mathrm{~cm}$

Section 3

In Section 3, I excavated five shovel tests at two properties (Table 6.2). Artifacts total 35 and date to 20th-century domestic activities (Tables 6.4 and 6.8). Undecorated whiteware (Figure 6.12) found in STP 20 could date to the 19th century, however its deposition with 20th-century items makes its provenience ambiguous. At EP 1, the base of STP 1 contained an asphalt slab (Figure 6.12) at $70 \mathrm{cmbs}$. When I mentioned this to the homeowners, they recalled that side of the property had once been covered by a driveway which was demolished to add on to the home, making the slab likely a remnant of a past driveway. 


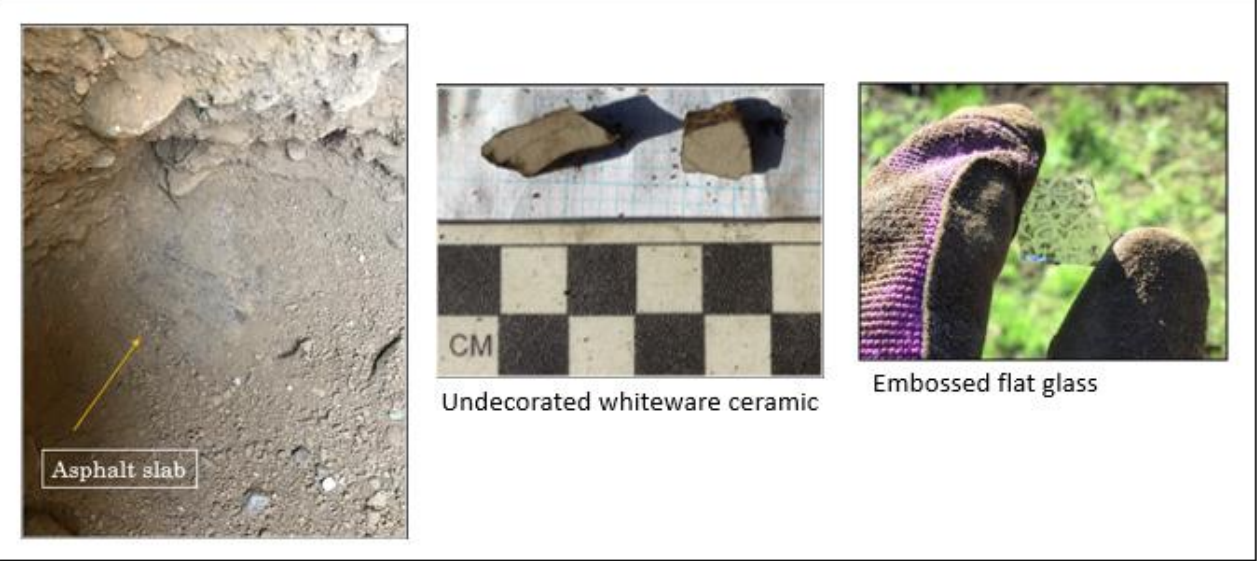

Figure 6.12 Section 3 selected artifacts: Domestic debris

\section{Section 4}

Section 4 includes the WSSD, as well as a sign designating the WSSD campus as the site of the first Fort Vancouver. In Section 4, I excavated four STPs at a single property (Table 6.2), and artifacts total 21. Three of the four STPs yielded zero artifacts, except for possible fire cracked rock (FCR). These FCR (Table 6.6) are small rounded cobbles, discovered in gravelly matrix similar to deposits found at the second Fort Vancouver, on top of B-Horizon sediments, and displaying discoloration and angular fracturing. It is possible FCR on this plain signify evidence of controlled prairie burning by Native Americans to promote growing conditions for camas, or could signal camp hearths or camas ovens. FCR may also be from natural burning events (Table 6.8).

Excavations for my project took place at a property adjacent to the WSSD, and if the first fort was located where the WSSD now stands, artifacts from the first fort would likely be found at EP 8. I placed two of the STPs near the fence line closest to the WSSD, one near the middle of the backyard, and one on the east side of the backyard. Only one 
STP contained diagnostic artifacts, including five fragments of amethyst vessel glass (Figure 6.13), possibly from a wide-mouth bottle or jar, manufactured by machine. Manufacture of machine-made amethyst vessel glass dates from 1905 to the 1930s (Society for Historical Archaeology 2018), meaning this glass is not associated with the first Fort Vancouver. The glass could, however, be related to early occupation of the home built in the 1930s, or to the history of the WSSD.

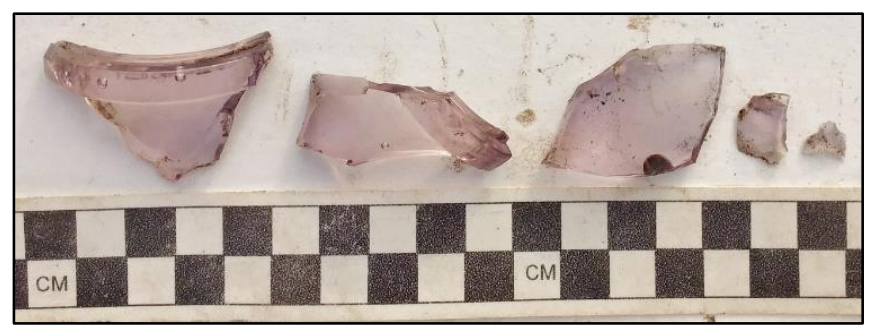

Figure 6.13 Section 4 amethyst glass fragments

\section{Section 5}

In Section 5, I excavated three shovel test probes at a single property (Table 6.2). Artifacts recovered from these probes total 120 , and consist mainly of 20th-century items related to domestic use (Table 6.4). The current residents commented that this was the first home built on the property, and that prior to home construction the land was used by an adjacent neighbor as a gardening space for several decades. Two artifacts could potentially date to the early 19th century: a relatively large piece of coal measuring almost $6 \mathrm{~cm}$ (about $2.25 \mathrm{in}$.) found at a depth of $20 \mathrm{cmbs}$, and an orange-colored glass seed bead measuring $2 \mathrm{~mm}$ (0.08 in.) discovered at a depth of $0-20 \mathrm{cmbs}$ (Figure 6.14). Both of these artifact types have long periods of usage, and were found in contexts with 
artifacts of later time periods. Their location at shallow depths suggest that they may have been deposited here relatively recently, possibly in imported fill, so they are unlikely to be associated with the first Fort Vancouver.

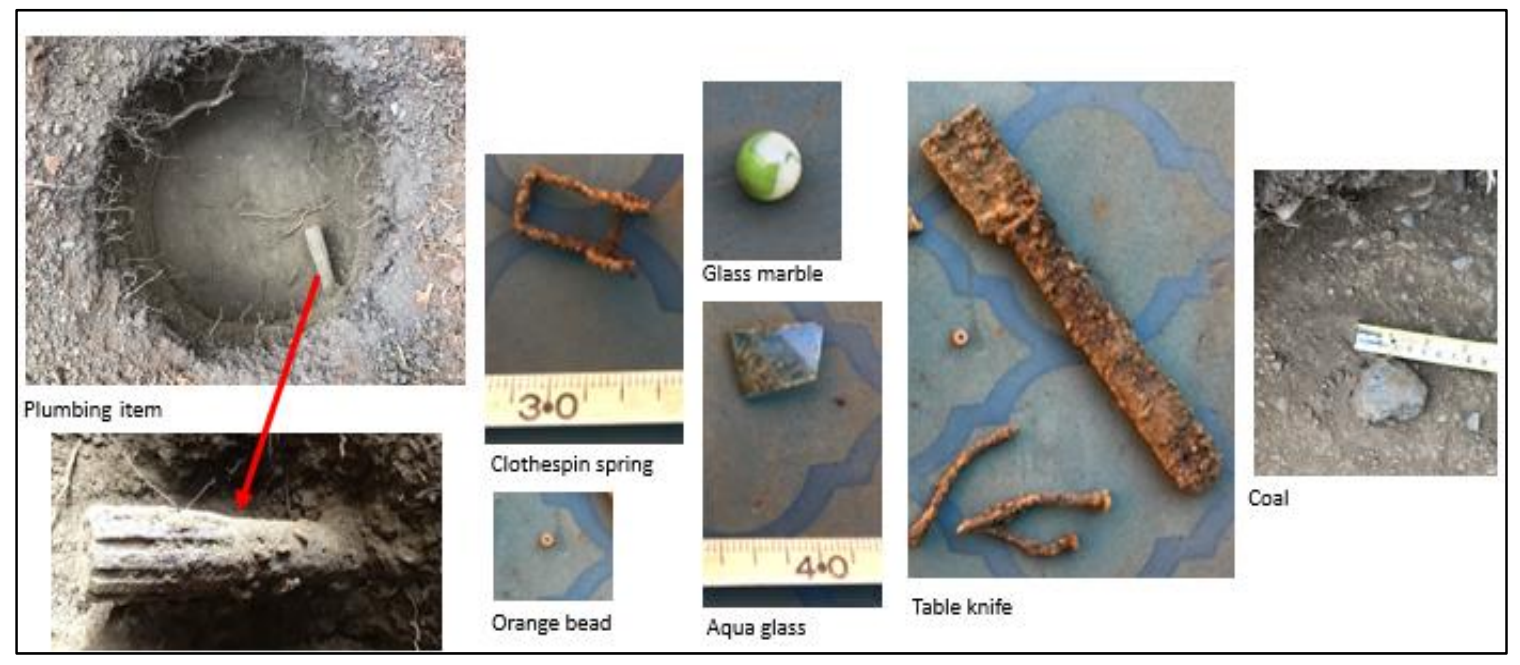

Figure 6.14 Section 5 selected artifacts: Domestic debris

\section{Archaeological Discussion}

This project adds to the archaeological knowledge of the project area by building on previous archaeological investigations, moving research a step closer in finding evidence of the first Fort Vancouver. The lack of definitive early-19th-century finds during formal investigations across the project area demonstrates the challenges inherent in this archaeological search. The short life of the first fort means its archaeological footprint is likely weak, making the search for its remains a daunting task. In addition to the fort's ephemerality, the abundance of homes and other structures built on widespread private property increases the challenges in finding any remaining archaeological 
evidence. Previous formal investigations have never recovered any definitive artifacts related to the first fort, and during this project, I excavated only one potential, although non-diagnostic, piece of evidence, the boards discovered at EP 11 in Section 2.

A sign at the campus of the WSSD states that the first Fort Vancouver was located where the WSSD now stands on the bluff overlooking the Columbia River, however, evidence for this claim remains elusive. Previous archaeological investigations discovered no indication of the fort near the WSSD, and during my project I did not find 19th-century artifacts near the WSSD, located in project Section 4. The dearth of artifacts from the early 19th century in this locale supports the idea that the first fort was likely not located at the current location of the WSSD.

While the archaeological search has thus far yielded few clues to the location of the first fort, documentary and ethnographic evidence discussed in previous chapters point to the first fort having existed in Section 2 of the project area. Location information in the documentary record signals Section 2 as the most likely location of the first fort. During my ethnographic study, residents mentioned finding early-19th-century artifacts in Section 2, and that the archaeologist Louis Caywood professed the well of the first fort at a property in Section 2 in the late 1940s.

Although one focus of this research was in finding evidence of the first Fort Vancouver, the HBC-era is one of many pieces of the story of the project area landscape. A number of artifacts from my excavations continue the story beyond the HBC into the mid-19th century, particularly in the easternmost section of the project area. In Section 1, residents believe that one property holds evidence of the remains of an early- $19^{\text {th }}$-century 
Hudson's Bay Company midden, or what they called the "trash pit" of the first Fort Vancouver. Excavating at a property adjacent to the potential midden, I did find 19thcentury artifacts. However, instead of early-19th-century items related to the first Fort Vancouver, my excavations revealed artifacts associated with a later period, more consistent with the potential remains of a British Royal Navy officer's home, a late-1840s yurt-like structure built on the upper prairie called Dundas' Castle, or Dundas' Folly (Erigero 1992:123), discussed in more detail in Chapter 2: Background. Since no other structures are noted in the vicinity until around 1900, a logical interpretation is that the 19th-century artifacts recovered at EP 6 are remains of occupation at Dundas' Folly. However, as this inference is based on very limited information (shovel tests), it should be considered hypothetical.

The history of the landscape over time is reflected in all of the artifacts found during this project. Most of the artifacts excavated during this project and others are related to domestic activities at 20th-century households, affirmation of the influx of occupants beginning at the end of the 19th century with a dramatic rise in residential growth during the 20th century. Precontact artifacts give clues to the occupation of the landscape deep into the past, providing evidence of Native American use of the upper prairie, possibly as a fire-maintained prairie.

Beyond the basic archaeological search for material remains, this was also a study in backyard archaeology with the participation of residents on private property. Archaeologists know that there are many misconceptions in the public's understanding of archaeology (Merriman 2004b; Little 2007b; Rockman and Flatman 2012), and this 
project demonstrated to residents what archaeological field research can look like and ways in which we use scientific methods in our research. I invited the residents at each property to join me during excavations, or to simply watch and ask questions. Most residents spent at least a short time observing and inquiring about my work, and some spent much of the day with me, asking questions about my methods and expressing great interest in the artifacts I was finding. Although residents spent differing amounts of time with me during fieldwork, by the end, all had gained an idea of what this type of archaeological testing entails (See Chapter 5: Results of Public Outreach and Ethnography), increasing their understanding of archaeological processes and methods and helping legitimize the contributions that archaeological research makes through its controlled and scientific process (Moe 2002).

Excavation with residents on private property was a positive experience. Working with residents to archaeologically excavate on their property during this project increased these residents' appreciation for archaeological research and what is learned from this research. They now have a better understanding of the how this landscape has looked and changed over time and are more aware of the clues to the past that lie under the ground where they walk every day. I believe that by participating in this project, these residents see their role as stewards of this landscape, and that they feel invested in the history and heritage of this area shared by people over thousands of years. After witnessing archaeological research in action, and working with an archaeologist throughout this project, I trust that they will now feel comfortable seeking out professional advice and analysis about any clues to the past they may discover on their properties. Instead of 
artifacts being thrown out or hidden away in basements, there is now the chance that these stakeholders in area history and heritage will be the ones to find material evidence of the first Fort Vancouver, and to make their discoveries known. 


\section{Chapter 7: Conclusion}

With this project, I set out to explore ways of increasing archaeology's relevance in the modern world. Methods used were intended to elicit participation of stakeholders with varying levels of interest in this work, and to measure the effects of participation on individuals and communities. Achievement of project goals included three strategies: involvement of Fort Vancouver's resident community in an archaeological search for material remains of the first Fort Vancouver; an ethnographic study of the effects of involvement on feelings toward heritage, archaeology, and place attachment; and an exploration of public outreach methods in archaeological research.

Although clues from the archaeological search alone could not establish the exact location of the first Fort Vancouver, evidence from the documentary, ethnographic, and archaeological record combined to narrow its location. Documents are clear that the fort stood on the upper prairie, and I believe they point to its location in project area Section 2. During the ethnographic part of this project, particularly the informational interviews, artifacts found by residents and reports of the undocumented excavations of Louis Caywood place the fort in Section 2. In addition, the wood boards I found at Section 2's EP 11 suggest 19th-century activity and are potential evidence of HBC occupation.

The archaeological portion of the project served as a vehicle for collaboration with community members and for creating connections linking individuals with area history and the discipline of archaeology (Derry and Malloy 2003). Partnerships formed with community members in archaeological research built a deeper historical context through the archaeological search for material culture left here by people in the past. 
Archaeology links the tangibles of material culture to the intangibles of human connection (Little 2007c:146), and the unearthing of material culture through archaeological research during this project inspired people to think about area history and the heritage of people who have occupied the landscape over thousands of years. Unfortunately, the concept of heritage has long been associated with "value judgements based on indices of identity, locality, territory, ethnicity, religion, and economics" (Meskell 2009:23). Heritage has, in effect, been used to divide, separate, and exclude groups and individuals in various places and situations. My goal for this project was to emphasize the inclusiveness of heritage and to engage a wide range of people from varying backgrounds to reveal commonalities based on place. By situating particular events and people in the larger story of area history (Little 2007c:146), this project illuminated the role archaeology can play in society as a whole and in the lives of individuals. Former communities influenced and are reflected in the current neighborhoods, and my project helped strengthen community bonds by using archaeology to reveal the interconnectedness of people over long expanses of time based on place.

While my ethnographic study indicates that involvement in this research did not necessarily change participants' minds about heritage, archaeology, and place attachment, interview data revealed that being part of this project affected participants by deepening interest in, curiosity about, and appreciation for area history and the role of archaeology in their lives. Archaeologists ponder how to make archaeology relevant in everyday life, and I found that the relevancy of archaeology today lies in its ability to 
illuminate the connections between people across time. Interconnections based on place can create ties between individual and groups who might otherwise have apparently little in common. The place-based human connection across time reveals a common ground, creating bonds between the resident community with those in the past and their neighbors in the present.

Those who responded to participate in excavation and interviews were a fairly homogenous group of white, middle-class homeowners. Some participants encouraged neighbors and friends who were renters and/or ethnic minorities to work with me. None would, and the main reason I was given was that these residents felt that the history of the area did not belong to them. They felt it was not the heritage of their own people, or that as renters they did not own a stake in the neighborhood so had nothing to contribute to this study. Attempts to reassure these residents that I did indeed value their viewpoints, thoughts, and feelings did not persuade them and I was unable to convince residents from diverse backgrounds to participate in the study. Perhaps feelings of disenfranchisement has roots in the notion of cultural diversity which essentializes and differentiates cultures by dividing and separating groups from each other while emphasizing differences (Holtorf 2017:5). An understanding of how and why people relate to and think about heritage and place is critical for practicing more relevant and inclusive archaeology, and heritage and archaeological research based on place can potentially be a vehicle of inclusion and social glue. 


\section{Lessons Learned}

"Backyard archaeology" can tell the story of the landscape through the lens of occupants of the land in the past and in the present. But, in projects like this one, it can be challenging to encourage property owners to participate. The most significant limitation in this project was the difficulty in recruiting a larger number and more diverse group of participants for excavation and interviews. As Wright (2015) also found, my conversations with project area residents indicate that some obstacles preventing participation stemmed from mistrust of archaeologists, misperceptions about the consequences of archaeological investigation on private property, and feelings of exclusion from neighborhood heritage. Use of archaeological ethnography methods to gain a better understanding of how non-archaeologists view archaeology (Edgeworth 2006:14) can help overcome obstacles in engaging with communities and individuals, and this project's research led me to the following observations.

1. Earning trust and acceptance in a community takes time. The scope and limitations of this work as a Master's thesis did not allow for the in-depth, long-term commitment that a true ethnographic study requires. Ideally, research would take place over multiple years to foster relationships and gain trust amongst community members, increasing the number of people willing to participate, and ultimately making the research and results more robust and meaningful. Even so, during this short project, I witnessed increased trust in and respect for the research, showing that even a small amount of interaction goes a long way toward creating and strengthening bonds between communities and researchers. 


\section{Feelings of exclusion from place-based area heritage and from archaeological}

research are difficult to overcome. Many feel excluded from traditional exclusive notions of heritage and archaeology. Research emphasizing interconnectedness can promote a powerful means of inclusion to involve all stakeholders especially those who feel disenfranchised. Inclusive research requires thoughtful development of methods to include stakeholders and to allow for stakeholders to experience heritage on their own terms (Holtorf 2017:10).

3. Multiple, creative, and personal outreach methods are necessary to reach a diverse audience. The outreach methods I used - newspaper articles, flyers, advertisement through the Fort Vancouver NHS, public presentations, mailings, school presentations, and social media - were not enough to reach the diverse audience I had hoped to reach. In a repeat of this project, I would develop more creative ways to reach out to more members the resident community. Ideas include making door-todoor visits to personally engage with individuals, and inviting residents to meet-andgreet sessions. Some project participants who hesitated to participate at first, said that after making a personal connection, through meeting me and talking about project details in person, they felt very comfortable being involved with the project. I realize the key to engagement in archaeological research, just as in connecting to the past, is to create opportunities to help people go beyond seeing archaeologists simply as researchers and scientists to feeling a connection to archaeologists as people. 


\section{Future Research}

Attempts to locate material remains of the first Fort Vancouver have been iterative, each providing new information concerning where the fort may or may not have been located. As the latest iteration in the search, my project will likely not be the last. This project built on previous investigations, and others will build on mine, as the story of the project area archaeologically unfolds in the future.

The potential for continuing work in the project area lies not only in the archaeological search, but also in the ethnographic study. My research indicates that every person feels connected to heritage, although the definition of that heritage is highly personal and varies at individual and community levels. Definitions of heritage are often based on feelings of exclusion and inclusion in all kinds of communities, stories, and representations. A critical question that cropped up in the course of my research concerns the relationship between archaeological research and people who feel disenfranchised from the traditional ways that history and heritage are presented and available. Issues like class, ethnicity, renting vs. homeownership, age, and distrust of academic research create disparities in the accessibility of historical, heritage, and archaeological research and in inclusion in place-based heritage. Examination of this question of disenfranchisement was not in the scope of this project; however, disenfranchisement based on various factors appeared as a recurrent theme throughout the archaeological and ethnographic parts of the project, and warrants a critical examination in the quest to make archaeology relevant and meaningful to diverse audiences and communities. Focusing on community heritage based on place may be one way to foster feelings of inclusion for all. 
The focus and methods of this project are not limited to this particular area; this type of project could translate anywhere. While the search for the first Fort Vancouver is a somewhat high-profile case study, projects need not be so "grand." History is everywhere, and people can feel connections to the stories of the past in any place. I observed during my work that, when connections with people in the past based on place are brought to light, people become fascinated with the history of the place where they live and want to learn about the people and events that came before from the smallest to the largest stories. The more often projects like mine are repeated in communities across the country and world, the more people in the present can connect to people in the past, increasing the relevancy, meaningfulness, and support of archaeological research.

\section{Concluding Remarks}

This project positively impacted participants and illuminated an eagerness for local archaeological research and information. Participants responded enthusiastically to involvement in excavation, and the number of times the word "fun" was mentioned in follow-up interviews demonstrates how much these residents enjoyed the project.

Beyond enjoyment, participants deepened their interest in and appreciation for the relevancy of archaeological research and realized connections to people across time based on place. Projects like this one conducted on private property are rare, but I believe with thoughtfulness and creativity, archaeologists can use results of this research as a model for making archaeology relevant to people everywhere in their everyday lives. 


\section{References}

Abbott, Carl

2018 Vanport. The Oregon Encyclopedia, Portland State University and the Oregon Historical Society, Portland <https://oregonencyclopedia.org/articles/vanport/>. Accessed 11 February 2019.

Abel, Kerry

2012 Remembering the War of 1812. Canadian Parliamentary Review 35(3).

Alley, B.F. and J.P. Munro-Fraser

1983 Clarke County Washington Territory 1885. Post Publishing Company, Camas, WA.

American Anthropological Association

2012 Methods and Ethics. American Anthropological Association, Arlington, VA $<$ https://www.americananthro.org/LearnAndTeach/Content.aspx?ItemNumber $=2645 \&$ navItemNumber=652> . Accessed 8 September 2019 .

Angrosino, Michael

2005 Prospects in Ethnographic Research. Waveland Press, Long Grove, IL.

Atalay, Sonya

2006 Indigenous Archaeology as Decolonizing Practice. American Indian Quarterly 30 (3-4):280-310.

Atalay, Sonya

2012 Community-Based Archaeology: Research with, by, and for Indigenous and Local Communities. University of California Press, Berkeley.

Baba, Marietta L.

2000 Theories of Practice in Anthropology: A Critical Appraisal. NAPA Bulletin 18:14-28.

Barton, Christopher and Patricia Markert

2012 Collaborative Archaeology, Oral History, and Social Memory at Timbuctoo, New Jersey. Journal of African Diaspora Archaeology and Heritage 1(1):79102.

Bartoy, Kevin M.

2012 Teaching through Rather than about: Education in the Context of Public Archaeology. In The Oxford Handbook of Public Archaeology, Robin Skeates, 
Carol McDavid, and John Carman, editors, pp. 552-565. Oxford University

Press, Oxford, England.

Boyd, Robert T.

1975 Another Look at the "Fever and Ague" of Western Oregon. Ethnohistory 22(2):135-154.

Brown, Marley III

1973 The Use of Oral and Documentary Sources in Historical Archaeology: Ethnohistory at Mott Farm. Ethnohistory 20(4):347-360.

Brown, Steve

2012 Toward an Archaeology of the Twentieth-Century Suburban Backyard. Archaeology in Oceania 47(2):99-108.

Carman, John

2006 Digging the Dirt: Excavation as Social Practice. In Ethnographies of Archaeological Practice: Cultural Encounters, Material Transformations, Matt Edgeworth, editor, pp. 95-102. Altamira Press, Lanham, MD.

Caywood, Louis R.

1967 Post-1800 Sites: Fur Trade. Historical Archaeology 1:46-48.

City of Vancouver

2016 Population/ Households per Neighborhood 2016 Estimate. City of Vancouver, Vancouver, WA

<https://www.cityofvancouver.us/sites/default/files/fileattachments/city_mana ger039s_office/page/1483/population_households_per_neighborhood_2016_es timate_.pdf $>$. Accessed 7 October 2019.

Clark County Washington

2020 How Much Rainfall Do We Get in Vancouver? Public Works, Clark County, WA <https://www.clark.wa.gov/public-works/faq/how-much-rainfall-do-weget-vancouver $>$. Accessed 17 January 2020.

Clarke County

1888 Map of Clarke County. On File at Fort Vancouver National Historic Site.

Clarke, Samuel Asahel

1905 Pioneer Days of Oregon History. J. K. Gill Company, Portland, OR.

Clearman, Amy

2017a Searching for the First Fort Vancouver. Portland, OR $<$ firstfortvancouver.com>. 
Clearman, Amy

2017b Heritage in the Community: Exploring Residents' Attitudes about Heritage and Archaeology in an Urban Neighborhood. Academic paper, Department of Anthropology, Portland State University, Portland, OR.

Cole, Trudie

2015 Understanding and Assessing the Theories behind Public Education. Public Archaeology 14(2):115-136.

Colón, Justin B.

2018 Archaeological Survey of the Grand Boulevard Apartments Project Area, City of Vancouver, Washington. Report for Tim Lee Leeway Development from Archaeological Services, Vancouver, WA.

Colwell, Chip

2016 Collaborative Archaeologies and Descendant Communities. Annual Review of Anthropology 43:113-27.

Collwell-Chanthaphonh, Chip

2012 Archaeology and Indigenous Collaboration. In Archaeological Theory Today, 2nd edition, Ian Hodder, editor, pp. 267-291. Polity Press, Malden, MA.

Conforti, Maria Eugenia, Patricia Madrid, Mariano Bonomo and Luciano Prates

2013 The Public Communication of Science and Non-Formal Education within the Framework of Public Argentine Archaeology: The Case of Archaeology Workshops. Public Archaeology 12(1):27-47.

Copeland, Tim

2004 Presenting Archaeology to the Public: Constructing Insights On-Site. In Public Archaeology, Nick Merriman, editor, pp. 132-144. Routledge, London, England.

Costello, Julia G.

1998 Bread Fresh from the Oven: Memories of Italian Breadbaking in the California Mother Lode. Historical Archaeology 32(1):66-73.

Cubitt, Geoffrey

2007 History and Memory. Manchester University Press: Manchester and New York.

Cox, David, W.

2008 State of Washington Site Inventory Form 45CL805. Report for Washington State Department of Archaeology and Historic Preservation, Olympia. 
Cressey, Pamela J., Ruth Reeder, and Jared Bryson

2003 Held in Trust: Community Archaeology in Alexandria, Virginia. In Archaeologists and Local Communities: Partners in Exploring the Past, Linda Derry and Maureen Malloy, editors, pp. 1-17. Society for American Archaeology, Washington, D.C.

Daehnke, Jon Darin

2002 Public Outreach and the "Hows" of Archaeology: Archaeology as a Model for Education. Master's Thesis, Department of Anthropology, Portland State University. PDX Scholar, Portland, OR.

Deetz, James

1988 American Historical Archaeology: Methods and Results. Science 239(4838): 362-367.

DeLyria, David

2000 Archaeological Predetermination Report ASCC\# 00355. Report for Washington State Department of Archaeology and Historic Preservation, Olympia.

Derry, Linda

2003a Concluding Remarks. In Archaeologists and Local Communities: Partners in Exploring the Past, Linda Derry and Maureen Malloy, editors, pp. 185-188. Society for American Archaeology, Washington, D.C.

Derry, Linda

2003b Consequences of Involving Archaeology in Contemporary Community Issues. In Archaeologists and Local Communities: Partners in Exploring the Past. Linda Derry and Maureen Malloy, editors, pp. 19-29. Society for American Archaeology, Washington, D.C.

Derry, Linda and Maureen Malloy (editors)

2003 Archaeologists and Local Communities: Partners in Exploring the Past. Society for American Archaeology, Washington, D.C.

Deur, Douglas

2012 An Ethnographic Overview of Groups with Ties to Fort Vancouver National Historic Site. Northwest Cultural Resources Institute Report No. 15 for National Park Service, Vancouver, WA.

Edgeworth, Matt

2006 Preface. In Ethnographies of Archaeological Practice: Cultural Encounters, Material Transformations, Matt Edgeworth, editor, pp. xi-xvi. Altamira Press, Lanham, MD. 
Ellis, David V.

1993 Evaluation of the Potential for Archaeological Deposits Associated with the 1825-1829 Fort Vancouver at the Washington School for the Deaf, Vancouver, Washington: Historical Literature Review, Report No. 43. Report to Washington Department of General Administration, Olympia, from Archaeological Investigations Northwest, Portland, OR.

Ellis, David V., David DeLyria, and Judith S. Chapman

1994 An Evaluation of the Potential for Archaeological Deposits Associated with the 1825-1829 Fort Vancouver at the Washington State School for the Deaf, Vancouver, Washington: Archaeological Field Studies, Letter Report \#63. Report to Washington Department of General Administration, Olympia, from Archaeological Investigations Northwest, Portland, OR.

Erigero, Patricia C.

1992 Cultural Landscape Report: Fort Vancouver National Historic Site, Volume 2. National Park Service, Department of the Interior, Cultural Resources

Division, Pacific Northwest Region, Seattle, WA.

Ervin, Alexander

2005 Applied Anthropology: Tools and Perspectives for Contemporary Practice. 2nd edition. Pearson, Boston, MA.

Flannery, Amanda

2013 Oral History and Archaeology of the Keith's Siding Site Location. Master's thesis, Department of Anthropology, University of Wisconsin-Milwaukee. Proquest Dissertations, Ann Arbor, MI.

Freed, Robert A.

2002 Predetermination Report: Washington School for the Deaf 1344203. Report to Washington State Department of Archaeology and Historic Preservation, Olympia.

Fritz, John M. and Fred T. Plog

1970 The Nature of Archeological Explanation. American Antiquity 35(4):405-412.

Gadsby, David A. and Robert C. Chidester

2007 Heritage in Hamden: A Participatory Research Design for Public Archaeology in a Working-Class Neighborhood, Baltimore, Maryland. In Archaeology as a Tool of Civic Engagement, Barbara A. Little and Paul A. Shackel, editors. AltaMira Press, Lanham, MD.

Gall, Alexander and Michelle Lynch 
2009 Results of Archaeological Monitoring of the Riverview Heights Sewer Extension Project, Vancouver, Clark County, Washington. Report to City of Vancouver, Washington, from Archaeological Services of Clark County, Vancouver, Washington.

Gall, Alexander and Jeff Maceyko

2014 Archaeological Predetermination Report: Summit Construction and Road One Intermodal Logistics. Report to Washington State Department of Archaeology and Historic Preservation, Olympia, Washington, from Archaeological Services of Clark County, Vancouver, Washington.

Garden, Mary-Catherine E.

2006 The Heritagescape: Looking at Landscapes of the Past. International Journal of Heritage Studies, 12(5): 394-411.

Garrison, David H.

2015 A History of Transplants: A Study of Entryway Gardens at Amache. Master's thesis, Department of Anthropology, University of Denver. Proquest Dissertations, Ann Arbor, MI.

Gazin-Schwartz, Amy and Cornelius Holtorf

1999 ‘As Long as Ever I’ve Known it...': On Folklore and Archaeology. In Archaeology and Folklore, Amy Gazin-Schwartz and Cornelius Holtorf, editors, pp. 3-25. Routledge, London, England.

Gifford, Robert

2014 Environmental Psychology Matters. Annual Review of Psychology, 65(1):541579.

Hamilakis, Yannis and Aris Anagnostopoulos

2009 What is Archaeological Ethnography? Public Archaeology: Archaeological Ethnographies 8(2-3):65-87.

Hamilton, Paula and Linda Shopes

2008 Introduction: Building Partnerships between Oral History and Memory Studies. In Oral History and Public Memories, Paula Hamilton and Linda Shopes, editors, pp. vii-xvii. Temple University Press, Philadelphia, PA.

Harney Elementary School

2019 About. Harney Elementary School, Vancouver School District, Vancouver, WA <https://harney.vansd.org/about/>. Accessed 12 February 2019.

Hester, Thomas R., Harry J. Shafer, and Kenneth L. Feder 
2009 Field Methods in Archaeology, 7th edition. Left Coast Press, Walnut Creek, CA.

Hodder, Ian

1991 Interpretive Archaeology and its Role. American Antiquity 56(1):4-18.

Hoffman, J.J. and Lester A. Ross

1973a Fort Vancouver Excavations IV: Chief Factor's House and Kitchen. Fort Vancouver National Historic Site, National Park Service, Department of the Interior.

Hoffman, J.J. and Lester A. Ross

1973b Fort Vancouver Excavations V: Flag Staff and Belfry. Fort Vancouver National Historic Site, National Park Service, Department of the Interior.

Hoffman, J.J. and Lester A. Ross

1974a Fort Vancouver Excavations VI: Sales Shop and Powder Magazine. Fort Vancouver National Historic Site, National Park Service, Department of the Interior.

Hoffman, J.J. and Lester A. Ross

1974b Fort Vancouver Excavations VIII: Fur Store. Fort Vancouver National Historic Site, National Park Service, Department of the Interior.

Hollowell, Julie, and Lena Mortensen

2009 Introduction: Ethnographies and Archaeologies. In Ethnographies and Archaeologies: Iterations of the Past, Lena Mortensen and Julie Hollowell, editors, pp. 1-17. University Press of Florida, Gainesville.

Holtorf, Cornelius

2007 Can You Hear Me at the Back? Archaeology, Communication, and Society. European Journal of Archaeology 10(2-3):149-165.

Holtorf, Cornelius

2017 What's Wrong with Cultural Diversity in World Archaeology? Claroscuro 16:1-14.

Hudson, Andrew

2007a Archaeological Predetermination Report: ELMAC, LLC. Report to Washington State Department of Archaeology and Historic Preservation, Olympia from Archaeological Services LLC, Vancouver, WA.

Hudson, Andrew 
2007b State of Washington Archaeological Site Inventory Form: Blue Bird Ridge Site 45CL727. Report to Washington State Department of Archaeology and Historic Preservation, Olympia from Archaeological Services LLC, Vancouver, WA.

Hudson, Andrew and Alexander Gall

2007 Cultural Resources Survey of the Blue Bird Ridge Project Area, Vancouver, Clark County, Washington. Archaeological Services of Clark County. Report to Washington State Department of Archaeology and Historic Preservation, Olympia from Archaeological Services LLC, Vancouver, WA.

Hudson's Bay Company

[1825] Description of the Situation Etc. of the Different Establishments on the Columbia District. Hudson's Bay Company. Manuscript on microfilm, Fort Vancouver National Historic Site, Vancouver, WA.

Hussey, John A.

1957 The History of Fort Vancouver and its Physical Structure. Abbot, Kerns, and Bell Company, Portland, OR.

Jameson, John H. and Sherene Baugher

2008 Public Interpretation, Outreach, and Partnering: An Introduction. In Past Meets Present: Archaeologists Partnering with Museum Curators, Teachers, and Community Groups, John H. Jameson and Sherene Baugher, editors, pp. 3-17. Springer, New York, NY.

Jeppson, Patricia L and George Brauer

2003 Hey, Did You Hear about the Teacher Who Took the Class Out to Dig a Site? Some Common Misconceptions about Archaeology in Schools. In Archaeologists and Local Communities: Partners in Exploring the Past, Linda Derry and Maureen Malloy, editors, pp. 77-96. Society for American Archaeology, Washington, D.C.

Kehoe, Alice Beck

2012 Public Education in Archaeology in North America. In The Oxford Handbook of Public Archaeology, Robin Skeates, Carol McDavid, and John Carman, editors, pp. 537-551. Oxford University Press, Oxford, England.

Kelly, Robert

2003 Forward. In Archaeologists and Local Communities: Partners in Exploring the Past, Linda Derry and Maureen Malloy, editors, pp. vii-viii. Society for American Archaeology, Washington, D.C.

Klimko, Olga 
2004 Fur Trade Archaeology in Western Canada: Who is Digging up the Forts? In The Archaeology of Contact in Settler Societies, Tim Murray, editor, pp. 158175. Cambridge University Press, Cambridge, England.

Lassiter, Luke Eric

2008 Moving Past Public Anthropology and Doing Collaborative Research. NAPA Bulletin 29:70-86.

Lavender, David

1958 Land of Giants: The Drive to the Pacific Northwest 1750-1950. Doubleday and Company, Garden City, NY.

Lavender, David

1981 Fort Vancouver and the Pacific Northwest. In Fort Vancouver National Historic Site Handbook 113. Division of Publications, National Park Service, Washington, D.C.

LeCompte, Margaret D. and Jean J. Schensul

2010 Designing and Conducting Ethnographic Research: An Introduction, 2nd edition. AltaMira Press, Lanham, MD.

Little, Barbara J. (editor)

2002a Public Benefits of Archaeology. University of Florida Press, Gainesville.

Little, Barbara J.

2002b Archaeology as a Shared Vision. In Public Benefits of Archaeology, Barbara J. Little, editor, pp. 3-19. University of Florida Press, Gainesville.

Little, Barbara J.

2007a Archaeology and Civic Engagement. In Archaeology as a Tool of Civic Engagement, Barbara J. Little and Paul A. Shackel, editors, pp. 1-22. Altamira Press, Lanham, MD.

Little, Barbara J.

2007b What are We Learning? Who are We Serving? Publicly Funded Historical Archaeology and Public Scholarship. Historical Archaeology 41(2):72-79.

Little, Barbara J.

2007c Historical Archaeology: Why the Past Matters. Left Coast Press, Walnut Grove, CA.

Little, Barbara J. and Paul A. Shackel (editors)

2007 Archaeology as a Tool of Civic Engagement. Altamira Press, Lanham, MD. 
Low, Setha M. and Irwin Altman

1992 Place Attachment: A Conceptual Theory. In Place Attachment, Irwin Altman and Setha Low, editors, pp. 1-12. Plenum Press, New York, NY.

Malloy, Maureen

2003 Introduction. In Archaeologists and Local Communities: Partners in Exploring the Past, Linda Derry and Maureen Malloy, editors, pp. ix-xiii. Society for American Archaeology, Washington, D.C.

Mariners Museum

2019 HMS Modeste, Stuck in the Columbia River, January 26, 1847. Mariners Museum, Newport News, VA <https://catalogs.marinersmuseum.org/object/CL6440>. Accessed 10 December 2019.

Matsuda, Akira

2016 A Consideration of Public Archaeology Theories. Public Archaeology 15:1-10.

Matsuda, Akira and Katsuyuki Okamura

2011 New Perspectives in Global Public Archaeology. In New Perspectives in Global Archaeology, Katsyuki Okamura and Akira Matsuda, editors, pp. 1-18. Springer, New York, NY.

McClanahan, Angela

2006 Histories, Identity, and Ownership: An Ethnographic Case Study in Archaeological Heritage Management in the Orkney Islands. In Ethnographies of Archaeological Practice: Cultural Encounters, Material Transformations, Matt Edgeworth, editor, pp. 126-136. Altamira Press, Lanham, MD.

McDavid, Carol

2007 Beyond Strategy and Good Intentions: Archaeology, Race, and White Privilege. In Archaeology as a Tool of Civic Engagement, Barbara J. Little and Paul A. Shackel, editors, pp. 67-88. Altamira Press, Lanham, MD.

McGee, Dale A

1972 Soil Survey of Clark County, Washington. United States Department of Agriculture.

<https://www.nrcs.usda.gov/Internet/FSE_MANUSCRIPTS/washington/WA0 11/0/wa011_text.pdf >. Accessed 12 October 2016.

McGuill, Dru

2010 The Public's Archaeology: Utilizing Ethnographic Methods to Link Public Education with Accountability in Archaeological Practice. Archaeologies: Journal of the World Archaeology Congress 6(3):468-484. 
Meany, Edward S.

1925 Vancouver's Centennial. Washington Historical Quarterly 15-16:110-113.

Merk, Frederick (editor)

1968 Fur Trade and Empire: George Simpson's Journal. The Belknap Press of Harvard University Press, Cambridge, MA.

Merriman, Nick

2004a Diversity and Dissonance in Public Archaeology. In Public Archaeology, Nick Merriman, editor, pp. 1-18. Routledge, London, England.

Merriman, Nick (editor)

2004b Public Archaeology. Routledge, London, England.

Meskell, Lynn

2009 Commentary: Cosmopolitan Heritages and the Politics of Protection. In Ethnographies and Archaeologies: Iterations of the Past, Lena Mortensen and Julie Hollowell, editors, pp. 21-29. University Press of Florida, Gainesville.

Mize, Jeffrey

2019a Searching for First Fort Vancouver. The Columbian 26 March: C1, C3. Vancouver, WA.

Mize, Jeffrey

2019b Was First Fort Vancouver Built in Edgewood Park Neighborhood? The Columbian 27 March: A1-A2. Vancouver, WA.

Mize, Jeffrey

2019c Researcher Offers Clues about First Fort Vancouver. Lewiston Tribune 29 March. <https://lmtribune.com/northwest/researcher-offers-clues-about-firstfort-vancouver/article_23e565f4-c783-5830-935a-ed24bd1ced6d.html>. Accessed 3 February 2020.

Moe, Jeanne M.

2002 Project Archaeology: Putting the Intrigue of the Past in Public Education. In Public Benefits of Archaeology, Barbara J. Little, editor, pp. 176-186. University Press of Florida, Gainesville.

Montell, William Lynwood, and Barbara Allen Bogart (editors)

1981 From Memory to History: Using Oral Sources in Local Historical Research. American Association for State and Local History, Nashville.

Morgan, Colleen, and Judith Winters 
2015 Introduction: Critical Blogging in Archaeology. Internet Archaeology (39) <http://intarch.ac.uk/journal/issue39/editorial.html>. Accessed 12 October 2019.

Morrison, Dorothy Nafus

2004 Outpost: John McLoughlin and the Far Northwest. Oregon Historical Society Press, Portland.

Moser, Stephanie, Darren Glazier, James E. Phillips, Lamya Nasser El Nemr, Mohammad Mousa, Rascha Nasr Aiesh, Susan Richardson, Andrew Conner, and Michael Seymour

2002 Transforming Archaeology through Practice: Strategies for Collaborative Archaeology and the Community Archaeology Project at Quseir, Egypt. World Archaeology 32(2):220-248.

Moshenka, Gabriel

2007 Oral History in Historical Archaeology: Excavating Sites of Memory. Oral History 35(1):91-97.

Mrozowski, Stephen A.

2012 Pragmatism and the Relevancy of Archaeology for Contemporary Society. In Archaeology in Society: Its Relevance in the Modern World, Marcy Rockman and Joe Flatman, editors, pp. 239-256. Springer, New York, NY.

Nassaney, Michael S.

2015 The Archaeology of the North American Fur Trade. University Press of Florida, Gainesville.

National Park Service

2014 Vision Paper: 21st Century National Park Service Interpreter Skills. National Park Service <https://mylearning.nps.gov/wpcontent/uploads/2016/05/Interpretive-Skill-Vision-Paper_FINAL-reduced-filesize.pdf $>$. Accessed 9 January 2020.

National Park Service

2017 Kaiser Shipyards Exhibit Opens at Pearson Air Museum, National Park Service <https://www.nps.gov/fova/learn/news/kaisershipyardsexhibit.htm>. Accessed 7 October 2019.

National Park Service

2016 Fort George Research Inventory and Assessment. National Park Service <https://www.nps.gov/lewi/learn/historyculture/fort-astoria-fort-george.htm.>. Accessed 18 November 2016. 
Pape, Janet L.

2008 Archaeology Outreach: It Takes a Community. In Past Meets Present: Archaeologists Partnering with Museum Curators, Teachers, and Community Groups, John H. Jameson, Jr. and Sherene Baugher, editors, pp. 379-392. Springer, New York, NY.

Perry, Sara

2015 Changing the Way Archaeologists Work: Blogging and the Development of Expertise. Internet Archaeology (39).

<https://intarch.ac.uk/journal/issue39/9/toc.html>. Accessed 12 October 2019.

Pettigrew, Richard M.

1981 A Prehistoric Culture Sequence in the Portland Basin of the Lower Columbia Valley. University of Oregon Anthropological Papers No. 22.

Plumer, Martin

2018 How Can Community Engagement in the Local Past and Archaeological Research be Mutually Beneficial? A Case Study in Community Archaeology from Sauvie Island, Oregon. Master's Thesis, Department of Anthropology, Portland State University. PDX Scholar, Portland, OR.

Praetzellis, Mary, Adrian Praetzellis, and Thad Van Buren.

2007 Remaking Connections: Archaeology and Community after the Loma Prieta Earthquake. In Archaeology as a Tool of Civic Engagement, Barbara J. Little and Paul A. Shackel, editors, pp. 109-130. Altamira Press, Lanham, MD.

Pyburn, K. Anne

2003 Archaeology for a New Millennium: The Rules of Engagement. In Archaeologists and Local Communities: Partners in Exploring the Past, Linda Derry and Maureen Malloy, editors, pp. 167-184. Society for American Archaeology, Washington, D.C.

Richardson, Lorna Jane and Jaime Almansa-Sánchez

2015 Do You Even Know What Public Archaeology is? Trends, Theory, Practice, Ethics. World Archaeology 47(2):194-211.

Robbins, William G.

1997 Landscapes of Promise: The Oregon Story 1800-1940. University of Washington Press, Seattle.

Robbins, Christine Reiser and Mark W. Robbins

2014 Engaging the Contested Memory of the Public Square. Community Collaboration, Archaeology, and Oral History at Corpus Christi's Artesian Park. The Public Historian 36(2):26-50. 
Rockman, Marcy and Joe Flatman (editors)

2012 Archaeology in Society: Its Relevance in the Modern World. Springer, New York, NY.

Ronda, James P.

1990 Astoria and Empire. University of Nebraska Press, Lincoln.

Rosenzwieg, Roy and David Thelen

1998 The Presence of the Past: Popular Uses of History in American Life. Columbia University Press, New York, NY.

Sage, Walter N.

1948 The Place of Fort Vancouver in the Pacific Northwest. The Pacific Northwest Quarterly 39:(2):83-102.

Schaepe, David M., Bill Angelbeck, David Snook, and John R. Welch.

2017 Archaeology as Therapy: Connecting to Belongings, Knowledge, Time, Space, and Well-Being. Current Anthropology 58(4):502-533.

Schensul, Jean J. and Margaret D. LeCompte

2013 Essential Ethnographic Methods: A Mixed Methods Approach, 2nd edition. AltaMira Press, Lanham, MD.

Scouler, John

1905 Dr. John Scouler's Journal of a Voyage to N.W. America [1824-'25-'26] II. Leaving the Galapagos Islands for the North Pacific Coast. The Quarterly of the Oregon Historical Society 6(2):159-205.

Shackel, Paul A.

2004 Working with Communities: Heritage Development and Applied Archaeology. In Places in Mind: Public Archaeology as Applied Anthropology, Paul A. Shackel and Erve J. Chambers, editors, pp. 1-16. Routledge, New York, NY.

Shackel, Paul A. and Erve J. Chambers (editors)

2004 Places in Mind: Public Archaeology as Applied Anthropology. Routledge, New York, NY.

Shine, Gregory P.

2019 William Selby Harney (1800-1889). Oregon Encyclopedia, Portland $<$ https://oregonencyclopedia.org/articles/harney_william_selby/\#.XZucHEZKj IU>. Accessed 7 October 2019.

Skeates, Robin, Carol McDavid, and John Carman (editors) 
2012 The Oxford Handbook of Public Archaeology. Oxford University Press, Oxford, England.

Society for American Archaeology

1996 Principals of Archaeological Ethics. Society for American Archaeology, Washington, D.C. <https://www.saa.org/career-practice/ethics-in-professionalarchaeology $>$. Accessed 18 February 2019.

Society for American Archaeology

2018 American Perceptions of Archaeology. Society for American Archaeology, Washington, D.C. <https://www.saa.org/education-outreach/publicoutreach/public-perceptions-studies >. Accessed 13 February 2020.

Society for Historical Archaeology

2018 Historic Glass Bottle Identification and Information Website. Society for Historical Archaeology, Germantown, MD <https://sha.org/bottle/index.htm>. Accessed 19 August 2018.

Soderland, Hilary A.

2012 America's Cherished Reserves: The Enduring Significance of the 1916 National Park Organic Act. In The Oxford Handbook of Public Archaeology, Robin Skeates, Carol McDavid, and John Carman, editors. Oxford University Press, Oxford, England.

Spoon, Jeremy

2014 Quantitative, Qualitative, and Collaborative Methods: Approaching Indigenous Ecological Knowledge Heterogeneity. Ecology and Society 19(3):33.

Stottman, M. Jay (editor)

2010 Archaeologists as Activists: Can Archaeologists Save the World? University of Alabama Press, Tuscaloosa.

Taber, Emily Celene

2018 Using Archival and Archaeofaunal Record to Examine Victorian-era Fish Use in the Pacific Northwest. Master's Thesis, Department of Anthropology, Portland State University. PDX Scholar, Portland, OR.

Taylor, Terri A.

1992 Cultural Landscape Report: Fort Vancouver National Historic Site, Volume 1. National Park Service, Department of the Interior, Cultural Resources Division, Pacific Northwest Region, Seattle, WA.

Thomas, Bryn and Linda Freidenburg 
1998 A Review of Data Pertaining to Cemeteries, Human Remains, Burials, and Grave Markers Associated with Fort Vancouver and Vancouver Barracks, Clark County, Washington. Report to National Park Service, Seattle, WA and Washington State Department of Archaeology and Historic Preservation, Olympia.

Thomas, Bryn and Charles Hibbs, Jr.

1984 Report of Investigations at Kanaka Village Vancouver, Barracks, Washington 1980/1981. Report to Washington State Department of Transportation from Archaeological and Historical Services, Eastern Washington University.

Thomas, Roger M.

2004 Archaeology and Authority in the Twenty-First Century. In Public Archaeology, Nick Merriman, editor, pp. 191-201. Routledge, London, England.

\section{US Census Bureau}

2018 Quick Facts Vancouver City, Washington.

<www.census.gov/quickfacts/vancouvercitywashington>. Accessed 2 December 2019.

Uunila, Kirsti

2003 Sukeek's Cabin: Archaeology, a Family's Story, and Building Community. In Archaeologists and Local Communities: Partners in Exploring the Past. Linda Derry and Maureen Malloy, editors, pp. 31-43. Society for American Archaeology, Washington, D.C.

\section{Vancouver Columbian}

1935a Grisly Graves in East Vancouver Yield Skeletons: Forgotten Burial Grounds of Pioneers Unearthed Near Gravel Pit. 21 March. Vancouver, WA.

\section{Vancouver Columbian}

1935b Third Skeleton Unearthed Here. 25 March. Vancouver, WA.

Vogt, Tom

2018 Graduate Student Embarks on Project to Pinpoint Site of Original Fort Vancouver. The Columbian 2 May. Vancouver, Washington. $<$ https://www.columbian.com/news/2018/may/02/graduate-student-embarkson-project-to-pinpoint-site-of-original-fort-vancouver/>. Accessed February 4, 2020.

Washington Department of Archaeology and Historic Preservation 
2019 Archaeology. Washington Department of Archaeology and Historic Preservation, Olympia < https://dahp.wa.gov/archaeology>. Accessed 11 May 2017.

Washington State School for the Deaf

1996 A History of the Washington State School for the Deaf 1886-1996.

Manuscript, Washington State School for the Deaf, Vancouver, WA

Wheeler, Mortimer

1956 Archaeology from the Earth. Penguin Books, Baltimore, MD.

Wilson, Douglas C.

2014 The Decline and Fall of the Hudson's Bay Company Village at Fort Vancouver. In Alis Volit Propiis: Tales from the Oregon Territory, 1848-1859, Chelsea Rose and Mark Axel Tveskov, editors. Association of Oregon Archaeologists Occasional Paper Series No. 9, Eugene, Oregon.

Wilson, Douglas C., Robert Cromwell, Danielle Gembala, Theresa Langford, Heidi Pierson, and Debra Semrau

2011 Archaeology Lab Manual, 3rd Edition. Manuscript, Fort Vancouver National Historic Site, Vancouver, WA.

Wilson, Douglas C. and Theresa E. Langford (editors)

2011 Exploring Fort Vancouver. University of Washington Press, Seattle.

Wright, Alice

2015 Private Property, Public Archaeology: Resident Communities as Stakeholders in American Archaeology. World Archaeology 47(2):212-224.

Yow, Valerie Raleigh

2005 Recording Oral History: A Guide for the Humanities and Social Sciences, 2nd edition. Altamira Press, Lanham, MD. 
Appendices 


\section{Appendix A: Additional Historical Background}

\section{The North American Fur Trade}

The fur trade was a global industry for centuries, with traders sailing around the world buying and selling furs and other goods. The North American fur trade was crucial in determining much of the way North America appears today, and its legacy is reflected throughout North America in the form of cities, towns, and roadways that were initially established during this period (Hyde 2011:477). However, Europeans landing in North America did not invent the fur trade here; indeed, upon arrival they found an already robust network of trade linking regions across the continent. Long before Europeans settled in North America, American Indians had in place complex systems for trading with groups far and wide, and were adept at hunting, trapping, and processing animals for food and furs. Thousands of years ago native North Americans started exploiting animals for their furs and skins, and, beginning in the sixteenth-century, contact and trade with nations from other continents, many of which were European, spurred intensified exploitation of animals for their furs (Nassaney 2015).

During the reign of Charles I in Great Britain (1625-1649) large felt hats came into vogue creating a heavy demand for furs in Europe (Hudson's Bay Company 1955:3). After decimating its own supply of desirable animals through centuries of overexploitation, the lucrative European fur trade saw immeasurable opportunity in fur-rich North America (Dolin 2010:11), with mainly the French and the British competing for access to North American land for fur trapping and contact with Native Americans for trading (Dolin 2010:107). Many animals were targeted for their pelts, but beaver fur became the prize of the North American fur trade because it is spiccated, or barbed, making it ideal for felting into material for clothing and hats (Hudson's Bay Company 1955:3)

When Europeans first became involved in the North American fur trade business, American Indians had control over trade and supplied Europeans with furs within the existing framework of trade (Nassaney 2015:40). Later, while still depending on Native peoples to obtain and process furs, Europeans moved away from the coast to interior 
lands and, as they came into direct contact with the fur sources, they took control of the procurement and transportation of goods (Nassaney 2015:40). Once American Indians were no longer needed as the main suppliers, the road was paved for organized furtrading companies to take over the land, and trading posts like Fort Vancouver were established along waterways, the most efficient mode of travel and transport of the time.

By the late 18th and early 19th centuries, several European and American fur trade companies occupied and competed in North America, such as the American Fur Company, the Pacific Fur Company, the North West Company, and the Hudson's Bay Company. These companies constructed forts across the continent to serve as operations bases and trading posts, usually near Native American villages and along traditional travel routes. Fur traders understood that the fur trade could not survive without the cooperation of Native groups (Nassaney 2015:16). The British overtook the French in the North American fur trade in the mid-18th century, and as the trade continued into the 19th century Britain ruled the exploitation of America's seemingly limitless supply of economically-valuable animals (Dolin 2010:116).

\section{The Hudson's Bay Company}

In the 19th century, the Hudson's Bay Company (HBC) rose to dominate the North American fur trade. The HBC was chartered in 1670 in England during the reign of Charles II (Hudson's Bay Company 1955:8). HBC forts in North America cropped up almost immediately with four having been built by 1685 in the vicinity of Hudson's Bay (Hudson's Bay Company 1955:9). Until 1713, the HBC enjoyed peaceful years of trapping and trading with punctuations of violent outbreaks between rivaling companies (Hudson's Bay Company 1955:10) and with area Native groups (Hudson's Bay Company 1955:13). In the mid- $18^{\text {th }}$ century, the HBC began moving inland to the west (Hudson's Bay Company 1955:15), competing aggressively with a grouping of nine fur partners called the North West Company (Hudson's Bay Company 1955:18). After decades of fighting the two companies merged in 1821, retaining the title of Hudson's Bay Company, and creating a monopoly across the continent (Hudson's Bay Company 1955:21). This larger Company divided its North American interests into four departments (Hudson's Bay Company 1955:22): The Northern Department of Rupert's 
Land, the Southern Department, the Montreal Department, and the Columbia Department in which Fort Vancouver was established.

\section{References}

Dolin, Eric Jay

2010 Fur, Fortune, and Empire. W.W. Norton and Company, New York and London.

Hudson's Bay Company

[1955] A Brief History of the Hudson's Bay Company. Hudson's Bay Company, Winnipeg.

Hyde, Anne F.

2011 Empires, Nations, and Families: A History of the North American West, 18001860. University of Nebraska Press, Lincoln and London.

Nassaney, Michael S.

2015 The Archaeology of the North American Fur Trade. University Press of Florida: Gainesville. 


\section{Appendix B: IRB approval letters}

\section{SP Portland State}

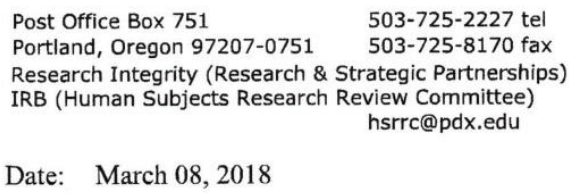

Date: $\quad$ March 08, 2018

To: $\quad$ Douglas Wilson / Amy Clearman, Anthropology

From: Lindsey Wilkinson, IRB Chair

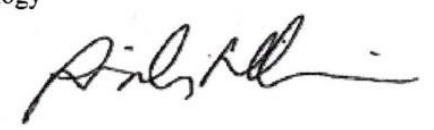

Re: $\quad$ IRB approval for your protocol \# 184543, entitled: "Search for the First (1825-1829) Fort Vancouver."

Approval-Expiration: March 08, 2018-March 07, 2019

\section{Notice of IRB Review and Approval - Initial Review Expedited Review Categories 6, 7; as per Title 45 CFR Part 46}

In accordance with your request, the PSU Institutional Review Board (Human Subjects Research Review Committee) has reviewed and approved the project referenced above for compliance with PSU policies and DHHS regulations covering the protection of human subjects. The IRB is satisfied that your provisions for protecting the rights and welfare of all subjects participating in the research are adequate. Please note the following requirements:

Approval: You are approved to conduct this research study only during the period of approval cited above, and the research must be conducted according to the plans and protocol submitted (approved copy enclosed).

Consent: You must use IRB-approved consent materials with study participants.

Changes to Protocol: Any changes in the proposed study, whether to procedures, survey instruments, consent forms or cover letters, must be outlined and submitted to the IRB immediately. The proposed changes cannot be implemented before they have been reviewed and approved by the IRB.

Continuing Review: This approval will expire on 03/07/2019. It is the investigator's responsibility to ensure that a Continuing Review Report is submitted to the IRB two months before the expiration date, and that approval of the study is kept current. The Continuing Review Report is available on the Research Integrity website.

Adverse Reactions and/or Unanticipated Problems: If any adverse reactions or unanticipated problems occur as a result of this study, you are required to notify the Research Integrity within 5 days of the event. If the issue is serious, approval may be withdrawn pending an investigation by the IRB.

Completion of Study: Please notify the IRB as soon as your research has been completed. Study records, including protocols and signed consent forms for each participant, must be kept by the investigator in a secure location for three years following completion of the study (or per any requirements specified by the project's funding agency).

If you have questions or concerns, please contact the Research Integrity office in Research \& Strategic Partnerships at hsrrc@pdx.edu or (503) 725-2227. 


\section{Human Research Protection Program Notice of Continuing IRB Approval}

March 12, 2019

Dear Investigator:

The PSU Institutional Review Board (IRB) reviewed the following continuing review submission:

\begin{tabular}{|l|l|}
\hline Investigator(s) & Douglas Wilson / Amy Clearman \\
\hline HRPP \# & 184543 \\
Title & Search for the First (1825-1829) Fort Vancouver \\
Funding Agency / Kuali \# & N/A \\
IRB Approval Date & $03 / 12 / 2019$ \\
Expiration Date & $03 / 07 / 2020$ \\
\hline Review Category(ies) & Expedited: \# 6, 7 \\
\hline
\end{tabular}

The IRB determined the continuation request satisfies the required provisions for protecting the rights and welfare of all subjects participating in research. This study approval has been renewed and must be conducted in accordance with the protocol submitted (HRPP Forms enclosed). Please note the following ongoing Human Research Protection Program (HRPP) requirements:

Consent: IRB-approved consent materials must be used with subjects.

Changes to Study Activities: Any changes to the study must be submitted to ORI for review and determination prior to implementation.

Unanticipated Problems or Adverse Events: Notify ORI within 5 days of any unanticipated problems or adverse events that occur as a result of the study.

Continuing Review: The IRB determined this project requires Continuing Review. To request study renewal, a Continuation request must be submitted prior to expiration.

Study Completion: Notify ORI when the research is complete; ORI will request annual updates on the study status. HRPP-related materials must be kept for at least three years following study completion.

Compliance: The PSU IRB (FWA00000091; IRB00000903) and the ORI comply with 45 CFR Part 46, 21 CFR Parts 50 and 56, and other federal and Oregon laws and regulations, as applicable.

If there are any questions, please contact the ORI at psuirb@pdx.edu or call 503-725-5484.

Sincerely,

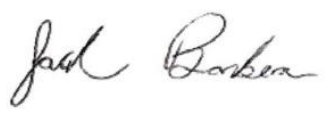

Jack Barbera, IRB Chair 
March 02, 2020

\section{Human Research Protection Program Notice of Continuing IRB Approval}

Desr investigator,

The PSU Institutional Review Board (IRB) reviewed the following continuing review submission:

\begin{tabular}{|l|l|}
\hline Investigator(s) & Douglas Wilson / Amy Clesrman \\
\hline HRPP $\approx$ & 184543 \\
\hline Title & Sesrch for the First (1825-1829) Fort Vancouver \\
\hline Funding Agency / Kusli $\approx$ & $\mathrm{N} / \mathrm{A}$ \\
\hline Expiration Date & $03 / 07 / 2021$ \\
\hline Review Category[ies) & Expedited: $\# 8(\mathrm{c})$ \\
\hline
\end{tabular}

The IRB determined the continuation request sstisfies the required provisions for protecting the rights snd welfore of all subjects participating in resesrch. This study approval has been renewed snd must be conducted in accordance with the protocol submitted (HRPP Forms enclosed). Plesse note the following ongoing Human Research Protection Program (HRPP) requirements:

Changes to Study Activities: Any changes to the study must be submitted to the HRPP for review and determinstion prior to implementstion.

Unanticipated Problems or Adverse Events: Notify the HRPP within 5 days of sny unanticipated problems or adverse events that occur as a result of the study.

Continuing Review: Studies that are over 5 yesrs old, snd 1) still collecting dsts from subjects, or 2) performing identifiable-dsta analyzis must be re-reviewed under the new federal regulations and do not qualify for continuing review. Submit a new protocol under the Revised Common Rule requirements, using the forms on our waspite. If this study qualifies for Continuing Review, a Continuation request must be submitted prior to expiration.

Study Closure: This study may be closed when there is no longer contact with subjects and all anslysis with identifiable data is complete. Identifiable data may be maintained $\mathrm{as}$ long as analyais is complete. If you wish to utilize the identifisble data in the future a new study submission is required.

Compliance: The PSU IRB (FWA00000091; IRB00000903) and the HRPP comply with 45 CFR Part 46, 21 CFR Parts 50 and 56 , and other federal and Oregon laws and regulations, as applicable. HRPp-relsted materials must be kept for at lesst three years following study completion.

If there are any questions, please contact the HRPP at psuirb 9 pdx.edu or call 503-725-5484.

sincerely.

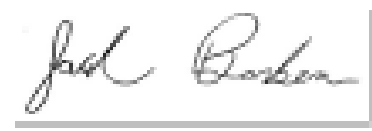

Jack Barbera, IRB Chair 


\section{Appendix C: Recruitment letter to Edgewood Park homeowners}

October 16, 2018

Dear resident,

Hello! My name is Amy Clearman. I am a graduate student at Portland State University and I am doing my Master's thesis project in your neighborhood! You may have read about my project in The Columbian newspaper, saw flyers around Fort Vancouver, or even attended my presentation back in May.

Since you are a resident in my project area, I would be so excited to work with you! I have collaborated with several of your neighbors already through interviews and archaeological excavation. I am working with residents to try to find archaeological evidence of the first Fort Vancouver built in 1825 somewhere in your neighborhood. Even though a sign at the Washington State School for the Deaf indicates the fort was at that campus, no archaeological research has ever confirmed the fort's exact location. So, I have been excavating small holes in residents' yards to search for clues to where the first fort may have been. I would like to reassure you that finding archaeological remains does not mean that the government can take away private property from property owners. Even in the unlikely event that an archaeological site is found, the government cannot take away your property. What would happen is that you would possibly need to obtain a permit from the state before doing any ground-disturbing activities, like new building construction or tree removal for example. But, because of the area you live in, you likely have to get these permits already. I would also like to reassure you that I am not proposing large-scale excavation, but simply one or two round holes measuring a little over a foot wide each. So, the impact to your property is extremely small and when I am done it will be hard to tell there was even any digging done.

Also, I am conducting an ethnographic study to find out views and attitudes of residents toward their neighborhood. This involves a one-hour interview where I would ask you questions about your neighborhood, neighborhood heritage, and archaeology.

Participants' identities will remain confidential. I will use data I collect from excavation and interviews for my thesis paper, but I will not make participants' identities and property locations known to anyone else whatsoever.

I would really appreciate your input in this project! You can choose to participate in both the interview and archaeological portions, or just the interview or just the archaeological excavation. It's up to you and what you feel most comfortable with.

Please contact me if you have even the slightest interest in participating. We can talk in person, by phone, or by email and I can address any questions or concerns you may have. You can also visit my blog to find out more: www.FirstFortVancouver.com. 
I look forward to hearing from you soon!

Contact me!

Amy Clearman

Department of Anthropology

Portland State University

503-XXX-XXXX

FirstFortVancouver.com 


\section{Appendix D: Recruitment letter to Edgewood Park renters}

September 7, 2018

Dear resident,

Hi, my name is Amy Clearman and I am a graduate student at Portland State University. I am doing my Master's thesis project in your neighborhood! It is possible that you read about my project in the Columbian newspaper, saw flyers around Fort Vancouver, or even attended my presentation back in May. Since you are a renter in the project area, I am very much interested in talking with you.

My project has two main parts. First, I am working with residents to try to find archaeological evidence of the first Fort Vancouver built in 1825 somewhere in your neighborhood. Even though a sign at the Washington State School for the Deaf indicates the fort was at that campus, no archaeological research has ever confirmed the fort's exact location. So, I have been excavating small holes in residents' yards to search for clues to where the first fort may have been. Since you are a renter, I will not be able to excavate at your residence, but would be so happy to have you participate in the second aspect of the project.

For the second part, I am doing an ethnographic study of the neighborhood in which I am interviewing residents about the neighborhood. The interview is about one hour long and I would ask questions about your neighborhood, neighborhood heritage, and archaeology.

I am seeking out interview participants who are renting apartments or homes in the neighborhood and who have lived in the neighborhood for a really short amount of time, even just one month, up to a really long amount of time. Your time involved in my project will be very short, but it will give me a huge amount of information to address my research questions.

Please contact me if you have even the slightest interest in participating. We can talk in person, by phone, or by email and I can address any questions or concerns you may have. You can also visit my blog to find out more: www.FirstFortVancouver.com.

I look forward to hearing from you soon!

Contact me!

503-XXX-XXXX

Amy Clearman

Anthropology Department

Portland State University

Graduate Research Assistant

Fort Vancouver National Historic Site 


\section{Appendix E: Survey 1 questions}

1. Age (Circle one): 18-29 30-49 50-69 70+

2. Do you live in Vancouver, Washington? (Circle one) Yes No

If yes, do you live in either the Hudson's Bay Neighborhood or the Edgewood Park Neighborhood? (Circle one): Yes No

3. Have you ever visited Fort Vancouver National Historic Site? (Circle one): Yes No

4. Did you ever hear about the first Fort Vancouver before this meeting? (Circle one): Yes No

5. What comes to mind when you think of "heritage"? (List approximately 3 words or phrases):

6. What comes to mind when you think of "archaeology"? (Write sentences, phrases, or key words):

7. Have you ever visited an archaeological site? (Circle one): Yes No

8. What are some ways you have ever learned about archaeology? (For example: books, magazines, tv, websites, visiting a dig, etc.)

9. Do you think archaeology is important to your life personally? (Circle one): Yes No

If yes, in what ways?

If no, why not?

10. Do you think archaeology is important to society as a whole? (Circle one): Yes No

If yes, in what ways?

If no, why not?

11. Do you think heritage is important in the community where you live? (Circle one): Yes No

If yes, in what ways?

If no, why not? 


\section{Appendix F: Survey 2 questions}

1. Age (Circle one): 18-29 30-49 50-69 70+

2. Do you live in Vancouver, Washington? (Circle one): Yes No

If yes, do you live in either the Hudson's Bay Neighborhood or the Edgewood Park Neighborhood? (Circle one): Yes No

3. Have you ever visited Fort Vancouver National Historic Site? (Circle one): Yes No

4. Did you ever hear about the first Fort Vancouver before this meeting? (Circle one): Yes No

5. What comes to mind when you think of "heritage"? (List approximately 3 words or phrases):

6. What comes to mind when you think of "archaeology"? (Write sentences, phrases, or key words):

7. Have you ever visited an archaeological site? (Circle one): Yes No

8. What are some ways you have ever learned about archaeology? (For example: books, magazines, tv, websites, visiting a dig, etc.)

9. Do you think archaeology is important to your life personally? (Circle one): Yes No

If yes, in what ways?

If no, why not?

10. Do you think archaeology is important to society as a whole? (Circle one): Yes No

If yes, in what ways?

If no, why not?

11. Did you know about the project discussed at this meeting before today? (Circle one): Yes No

12. Did anything about this project change how you feel about heritage and/or archaeology? (Circle one): Yes No

If yes, in what ways?

If no, why not? 


\section{Appendix G: Survey informed consent}

Hello! Thank you for taking time to complete this short survey. It should take about 10 minutes to complete. This anonymous questionnaire will be used as a portion of a thesis research project I am conducting as part of my Master's degree requirements at Portland State University. For my graduate thesis project, I am exploring evidence of the remains of the first Fort Vancouver. This questionnaire will help me understand how community members feel about heritage and archaeology. Information from this questionnaire will be used as data for my thesis project and will be published in a thesis research document. The questionnaire is anonymous, and you will receive no penalty or reward for choosing to participate or not. Participation is voluntary and you may choose to refuse to answer any questions. By filling out the questionnaire you are agreeing to anonymously participate in this research. Thank you! I appreciate your contribution to my project! 


\section{Appendix H: Interview informed consent}

Hello! You are being asked to be interviewed for a project that is being done by Amy Clearman, a graduate student in the Anthropology department at Portland State University. This project is a collaboration with Vancouver neighborhood residents in archaeological and ethnographic research to potentially locate the first (1825) Fort Vancouver.

You are being asked to participate in this project because you are a resident in a neighborhood of interest.

This form will explain the research project. If you have any questions before taking part in the project please ask me.

Participation in this project will take about one hour for the interview (in the summer of 2018), plus about half an hour at the end of the project (likely in August or September of 2018) for a follow-up interview. I will ask you questions about your neighborhood, anything you know about neighborhood history, your thoughts and feelings about your neighborhood, and your views on neighborhood heritage. I will ask you how you feel about archaeology, especially about archaeological sites in your neighborhood, and about having Fort Vancouver National Historic Site so near your home. During the follow-up interview you will have the opportunity to add any information that you did not share during the first interview.

This interview will be used as part of a thesis research project I am conducting as part of my Master's degree requirements at Portland State University. For my graduate thesis project, I am exploring evidence of the remains of the first Fort Vancouver. Interviews conducted for this project will help me understand how residents feel about heritage and archaeology in their neighborhood and may also help identify potential artifacts related to the first Fort Vancouver and its possible location.

Information from this interview will be used as data for my thesis project and will be published as a thesis research document. Any information used from your interview will be anonymous, unless you give express permission for me to cite quotes from you.

Information derived from the interview may lead me to ask to either look at artifact collections you may have from your property, or to archaeologically excavate on your property. Your participation in showing me artifacts or allowing excavation is completely voluntary.

If archaeological excavation were to lead to identification of the first Fort Vancouver on your property, registering it as an archaeological site with the Washington State Department of Archaeology and Historic Preservation (DAHP) is required. The location of an archaeological site on your property does not mean anyone can take away your 
property or limit what you can do on your property. It would simply require additional permits for any ground-disturbing activities, such as construction projects or tree removal.

Also, if archaeological excavation were to lead to identification of the first Fort Vancouver on your property you would have the voluntary choice to register the site as an historic place with the National Register of Historic Places, the Washington Heritage Register, and/or the Clark County Heritage Register. Registration may affect property value and property tax assessment, although it most often results in increased property value and reduced property taxes for a period of time.

In the event that the decision is made to register with DAHP or the historic registers, I will offer assistance and provide information about how to proceed with the process.

This interview will be audio recorded and transcribed. All recorded and transcribed information collected in the project will be accessible only to me and to my advisor, Dr. Douglas Wilson. You will receive a copy of the transcription and the recorded interview.

I may ask to photograph you to include with the transcription document. You may refuse to be photographed with no penalty. Please initial:

Yes, I agree to be photographed

No, I do not agree to be photographed

Your participation in the project is completely voluntary. You have the right to choose not to participate or to withdraw your participation at any point in this project. You can also refuse to answer any question that I ask. Refusal to participate or to discontinue participation will involve no penalty or loss of benefits.

If you have any questions or complaints about this project I will be glad to answer them at 503-XXX-XXXX or clearman@pdx.edu. You may also contact PSU's Office of Research Integrity at hsrrc@pdx.edu or 503-725-2227 with any questions or complaints.

If you agree to be interviewed and recorded as part of this study please sign below. You will be provided a copy of this consent form for your records.

I am grateful for your valuable time and cooperation!

Date

Printed Name of Participant

Signature of Participant 


\section{Appendix I: Informational interview questions}

- Identifying questions:

Name, occupation, age, neighborhood of residence

- What year did you move to Vancouver?

- Do you currently live in the Hudson's Bay or Edgewood Park neighborhood?

- If not, when did you live in one of these neighborhoods?

- Did you have family members who lived in Vancouver before you?

- Tell me your earliest memories about the project area.

- What do you know about the history of the project area?

- How has the project area changed over time?

- What do you know about the first Fort Vancouver?

- Tell me about any artifacts that you or your family have discovered on your property.

- What about artifacts your neighbors may have found?

- Did you ever hear stories about the pioneer graves that were discovered in the area?

- Do you have any artifacts or photos you would like to show me? 


\section{Appendix J: Ethnographic interview questions}

\section{Personal}

- Identifying questions:

Name, occupation, age, neighborhood of residence, address of interest

- What year did you move to Vancouver?

- What parts of Vancouver have you lived in?

- If you do not live in Hudson's Bay or Edgewood Park neighborhood now, did you ever and when?

- How long have you lived at your present address?

- Did you have family members who lived in one of these two neighborhoods before you?

- Do you know anything about the history of your house and property?

- What are the home improvements/construction projects that have been done to the property that you know of?

- Have you heard anything about the history of your neighbors' properties?

\section{Place Attachment}

- What areas are most important to you in your neighborhood? What makes your neighborhood special?

- How involved would you say you are in your neighborhood, such as going to events, the neighborhood association, etc.?

- Would you say you feel attached to your neighborhood?

- If yes, what makes you feel attached or connected?

\section{Heritage}

- What does 'heritage' mean to you?

- In what ways do you think heritage is important or not important?

- In what ways do you see evidence of heritage in your neighborhood?

- Do you think visible heritage is an asset or detriment to your neighborhood? In what ways?

- Do you think heritage is important to other members of your neighborhood?

- Are there ways you would like to see your neighborhood's heritage emphasized or de-emphasized?

- How would you characterize the level of diversity in your neighborhood? (economic status, ethnicity, mixed uses of neighborhood)

- How do you think this level of diversity affects issues of heritage in the neighborhood?

\section{Archaeology}

- What do you know about archaeology?

- How is your life affected by archaeology?

- Do you think archaeology is important to your neighborhood? How about to society?

- How would you feel about possibly having an archaeological site on your property? 


\section{Second Fort Vancouver}

- How do you feel about sharing your neighborhood with a major archaeological site (Fort Vancouver National Historic Site)?

- What do you think of Fort Vancouver? Why is it important or not important to you?

- How do you feel about tourism and local visitation to Fort Vancouver? (Types of visitors, impact of tourism on the neighborhood, etc.)

\section{First Fort Vancouver}

- Did you know there was a first Fort Vancouver?

- Did you ever hear stories about the first Fort Vancouver?

- How much do you think other residents know about the first Fort Vancouver?

- Have you ever heard about the Catfish ponds off of Grand Blvd by Fred Meyer?

- Tell me about any artifacts that you or your family have discovered on your property.

- What about artifacts your neighbors may have found?

- Did you ever hear stories about the pioneer graves that were discovered in the area in 1925 ?

- Do you have any artifacts or photos related to the history of your neighborhood or property that you would like to show me? 


\section{Appendix K: Follow-up interview questions}

The Project

- What was it like participating in this project?

- Did you feel comfortable with it? Were there parts that made you uncomfortable?

- Did the project meet your expectations?

- Do you think people would have responded differently to the project if I had been a local resident versus a researcher from Portland State?

Neighborhood

- Are there any changes in what is important to you in your neighborhood, or in what makes your neighborhood special?

- Are there changes in how attached you feel to your neighborhood after participating in this project?

Heritage

- Are there changes in how you see evidence of heritage in your neighborhood?

- Are there changes in how you would like to see your neighborhood's heritage emphasized or de-emphasized?

Archaeology

- Do you feel differently about archaeology now? If yes, in what ways?

- Are there changes in how you think of archaeology's importance in your neighborhood? How about in society?

Fort Vancouver

- Did this project change how you feel about Fort Vancouver National Historic Site?

- Have you notices if this project has made other people in the area more aware of the first Fort Vancouver or simply more aware of area history and heritage in general?

Artifacts and history

- Have you encountered any artifacts since I was here last?

- Have you gotten any more information about the history of your house or neighborhood that you would like to share with me?

Any final comments about the project? 


\section{Appendix L: Excavation informed consent}

Hello! You are being asked to take part in a project that is being done by Amy Clearman, a graduate student in the Anthropology department at Portland State University. This project is a collaboration with Vancouver neighborhood residents in archaeological research to potentially locate the first (1825) Fort Vancouver.

You are being asked to participate in this project because your property has been identified as potentially containing materials related to the 1825 Fort Vancouver.

This form will explain the research project. If you have any questions before taking part in the project please ask me.

Participation in this project will involve archaeological excavation on your property. Excavation involves digging into the ground to search for material remains of the 1825 Fort Vancouver. Ground disturbance will be kept to a minimum and will only take place in areas you approve of. There will be no excavation in areas that may be harmful to your property in any way.

Information from archaeological excavation will be used as data for my thesis project and will be published as a thesis research document. Any information used from excavation on your property will be de-identified, meaning I will write about artifacts that will potentially come from your property, but I will not say that they came from your property specifically. They will be listed as having come from the project area. That being said, I may have to identify the location of the 1825 fort, and in this way your property may be identified as part of the location of the 1825 fort.

Finding archaeological evidence of the 1825 Fort Vancouver entails some potential effects. If an archaeological site is found on your property, that site will need to be registered with the Washington State Department of Archaeology and Historic Preservation (DAHP). This means that any future work on your property, such as home additions, tree removal, below surface utility work, etc., will require permitting from DAHP. It does not mean that your property will be taken from you, and it does not restrict you from doing what you want on your property. It just means you will need proper permits and possible archaeological monitoring during any ground disturbing activities.

Also, if archaeological excavation were to lead to identification of the first Fort Vancouver on your property you would have the voluntary choice to register the site as an historic place with the National Register of Historic Places, the Washington Heritage Register, and/or the Clark County Heritage Register. Registration may affect property value and property tax assessment, although it most often results in increased property value and reduced property taxes for a period of time. 
In the event that a decision is made to register with DAHP or the historic registers, I will offer assistance and support, and provide information about how to proceed with the process.

Your participation in the project is completely voluntary. You have the right to choose not to participate or to withdraw your participation at any point in this project. You will be provided a copy of this consent form for your records.

If you have any questions or complaints about this project, I will be glad to answer them at 503-XXX-XXXX or clearman@pdx.edu. You may also contact PSU's Office of Research Integrity at hsrrc@pdx.edu or 503-725-2227 with any questions or complaints.

If you agree to archaeological excavation on your property please sign below.

I am grateful for your valuable time and cooperation!

Date

Printed Name of Participant

Signature of Participant 


\section{Appendix M: Functional Typology}

\section{Functional Typology}

The following typology references artifacts found during this project. Following Sprague (1981), I list artifact types grouped by interpretive categories. Following the list, I describe diagnostic artifact types relevant to this project.

\begin{tabular}{|c|c|c|}
\hline $\begin{array}{c}\text { Functional Classification } \\
\text { (from Sprague) }\end{array}$ & Artifact type & $\begin{array}{l}\text { Probable date-range of } \\
\text { use in project area }\end{array}$ \\
\hline Domestic items & $\begin{array}{l}\text { Aluminum/Foil } \\
\text { Plastics/Styrofoam } \\
\text { Metal wire }\end{array}$ & $\begin{array}{l}\text { 20th century } \\
\text { 20th century } \\
\text { 20th century }\end{array}$ \\
\hline $\begin{array}{l}\text { Domestic items: yard } \\
\text { maintenance and } \\
\text { decoration }\end{array}$ & $\begin{array}{l}\text { Terra cotta flower pot } \\
\text { Landscape fabric }\end{array}$ & $\begin{array}{l}\text { 20th century } \\
\text { 20th century }\end{array}$ \\
\hline Domestic items: gustatory & 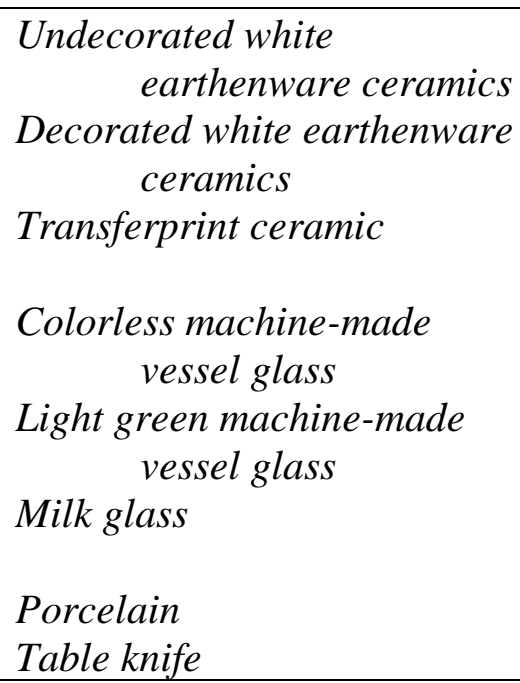 & $\begin{array}{c}\text { Early 19th century to } \\
\quad \text { present } \\
\text { 19th to 20th centuries } \\
\text { Early 19th century to } \\
\quad \text { present } \\
\text { 20th century } \\
\text { 20th century } \\
\text { Late 19th century to } \\
\text { present } \\
\text { 19th century to present } \\
\text { 20th century }\end{array}$ \\
\hline $\begin{array}{l}\text { Domestic items: decorative } \\
\text { or gustatory }\end{array}$ & Rockinghamware ceramic & $1830-1900$ \\
\hline $\begin{array}{l}\text { Domestic items: household } \\
\text { pastimes }\end{array}$ & $\begin{array}{l}\text { Crayon wax } \\
\text { Glass marble }\end{array}$ & 20th century \\
\hline Domestic items: laundry & Clothespin spring & 20th century \\
\hline $\begin{array}{l}\text { Domestic items: gustatory } \\
\text { OR pet maintenance }\end{array}$ & Animal bone & Unknown \\
\hline
\end{tabular}




\begin{tabular}{|c|c|c|}
\hline $\begin{array}{l}\text { Domestic items: } \\
\text { illumination }\end{array}$ & $\begin{array}{l}\text { Thin colorless glass: lamp or } \\
\text { lightbulb glass }\end{array}$ & 19th to 20th centuries \\
\hline Personal items: clothing & Metal fasteners & 19th to 20th centuries \\
\hline Personal items: adornment & $\begin{array}{l}\text { Orange glass seed bead } \\
\text { Orange plastic bead }\end{array}$ & $\begin{array}{c}\text { Early 19th century to } \\
\text { present } \\
\text { 20th century }\end{array}$ \\
\hline $\begin{array}{l}\text { Personal items: } \\
\text { indulgences }\end{array}$ & $\begin{array}{l}\text { Amber machine-made alcohol } \\
\text { bottle glass } \\
\text { Amber blown-into-mold } \\
\text { alcohol bottle glass } \\
\text { Dark olive blown-into-mold } \\
\text { alcohol bottle glass } \\
\text { Olive machine-made vessel } \\
\text { glass }\end{array}$ & $\begin{array}{l}\text { 20th century } \\
\text { 19th century } \\
\text { Early 19th century to } \\
1890 \\
\text { 20th century }\end{array}$ \\
\hline $\begin{array}{l}\text { Architecture: construction } \\
\text { materials }\end{array}$ & $\begin{array}{l}\text { American brick } \\
\text { Wooden boards } \\
\text { Aqua window glass } \\
\text { Colorless window glass } \\
\text { Composite roof tiles } \\
\text { Concrete }\end{array}$ & $\begin{array}{l}\text { 1840s to present } \\
\text { Unknown } \\
1850 \text { to present } \\
\text { 19th century to present } \\
\text { 20th century } \\
\text { 20th century }\end{array}$ \\
\hline $\begin{array}{l}\text { Architecture: construction } \\
\text { hardware }\end{array}$ & $\begin{array}{l}\text { American machine-cut nails } \\
\text { Wire nails }\end{array}$ & $\begin{array}{l}\text { 1840s to present } \\
20 \text { th century }\end{array}$ \\
\hline Architecture: plumbing & Metal plumbing pipe shaft & 20th century \\
\hline Architecture: electrical & $\begin{array}{l}\text { Metal object with plastic } \\
\text { prong }\end{array}$ & 20th century \\
\hline $\begin{array}{l}\text { Personal items: body ritual } \\
\text { and grooming OR } \\
\text { Domestic items: gustatory }\end{array}$ & $\begin{array}{l}\text { Amethyst machine-made } \\
\text { vessel glass } \\
\text { Aqua blown-into-mold vessel } \\
\text { glass } \\
\text { Aqua machine-made vessel } \\
\text { glass }\end{array}$ & $\begin{array}{l}1905 \text { to } 1930 \mathrm{~s} \\
\text { Early 19th to mid-20th } \\
\quad \text { centuries } \\
\text { 20th century }\end{array}$ \\
\hline $\begin{array}{l}\text { Personal and domestic } \\
\text { transportation }\end{array}$ & Asphalt & 20th century \\
\hline $\begin{array}{l}\text { Commerce and industry: } \\
\text { mining and quarrying }\end{array}$ & Coal & 19th to 20th centuries \\
\hline Unknown & Paper & Unknown \\
\hline Precontact items & $\begin{array}{l}\text { Projectile point } \\
\text { Fire cracked rock }\end{array}$ & $\begin{array}{l}\text { Precontact } \\
\text { Unknown }\end{array}$ \\
\hline
\end{tabular}




\section{Diagnostic Artifact Types}

The following list contains diagnostic artifact types and brief descriptions of their features, modes of manufacture, and/or pertinent historical information. These items are referenced in the main body of the text and warrant further explanation.

- Amethyst glass: From the 1880 s to the 1930 s, glassmakers commonly added manganese to glass ingredients to eliminate the glass' natural aqua color and produce colorless glass. When this manganese-infused glass is exposed to ultraviolet light over time it turns a light-purple, or amethyst, color (Lockhart 2006).

- Blown-into-mold vessel glass: A step beyond free-blown glass, blown-into-mold vessels requires a glass blower to blow the hot glass into a mold, with the glass taking the shape of that mold. This technique was used from the early 19th century to the mid-20th century (Society for Historical Archaeology 2018). Fragments found archaeologically might bear the striations, or "stretch marks" of bottle neck sherds, created as the glass blower stretched the neck into a relatively long and thin shape. Other fragments might display an "orange peel" effect of the body of the vessel.

- Machine-cut nails: In the 1790s, cut nails were invented, in which a sheet of iron was cut into wedge- shaped nails with the nail head hand-applied by a blacksmith (Nelson 1968). Crude machine-made heads began to be applied in the United States in the early 19th century, and by the late 1830s machine-made heads were perfected. Early American machine-cut nails cannot be distinguished from cut 
nails made today (Nelson 1968). Prior to the invention of cut nails, nails were hand-wrought by a blacksmith and displayed a characteristic hammered look with small indentations. American machine-cut nails were not available at Fort Vancouver until the 1840s, so any nails associated with the first fort would have been hand-wrought.

- American brick: American brick is a common type of brick found at Fort Vancouver in post-1840 HBC deposits and in U.S. Army deposits. These bricks are light red to reddish gray in color, and are distinguishable from English bricks, also found in HBC deposits at Fort Vancouver. English brick is yellow to pale brown on the surface and reddish brown to gray and purple-black in the interior, often found with inclusions coal, shell, and small pebbles (Wilson et al. 2011:26).

- Fire cracked rock $(F C R)$ : FCR is rock that has cracked and discolored from exposure to high heat such as from naturally-occurring or human-generated fire, such as from prairie burning, hearths, or camas ovens (Wilson et al. 2011:49).

\section{References}

Lockhart, Bill

2006 The Color Purple: Dating Solarized Amethyst Container Glass. Historical Archaeology 40(2):45-56.

Nelson, Lee H.

1968 American Association for State and Local History, Technical Leaflet 48: Nail Chronology as an Aid to Dating Old Buildings. History News 24(11).

Society for Historical Archaeology

2018 Historic Glass Bottle Identification and Information Website. Society for Historical Archaeology, Germantown, MD <https://sha.org/bottle/index.htm>. Accessed 19 August 2018. 
Wilson, Douglas C., Robert Cromwell, Danielle Gembala, Theresa Langford, Heidi

Pierson, and Debra Semrau

2011 Archaeology Lab Manual, 3rd Edition. Manuscript, Fort Vancouver National Historic Site, Vancouver, WA. 


\section{Appendix N: Survey 1 Results}

\section{Section 1: Demographics}

Question 1: Age group (Circle one)

18-29: (1) $3.2 \%$

30-49: (9) $29.0 \%$

50-69: (12) $38.7 \%$

70+: (9) $29.0 \%$

Question 2: Do you live in Vancouver, Washington?

Yes: (24) $77.4 \%$

No: (7) $22.6 \%$

Question 3: If yes, do you live in either the Hudson's Bay Neighborhood or the

Edgewood Park Neighborhood?

Yes: (11) $35.5 \%$

No: (12) $38.7 \%$

N/A: (8) $25.8 \%$

Question 4: Have you ever visited Fort Vancouver National Historic Site?

Yes: (31) $100 \%$

No: (0) $0 \%$

Question 5: Did you ever hear about the first Fort Vancouver before this meeting?

Yes: (27) $87.1 \%$

No: (4) $12.9 \%$

\section{Section 2: Heritage}

Question 6: What comes to mind when you think of heritage? List approximately 3 words or phrases.

- Legacy, Richness, Continuity

- History, a personal connection (linked, connected to something), a treasure trove of information

- Local history, American history, my roots

- Culture, history/the past, traditions, passed down/shared

- National, History, Ethnicity

- Ancestors, national history, stories

- What is inherited, what our ancestors passed down to us, a gift to us

- History of a time and place as it pertains to a person 
- Ancestry, place, time

- Culture, history, values, what makes up who we are.

- History

- Tradition, ancestry

- Preservation of cultures i.e. the way our ancestors lived

- Family history, local history

- History, family

- History, culture, stories

- We all have a heritage. We don't all know our heritage

- Founding fathers

- History, connection to the past, connection to the future

- The knowledge of those that came before

- Culture, family, history

- History, culture, home

- History of the people who came before us.

- What you learn from the people who came before us

- Nuts and bolts timeline of what has occurred. Known proven facts. What precedes us

- Knowing the past, learning from it.

- History, tradition, preservation

- Culture, history, legacy

- History, culture, Native Americans

Question 7: Do you think heritage is important in your community?

Yes (28) $90.3 \%$

No (2) $6.4 \%$

No answer (1) $3.2 \%$

If yes, in what ways?

- I live in a very historic neighborhood which I have thoroughly studied, shared with students, residents, others; continue to learn more about where I live.

- I feel more connected to an area if I know the early history in detail

- It creates a sense of connection to the community- the people who lived there and/or events that happened there. It answers questions like "how and where do I fit into all this?"

- Relationships between First Nations and Europeans. Relationship between the land and people

- My ancestors settled here in 1845 . It is interesting to learn what the area was like then. 
- It connects people to places through time. It helps folks understand where we have lived comes from where we are going

- We have to understand what and where we came from in order to understand who and why are and what we are today. If we don't understand what shaped our values, how can we pass them on to future generations?

- Hudson's Bay history represents an interesting intersection of American, British, and First Peoples history

- I'm a historian with archaeological experience, and an adjunct instructor of history

- Tells about the land we live on, the people that lived here. The art and artifacts are my favorite.

- Provides residents- long time and more recent- with connection to past and to each other

- Connects present names/features to past events, uses and people

- To know our history

- Creates a sense of place, a common bond. Knows what was here before. Leads to thoughts of preservation and what do we want it to be like in the future.

- Provides an anchor, or connection. Provides lessons already learned.

- It helps to preserve our community history

- To have a sense of history is to feel like you belong

- To understand where you are- need to understand the past

- Try not to make the same mistakes!

- Because of our important historical locations/figures

- Each generation and those to be should know. Learn from the good and bad. Be willing to share.

- History, tradition, preservation

- Provides perspective and connection

- Informs of what came before us

If no, why not?

- I personally think heritage ought to be part of existence everywhere, but I don't get a sense that it plays a major role in the public consciousness where I live

- People want new homes, which are built in areas rich in heritage, but the homes erase this

\section{Section: Archaeology}

Question 8: What comes to mind when you think of archaeology? List approximately 3 words or phrases

- Adventure, fascination, fun playing in the dirt (I am biased by being an archaeologist) 
- Items left under the ground from previous times in a controlled way

- Very old history. Our earliest ancestry.

- History, science, people

- Digging up the past. The history of the soil.

- Digging to look for signs of the history of the area

- Digging up the past! Research into past societies and cultures.

- Research involving excavation of artifacts to inform us as to past culture, animals, and plants

- Ancient or lost cultures and knowledge

- Indiana Jones! Actually my current area of interest is [shipwrecks]...so what else? We dig the past!

- Digging, artifacts, history, art

- Discovering and studying the tangible remnants of the history of a location

- Digging, research, sharing

- Digging, tools

- Digging up history

- The study of humanity in times past

- Distant history, laborious work of excavating, "forefathers"

- Study of items left by previous people/cultures

- Digging, science, innovation

- Searching for remnants, clues from the past

- History of culture, civilization

Question 9: Have you ever visited an archaeological site?

Yes (17) $54.8 \%$

No (5) $16.1 \%$

No answer (9) $29 \%$

Question 10: In what ways have you learned about archaeology?

TV (16)

Visiting a dig (15)

Books (11)

Magazines (10)

Websites (6)

College/University (4)

Volunteering (3)

Private study, exploration (2)

Employment (2)

Oregon Archaeological Society (2)

Media (1)

Museums (1) 
Movies (1)

Question 11: Do you think archaeology is important to your life personally?

Yes (22) $71 \%, 100 \%$ of responses

No (0)

No answer (9) $29 \%$

If yes, in what ways?

- History is like an unlimited account of knowledge I can draw on anytime, for solution or inspiration.

- My passion is history and knowing the details make me feel connected.

- It confirms our stories and history

- It's important to me to find traces of history before even more is lost

- I am very interested in history. I come from Europe where the past is much more visibly part of present-day life, e.g. older buildings and historical sites still in use.

- Provides evidence that confirms or contradicts the written sources and can help us have hands-on understanding of life in the past.

- We learn about history

- Provides interesting insights into the past

- Volunteer and travel- gives a better connection and perspective

- The work done in France on the WWI battlefields has helped me have a better understanding of what my grandfather experienced during the war.

- Understanding our evolution, history, and cultural history

- We learn things from our ancestors we never knew

- It helps to understand our and others roots

- Increased knowledge

- Knowing more about the world you live in is important

- Promote science, understand history

- Visited several in many places in the world

- Learning about cultural evolution

- I find it fascinating

Question 12: Is archaeology important to society?

Yes (21) $67.7 \%, 100 \%$ of submitted answers

No $(0)$

No answer (10) $32.3 \%$

If yes, why? 
- I think it is important because the physical reality of our past has built the civilization we depend on. That impact can even transcend the fact that most people may never be aware of archaeology's importance.

- We need to know who we are and appreciate what our ancestors experienced.

- It confirms our stories and history

- Knowledge of how people lived before us is valuable

- It helps us understand past cultures and fill in bits of pre-history

- Well, I'm highly biased!

- Provides interesting insights into the past

- Keeps a perspective on our past

- I find it fascinating that the past isn't so different than the present

- Helps society to think about how we came to be and also helps to provide perspective on other societies in the past, both commonalities and differences

- More than science

- Increased knowledge

- There is no future if you don't study the past

- Learn from where we've been

- Reminds of the optimistic forces that bring us into the future

- Respect of past cultures, guide to the future 


\section{Appendix O: Survey 2 Results}

\section{Section 1: Demographics}

Question 1: Age group (Circle one)

18-29: (1) $3 \%$

30-49: (5) $17 \%$

50-69: (10) $34 \%$

70+: (13) $45 \%$

Question 2: Do you live in Vancouver, Washington?

Yes: (22) $76 \%$

No: (6) $21 \%$

No answer: (1) $3 \%$

Question 3: If yes, do you live in the Hudson's Bay or Edgewood Park neighborhood?

Yes: $10 \%(3)$

No: $86 \%(25)$

No answer: $3 \%(1)$

Question 4: Have you ever visited Fort Vancouver National Historic Site?

Yes: $97 \%(28)$

No: $3 \%(1)$

Question 5: Did you ever hear about the first Fort Vancouver before this meeting?

Yes: $79 \%(23)$

No: $21 \%(6)$

\section{Section 2: Heritage}

Question 6: What comes to mind when you think of heritage? List approximately 3 words or phrases.

- History, Ancestors

- Background, historical, legacy

- History, Family, Heirlooms, People

- History, culture, answers to why we do the things the way we do

- Your family history

- Passing on family history

- Sites, nature, heritage, cultural

- Old, collectables, ancient

- Family of humankind

- Tradition, link between generations, knowledge of the past to build on 
- Origins, history, native

- History

- Genealogy, longevity, history

- Connections to the past - a history

- Our past culture, our inheritance, our customs

- Past, richness of stories, linking truth to stories passed down

- Collective history and ancestry

- History, traditions, family

- History, knowledge

- Positive history of our community

- History, responsibility, respect

- My roots, history, culture

- local history, change, heritage changes with each generation

- That which is passed down to future generations, property passed on to others

- Origins, history, reasons for modern situations

- Family, stories, pictures, my Indian heritage

- Cultural transfusion, genealogy, and area history

Question 7: Do you think heritage is important in your community?

Yes: $97 \%$ (28)

No: 0

No answer: $3 \%$ (1)

If yes, in what ways?

- It helps build a feeling of community and gives one pride

- Heritage lets present and future residents feel/know that they are who they are and that they connect to their past and hopefully create memories/history for future generations

- Knowing the past can enlighten the future

- We have deep roots here and there are several organizations that provide local history education

- Celebrating our community and ancestors past accomplishments

- Heritage/history are important to be able to understand where we came from and how the area was settled

- Preserve and make known what was found and how it was used

- Understand our importance of our place in history

- Historical guide posts, tourism dollars, appreciation for what people achieved so we can have what we have, children need to understand the past 
- History has so much to offer. Learning from our mistakes, creating new ideas. Knowing where we came from

- It provides a context for the character of the community

- It contributes to personal and community identity. It enriches who we are as a people. Important to pass heritage to future generations

- Many extended families remain in the area - (none of ours)

- It is a reflection of our inherited values

- It often molds the present

- It's very important to know one's history and origins

- It's important to know about your heritage. Let's you learn from past

- I live at the heart of local history. Have my own little collection of artifacts while building 2 new old-style homes blocks away for the fort. Had thirst to learn everything historic

- Proud history, culture, quality of life

- It has been what defines this area and needs to be preserved through education

- Taking care of the history and culture

- Provide historic perspective, tourism opportunities

- It is important to know where we came from, how we got here

- Our community was established generations ago making those who live here an integral part of the history of the Pacific Northwest

- Entertainment, perspective

- History, generations, how we can learn from the past, how hard it was for our ancestors

- It helps connect to our local community in a deeper sense

If no, why not?

- Community-wide I don't think there is an appreciation for our history

\section{Section 3: Archaeology}

Question 8: What comes to mind when you think of archaeology? List approximately 3 words or phrases.

- History

- Investigating historical sites for artifacts to tell the story of the original "owners"

- Digging, History, Artifacts from previous cultures

- The study of artifacts from earlier cultures

- Discovering key aspects of how people lived

- Finding cultural/historical artifacts and understanding their context in the natural environment 
- Excavating and carefully uncovering old artifacts or evidence thereof

- Systematic study of culture through the lens of artifacts

- History, understanding the past

- Exploring the past with historic objects

- Everyday history of peoples, animals, and places

- Research-driven - people who know what they're doing and have a knowledge and respect for their discoveries

- Our physical and cultural history associated with bits and pieces of our past

- Wonderful, important, exciting even when counting broken pieces of clay pipe stems

- Looking for artifacts from the past to learn how people lived

- Artifacts, process of recovering aged items, took some archaeology in college, many anthropology classes

- Uncovering, discovering the past

- Our beginnings and history of this region

- History of past cultures

- Artifacts, excavations, museums

- History, past, future

- A view into our past where artifacts and structures using science can give us a more definite answers about our past and who we are and come from.

Question 9: Do you think archaeology is important to your life personally?

Yes: $69 \%(20)$

No: $3 \%$ (1)

No answer: $28 \%(8)$

If yes, in what ways?

- Helps illustrate history

- I've always been interested in it. It helps us know more about our background

- Assuage my curiosity

- I enjoy learning about it

- My genealogy goes back to $720 \mathrm{AD}$ and well-documented. Many are not, however my family influenced many events in history

- Gives people an understanding of historical events that have taken place

- I am a land surveyor and routinely search for original survey marks and monuments first established from 1851 to 1900

- I love it

- Historical context

- Verifies history 
- Artifacts help tell the story of earlier people. My great-great-grandfather crossed Oregon Trail in covered wagon and settled in country in 1867

- I appreciate all the work involved and the knowledge that's shared

- It's extremely interesting and provides a map and timetable of our past

- Fills in the details

- I love to learn about the past and how people lived in the past

- Artifacts, process of recovering aged items, took some archaeology in college, many anthropology classes

- Uncovering, discovering the past

- Knowledge

- I'd say it is important to me primarily because I find it interesting. Primarily as it relates to how and what humans are capable of

- It tells me how our past effects can affect us now, teaches how we worked to where we are now, makes us understand our heritage

- Went to school for it but never obtained a career in it

If no, why not?

- It isn't something I am personally involved in

Question 10: Is archaeology important to society?

Yes: $76 \%(22)$

No: (0)

No answer: $24 \%(7)$

If yes, why?

- It explains where things came from and how they got the way they are. It tells the story.

- Who we are is based on our past

- Explains our past

- It helps us learn more about how earlier cultures lived

- To preserve remnants of our past

- Understanding the history and where we have come from

- We need to understand how those that came before us dealt with their existence in earlier

- Understand, preserve, communicate

- Understanding the past contributes to the present

- Verifies history

- Artifacts help tell the story of earlier people. My great-great-grandfather crossed Oregon Trail in covered wagon and settled in country in 1867 
- It provides a history and basis for where we are now

- Portrayal of past values and how our society has changed

- Fills in the blanks

- People need to understand how life was. It allows you to understand where we came from and to appreciate life

- To learn about our past. Volunteered in Fort's state of the art archive building sorting pieces of beaver traps and old nails

- Uncovering, discovering the past

- Knowledge

- Archaeology gives us a longer-term perspective on civilizations and how they grow/cycle and collapse

- It not only tells us about the past but can answer questions about the future and present

\section{Section 4: Changes in feelings and attitudes}

Question 11: Did you know about this project before tonight?

Yes: $45 \%$ (13)

No: $38 \%(11)$

No answer: $17 \%(5)$

Question 12: Did the project change how you feel about heritage and archaeology?

Yes: $14 \%(4)$

No: $45 \%$ (13)

No answer: $41 \%$ (12)

If yes, why?

- I'm surprised that evidence still remains of those earlier times

- It feels very close to home

- Just makes it more concrete why we need people like you out there finding and exploring our history

- Not really

- It added to my intrigue about the original fort

If no, why not?

- I've always felt strongly about those

- I have been interested since I have ancestors who worked for the Hudson's Bay Company at Fort Vancouver

- My feelings have not changed as this is important in understanding the history of the site that has been under great change over the years 
- I already knew it was important to make the connection

- I think it's important

- I'm just thrilled to know that a young person (and a woman!) is interested in carrying on this tradition

- Because of its importance in satisfying my curiosity and my interest in our inherited values and culture

- Already interested

- I have always appreciated archaeology and have always loved learning how the past was lived

- We want to see the sign on Grand Blvd made accurate

- But it is important to us

- Because my beliefs on history are the same, our history helps us learn, our past and helps our future

- Love history

What comes to mind when you think of heritage?

\begin{tabular}{|l|c|l|c|}
\hline \multicolumn{1}{c|}{$\begin{array}{c}\text { Survey 1 } \\
\text { Response categories }\end{array}$} & $\begin{array}{c}\text { Number of } \\
\text { responses }\end{array}$ & \multicolumn{1}{c|}{$\begin{array}{c}\text { Survey 2 } \\
\text { Response categories }\end{array}$} & $\begin{array}{c}\text { Number of } \\
\text { responses }\end{array}$ \\
\cline { 2 - 4 } History & 17 & History & 18 \\
\hline Culture/tradition & 15 & Culture/tradition & 16 \\
\hline Ancestry & 13 & Ancestry & 12 \\
\hline Time (past/future) & 13 & Time (past/future) & 8 \\
\hline Personal connection & 12 & Personal connection & 7 \\
\hline Knowledge/information & 10 & Knowledge/information & 5 \\
\hline National significance & 5 & Artifacts & 4 \\
\hline Place & 5 & Community/local & 4 \\
\hline Preservation & 2 & Preservation & 3 \\
\hline Native Americans & 1 & Informs the present & 3 \\
\hline Community/local & 1 & Native Americans & 2 \\
\hline & & Nature & 1 \\
\hline
\end{tabular}

Is heritage important in your community?

\begin{tabular}{|l|c|l|c|}
\hline \multicolumn{1}{|c|}{$\begin{array}{c}\text { Survey 1 } \\
\text { Response categories }\end{array}$} & $\begin{array}{c}\text { Number of } \\
\text { responses }\end{array}$ & \multicolumn{1}{c|}{$\begin{array}{c}\text { Survey 2 } \\
\text { Response categories }\end{array}$} & $\begin{array}{c}\text { Number of } \\
\text { responses }\end{array}$ \\
\cline { 2 - 4 } Knowledge/understanding & 15 & Informs the present/future & 13 \\
\hline Illustrates history & 13 & Illustrates history & 9 \\
\hline Personal connections & 11 & Knowledge/understanding & 8 \\
\hline Community/local connections & 8 & Community/local connections & 8 \\
\hline Connections across time & 7 & Community pride/appreciation & 7 \\
\hline
\end{tabular}




\begin{tabular}{|l|l|l|c|}
\hline Place/landscape & 6 & Connections across time & 5 \\
\hline Native Americans & 2 & Preservation & 4 \\
\hline Preservation & 2 & Personal connections & 4 \\
\hline Ancestors & 1 & Ancestors & 3 \\
\hline Artifacts & 1 & Tourism & 3 \\
\hline & & Community identity & 3 \\
\hline & & Culture & 2 \\
\hline & & Artifacts & 1 \\
\hline & & Personal identity & 1 \\
\hline & & Improves quality of life & 1 \\
\hline
\end{tabular}

What comes to mind when you think of archaeology?

\begin{tabular}{|l|c|l|c|}
\hline \multicolumn{1}{|c|}{$\begin{array}{c}\text { Survey 1 } \\
\text { Response categories }\end{array}$} & $\begin{array}{c}\text { Number of } \\
\text { responses }\end{array}$ & \multicolumn{1}{c|}{$\begin{array}{c}\text { Survey 2 } \\
\text { Response categories }\end{array}$} & $\begin{array}{c}\text { Number of } \\
\text { responses }\end{array}$ \\
\hline History & 19 & Artifacts & 12 \\
\hline Excavation/digging & 13 & Tells the story of the past & 12 \\
\hline People/culture & 10 & People/culture & 10 \\
\hline Research/study & 7 & History & 9 \\
\hline Artifacts & 7 & Excavation/digging & 5 \\
\hline Knowledge/understanding & 3 & Research/study & 5 \\
\hline Science & 3 & Knowledge/understanding & 2 \\
\hline Sites & 2 & Science & 2 \\
\hline Tells the story of the past & 2 & Sites & 2 \\
\hline Nature & 1 & Nature & 2 \\
\hline Indiana Jones & 1 & Excitement & 1 \\
\hline Interesting & 1 & Employment & 1 \\
\hline Education & 1 & Education & 1 \\
\hline Art & 1 & Local history & \\
\hline Shipwrecks & 1 & Museums & \\
\hline Excitement & 1 & & \\
\hline Employment & 1 & & \\
\hline
\end{tabular}

